\title{
Uruguay: Fifth Review Under the Stand-By Arrangement and Requests for Modification of the Arrangement and Waiver of Nonobservance and Applicability of Performance Criteria- Staff Report; Staff Supplement; Press Release on the Executive Board Discussion; and Statement by the Executive Director for Uruguay
}

In the context of the fifth review under the Stand-By Arrangement and requests for modification of the Arrangement and waiver of nonobservance and applicability of performance criteria with Uruguay, the following documents have been released and are included in this package:

- the staff report for the fifth review under the Stand-By Arrangement and requests for modification of the Arrangement and waiver of nonobservance and applicability of performance criteria, prepared by a staff team of the IMF, following discussions that ended on May 21, 2004, with the officials of Uruguay on economic developments and policies. Based on information available at the time of these discussions, the staff report was completed on August 13, 2004. The views expressed in the staff report are those of the staff team and do not necessarily reflect the views of the Executive Board of the IMF.

- a staff supplement of August 25, 2004 updating information on recent developments.

- a Press Release summarizing the views of the Executive Board as expressed during its August 27, 2004 discussion of the staff report that completed the review and requests.

- a statement by the Executive Director for Uruguay.

The documents listed below have been separately released.

Letter of Intent sent to the IMF by the authorities of Uruguay*

Memorandum of Economic and Financial Policies by the authorities of Uruguay*

Technical Memorandum of Understanding*

* May also be included in the Staff Report.

The policy of publication of staff reports and other documents allows for the deletion of market-sensitive information.

To assist the IMF in evaluating the publication policy, reader comments are invited and may be sent by e-mail to publicationpolicy@imf.org.

Copies of this report are available to the public from

International Monetary Fund • Publication Services

$70019^{\text {th }}$ Street, N.W. • Washington, D.C. 20431

Telephone: (202) 623-7430 • Telefax: (202) 623-7201

E-mail: publications@imf.org •Internet: http://www.imf.org

Price: $\$ 15.00$ a copy

International Monetary Fund

Washington, D.C. 

INTERNATIONAL MONETARY FUND

\title{
URUGUAY
}

\section{Fifth Review Under the Stand-By Arrangement and Requests for Modification of the Arrangement and Waiver of Nonobservance and Applicability of Performance Criteria}

\author{
Prepared by the Western Hemisphere Department \\ (In collaboration with other Departments) \\ Approved by Markus Rodlauer and Liam P. Ebrill
}

August 13, 2004

\begin{abstract}
Stand-By Arrangement. The current arrangement (SDR 2,128.3 million, 694.4 percent of quota) runs through March 2005. SDR 559.2 million remains to be disbursed, and a purchase of SDR 139.8 million will become available upon completion of this review. On February 20, 2004, the Executive Board concluded the fourth review, five months behind schedule. Directors welcomed the recovery of the economy but expressed concern at the slow pace of banking and other structural reforms.
\end{abstract}

Economic developments. The economic recovery is stronger than expected, and inflation has fallen to 10 percent (with core inflation in single digits). Indicators of financial and banking sector soundness continue to recover. While these developments have reduced near-term program risks, important vulnerabilities persist, leaving little room for policy slippage.

Review. Discussions focused on implementation of the fiscal and monetary program; pending steps to strengthen the banking system; and prospects for other key structural reforms.

Program status. The macroeconomic framework remains on track, and a new effort is being made at this review to accelerate (delayed) banking sector reforms, but progress in other structural reforms has been mostly disappointing. End-June quantitative performance criteria (PCs) for NIR, NDA, and general government noninterest expenditure were observed, as were the end-March PCs on the public sector primary surplus and public sector debt, but there have been delays in the restructuring of public banks and asset disposal of liquidated banks.

Access and phasing. In light of the strengthened external position and the delays with this review, the authorities are requesting a reduction in total access (by SDR 139.8 million, 45.6 percent of quota) and a rephasing of the remaining purchases.

Mission. Discussions were held in Montevideo during May 10-21. The mission met with Minister of Economy and Finance Alfie, Central Bank President de Brun, Budget Director Davrieux, other senior officials, representatives of the bank employees' union and the private sector, and the economic advisors of the presidential candidates. The staff team comprised A.Wolfe (Head), O. Adedeji, and H. Ma (all WHD), J. Kozack (PDR), and E. Ley (FAD). An MFD team (C. Lee and S. Seelig) overlapped with the mission, which was also assisted by A. Bauer (Resident Representative). G. Le Fort (Executive Director) and D. Vogel (OED) participated in some of the meetings.

Publication. In line with the new exceptional access guidelines, the authorities have consented to the publication of this report. 
Contents

Page

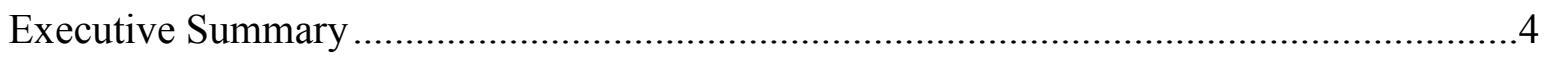

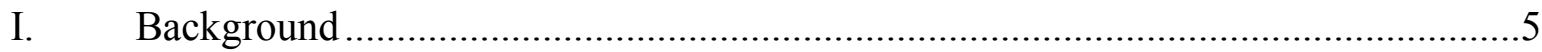

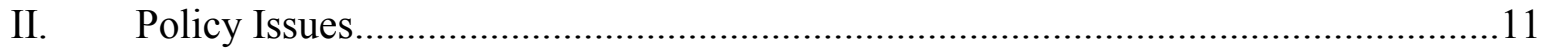

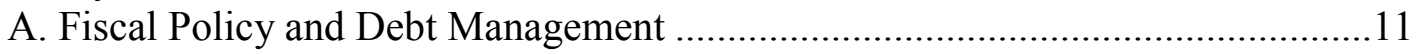

B. Monetary and Exchange Rate Policies ........................................................ 14

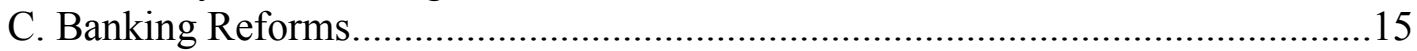

III. Vulnerabilities and Program Risks ............................................................. 19

IV. Program Financing, Monitoring, and Safeguards .........................................2 21

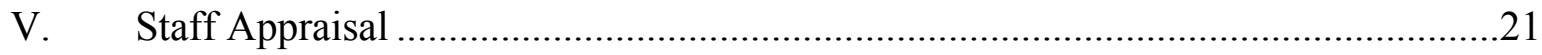

Boxes

1. Election Modalities and Outlook ......................................................................5

2. Fiscal Implications of the Regional Energy Shortage and

Higher World Oil Prices ..................................................................................... 12

3. Bank Liquidation Funds.................................................................................. 16

4. Progress under BROU's Restructuring Plan......................................................18

5. Public Debt Sustainability Analysis...............................................................20

Figures

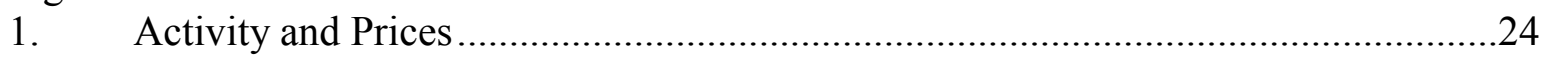

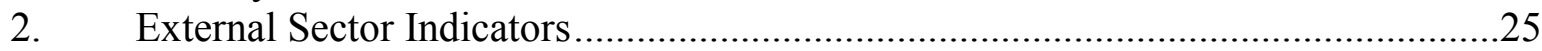

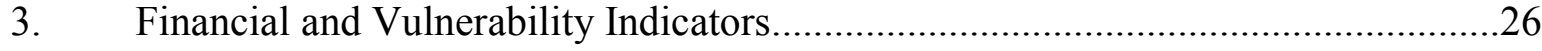

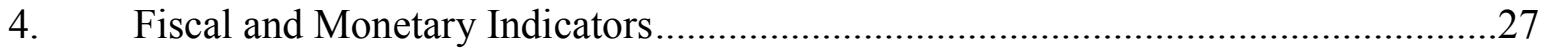

\section{Tables}

1. Selected Economic and Financial Indicators ..............................................28

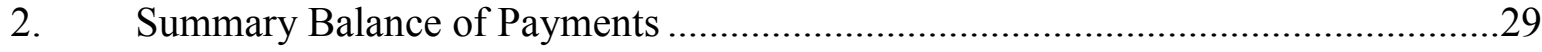

3. Performance Under the 2004 Economic Program ................................................30

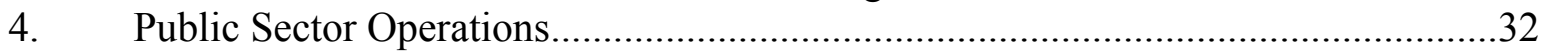

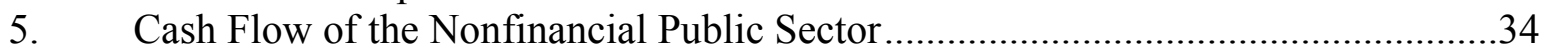

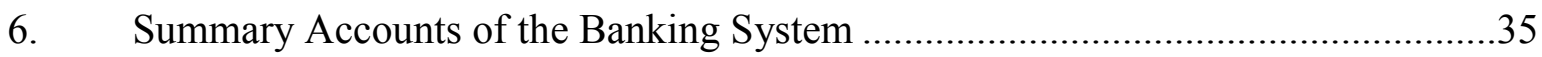

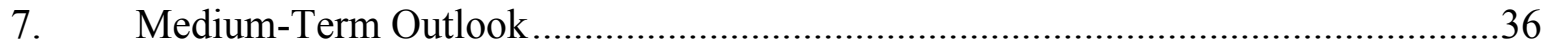

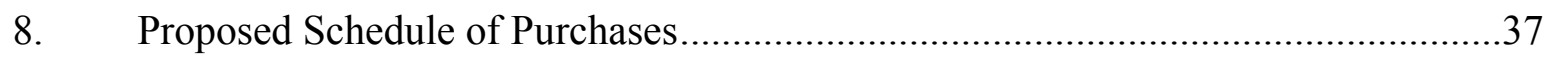


9. Projected Payments to the Fund and Indicators of Capacity

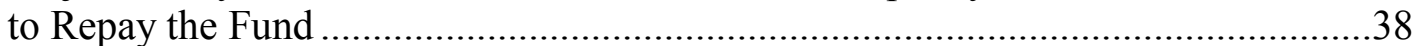

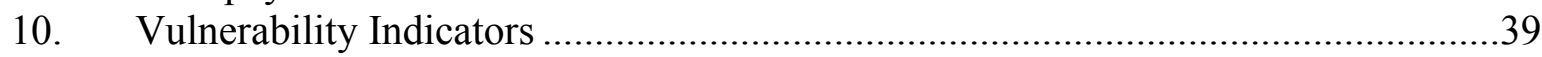

Appendices

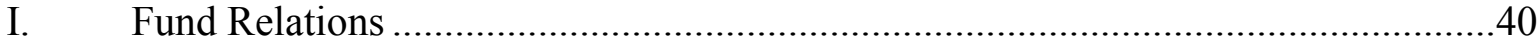

II. Relations with the World Bank Group.................................................................42

III. Relations with the Inter-American Development Bank ............................................44

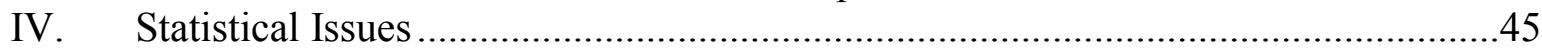

V. Public Debt Sustainability Analysis...................................................................48

Attachments

I. Letter of Intent and Supplement to the Memorandum of Economic

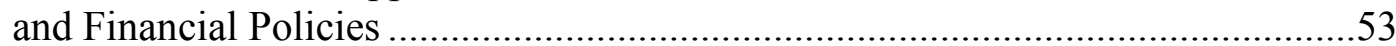

II. Technical Memorandum of Understanding ...........................................................63 


\section{EXECUTIVE SUMMARY}

\section{Background}

Uruguay's recent recovery from its long recession has been faster than expected, reflecting implementation of prudent policies and a favorable external environment. Since bottoming out at end-2002, growth has accelerated, unemployment has declined, and inflation has fallen to 10 percent (with core inflation in single digits). Financial indicators have mostly improved since the last review, and the exchange rate has been relatively stable. Nonetheless, the economy remains vulnerable from the high public debt, including a significant short-term component, and the still fragile banking system.

The macro framework is broadly on track, but progress with structural reform remains uneven. Fiscal performance has been better than programmed, reflecting buoyant revenues, and the monetary and balance of payments targets of the program have been met. The restructuring of the public banks is now moving ahead, but little progress has been made on the disposal of assets of liquidated banks, and the government's proposals for tax reform and reform of the specialized pension funds have not been acted on by Congress.

\section{Policy discussions and staff appraisal}

- GDP growth is now forecast at 7 percent in 2004. Inflation at year's end is projected to be at the upper end of the BCU's target band of 7-9 percent. The net international reserve target under the program has been raised, in light of the strong overperformance with respect to the program target in the first half of the year.

- The primary surplus target for 2004 has also been raised, from 3.2 to 3.4 percent of GDP, reflecting the stronger-than-envisaged revenue performance. Spending remains restrained and public utility prices are being adjusted in line with operating costs. Achieving the primary surplus target will be key to foster market confidence and lay the basis for the required additional medium-term fiscal consolidation.

- The restructuring of the public banks is now moving forward, but the disposal of assets in the bank liquidation funds needs to be accelerated. Successful implementation of the program's bank restructuring strategy is essential to limit fiscal costs, strengthen creditor discipline, and help normalize credit conditions.

- While program risks have diminished further since the last review, important vulnerabilities remain, leaving no room for policy slippages. Public sector debt service will remain high for a significant period of time. 


\section{BACKGROUND}

\section{Political situation}

\section{The political environment is increasingly focused on the upcoming national} elections. Presidential and congressional elections will be held on October 31, 2004. Recent polls show a large lead — albeit somewhat reduced from earlier highs - for the opposition coalition led by the Frente Amplio (Box 1). The new government will take office on March 2, 2005; the current Stand-by Arrangement (SBA) expires March 31, 2005. Reflecting the elections, legislative work on economic reforms has slowed sharply, while proposals for additional expenditure have increased; so far, however, spending has been kept within program limits.

\section{Box 1: Election Modalities and Outlook}

A victory in the first round of the presidential elections requires a majority of all votes cast. If no candidate achieves such a majority in the first round (October 31), a runoff is held between the top two candidates. In the second round (November 28), a President is elected by a majority of all valid votes. Congressional seats are determined in the first round through proportional representation. The new president will take office on March 2. Also on October 31, a plebiscite will be held on whether to remove private participation in the processing and supply of potable water, similar to the December 2003 referendum on the recall of a law allowing the state oil company (ANCAP) to engage in partnerships with the private sector.

According to most opinion polls, the leftleaning Frente Amplio-led (FA) coalition enjoys a strong lead. However, its support has fallen slightly below 50 percent, raising the possibility of a second-round vote, which polls suggest could be a closely contested race between the FA and National Party candidates. The main presidential candidates are:

- FA. Dr. Tabaré Vázquez, former mayor of Montevideo and presidential candidate in 1994 and 1999 . His policy focus is on combating poverty and income redistribution. He favors an

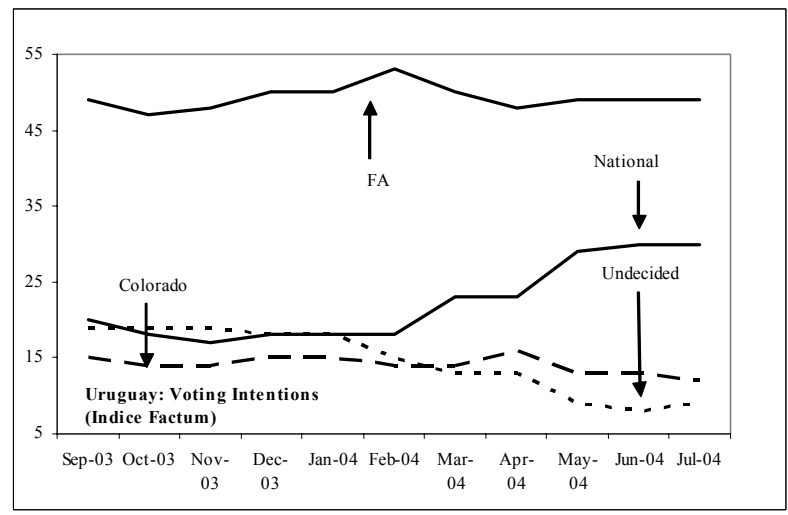
active role for the state in the economy to generate employment and promote strategic sectors, while maintaining macroeconomic stability and honoring debt commitments.

- National (Blanco) Party. Senator Jorge Larrañaga is running second in the polls. He supports a primary fiscal surplus of "no less than 3 percent of GDP" and maintaining single-digit inflation, while pursuing policies to promote domestic production and decentralization.

- Colorado Party. Mr. Guillermo Stirling, interior minister of the past two Colorado governments, has pledged to broadly continue the current economic policy approach, including macroeconomic stability and stable rules for investors, and advocates a strengthening of the social safety net. 


\section{Developments under the program}

2. The economic recovery is stronger than anticipated at the time of the last (fourth) review, supported by the favorable external environment.

- Growth and employment. Real GDP grew by $2 \frac{1}{2}$ percent in 2003 (compared with a previous estimate of 1 percent). First-quarter growth reached 14.3 percent $(y / y)$; private consumption and investment expanded strongly as the recovery has broadened beyond exports. Unemployment fell in June to 13.1 percent, almost $4 \frac{1}{2}$ percentage points lower than a year ago.

- Wages and inflation. Wage pressures

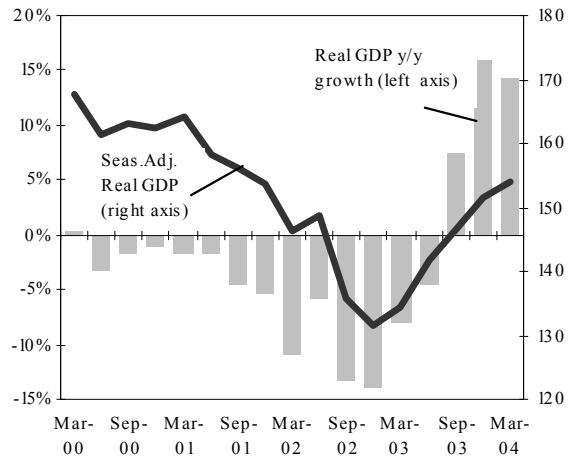
remain modest, with the 12-month increase in June at 8 percent. Inflation declined through the first quarter, but has picked up somewhat since to 10.2 percent in July (y/y), in part reflecting higher utility and petroleum product prices, and above the central bank's target range for end-2004 of 7-9 percent. Core inflation in July was 7.2 percent.

- External current account. The external current account surplus declined to 0.7 percent of GDP in 2003 mainly due to a spike in imports in the second half of the year and increased profit repatriation by foreign banks. During the first half of 2004, the current account posted a modest surplus as strong tourism and export earnings outpaced the rebound in imports.

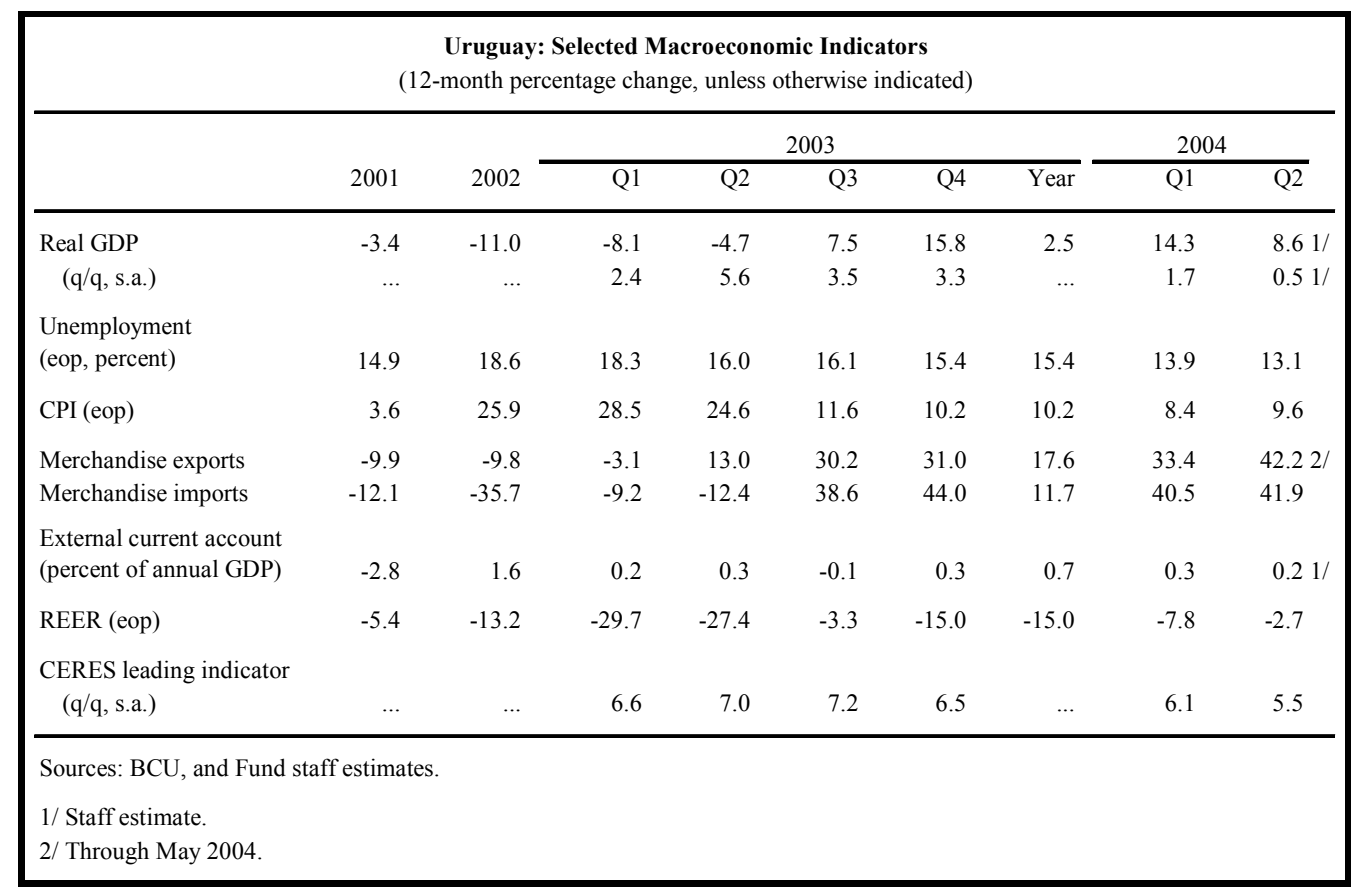


3. Most financial indicators have continued to improve.

- Exchange rate. Since end-2003, the peso has been fairly steady, with the BCU purchasing some US $\$ 100$ million through July in the foreign exchange market (in line with the program). Uruguay's real effective exchange rate remains some 30 percent more depreciated than its average in the run up to the financial crisis, and 15 percent more depreciated than its average during the 1990s.

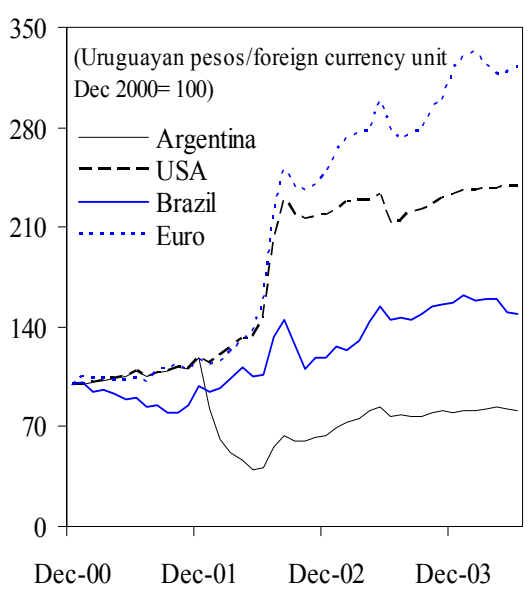

- International reserves. Gross international reserves of the BCU have been maintained in 2004. Gross reserves of the banking system cover almost 60 percent of short-term debt and dollar deposits (about the same as in Argentina, but lower than in Paraguay and Peru).

\begin{tabular}{|c|c|c|c|c|c|c|}
\hline \multicolumn{7}{|c|}{ Comparisons of Banking System Reserve Adequacy Indicators } \\
\hline & 1999 & 2000 & 2001 & 2002 & 2003 & $\begin{array}{l}\text { June } \\
2004\end{array}$ \\
\hline \multicolumn{7}{|l|}{ Argentina } \\
\hline Gross official reserves (US\$ million) & 27,300 & 26,900 & 14,900 & 10,476 & 14,100 & 18,200 \\
\hline Banks' gross foreign assets & 13,366 & 16,077 & 6,185 & 3,171 & 2,727 & 2,633 \\
\hline As $\%$ of ST debt + FX deposits & 48.9 & 44.2 & 24.9 & 46.8 & 47.9 & 58.1 \\
\hline \multicolumn{7}{|l|}{ Paraguay } \\
\hline Gross official reserves (US\$ million) & 988 & 772 & 723 & 641 & 982 & 982 \\
\hline Banks' gross foreign assets & 400 & 496 & 446 & 288 & 389 & 415 \\
\hline As $\%$ of ST debt + FX deposits & 76.3 & 64.9 & 60.1 & 60.9 & 82.4 & 76.8 \\
\hline \multicolumn{7}{|l|}{ Peru } \\
\hline Gross official reserves (US\$ million) & 9,003 & 8,562 & 8,838 & 9,690 & 10,206 & 11,066 \\
\hline Banks' gross foreign assets & 1,133 & 901 & 851 & 822 & 644 & 487 \\
\hline As $\%$ of ST debt + FX deposits & 61.4 & 63.9 & 62.2 & 74.1 & 77.2 & 79.2 \\
\hline \multicolumn{7}{|l|}{ Uruguay } \\
\hline Gross official reserves (US\$ million) & 2,602 & 2,779 & 3,099 & 776 & 2,087 & 2,244 \\
\hline Banks' gross foreign assets & 5,803 & 6,252 & 7,271 & 4,138 & 3,725 & 3,745 \\
\hline As $\%$ of ST debt + FX deposits & 59.0 & 59.2 & 60.3 & 48.5 & 59.6 & 57.8 \\
\hline
\end{tabular}

- Debt and sovereign spreads. In February, Uruguay reopened its three-year, pesodenominated, inflation-indexed global bond for US\$100 million at an interest rate 200 bps below the original issuance in October 2003; in July 2004, US $\$ 250$ million of 18-month peso-denominated notes were issued. ${ }^{1}$ Fitch and S\&P raised Uruguay's

\footnotetext{
${ }^{1}$ The notes have a minimum return guarantee equal to the depreciation of the peso relative to the U.S. dollar.
} 
foreign currency debt rating one notch to B, in March and July, respectively. Uruguay's sovereign spreads have widened somewhat since the first quarter, in line with those for other emerging market debt, and are now around 600 bps. The stock of total short-term public debt declined slightly through endJune to about 6 percent of GDP. ${ }^{2}$

- Domestic interest rates. Rates on peso- and dollar-denominated T-bills have increased

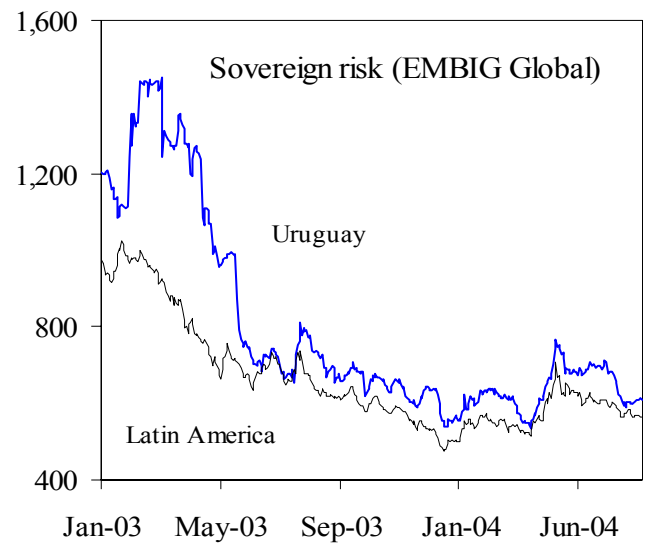
somewhat since end-2003, reflecting the increase in U.S. interest rates and the rise in Uruguay's sovereign risk premium. Interest rates on 6-month peso-denominated T-bills now stand at around 20 percent.

4. The monetary program is on track. Monetary policy was tightened in the first quarter and again in July. Early in the year, in view of elevated inflation expectations and measures of underlying inflation pointing to year-end inflation of almost 11 percent, the central bank (BCU) cut its quarterly (average) base money targets for 2004. At the same time, the BCU switched from a point target to a target range for base money to provide more flexibility in dealing with volatility in money demand. In July, base money targets were cut again when the BCU announced a target range of 6-8 percent for 12-month inflation through June 2005. The end-June PCs on NIR and NDA were observed with comfortable margins.

\section{Fiscal performance has been stronger than programmed owing to robust} revenue performance. The primary surplus of the consolidated public sector reached 1.1 percent of annual GDP in the first quarter, 0.6 percent of GDP higher than programmed, with a commensurate improvement in the overall deficit. The overperformance reflected better-than-expected revenue (0.6 percent of GDP), while expenditure was kept within the program limits and state-enterprise tariffs were adjusted in line with cost conditions. Preliminary second-quarter data indicate that revenue has continued to outperform the program, mainly due to buoyant corporate income tax receipts, and expenditure restraint has been maintained. In light of this performance, in May-July, the authorities eliminated emergency surcharges (on the wage tax and corporate income tax) and taxes (on commissions and public utilities), which will cost the budget about 0.5 percent of GDP in 2004 (1.4 percent of GDP on an annual basis). ${ }^{3}$

\footnotetext{
${ }^{2}$ The stock of peso-denominated T-bills, about one-third of total short-term debt, has a weighted average residual maturity of just two months, compared with nine months for dollar-denominated T-bills.

${ }^{3}$ These surcharges and taxes were introduced (on a temporary basis) during the financial crisis in 2002. At that time, the government was given the authority to unwind them taking into consideration the prospects for the achievement of the fiscal targets.
} 
6. Private sector deposits in the banking sector have continued to recover. Dollar deposits rose by US $\$ 463$ million during the first half of this year, rising further above their level in July 2002, when the bank holiday was declared. Bank credit has yet to revive, however, as banks continue to focus on cleaning their balance sheets. Moreover, dollarization remains high, with about 90 percent of deposits in dollars, despite measures introduced over the past year to reduce incentives for dollarization. ${ }^{4}$

\begin{tabular}{|c|c|c|c|c|c|c|c|c|c|}
\hline \multicolumn{10}{|c|}{ Uruguay: Changes in Deposits } \\
\hline & \multicolumn{3}{|c|}{2002} & \multicolumn{4}{|c|}{2003} & \multicolumn{2}{|c|}{2004} \\
\hline & \multicolumn{2}{|c|}{ Jan-Jul Aug-Dec } & $\overline{\text { Year }}$ & \multicolumn{3}{|c|}{ Jan-Feb Mar-Jun Jul-Dec } & Year & \multirow[t]{2}{*}{$\mathrm{Q} 1$} & \multirow[t]{2}{*}{$\overline{\mathrm{Q} 2}$} \\
\hline $\begin{array}{l}\text { Dollar deposits } \\
\text { (in USS millionn }\end{array}$ & & & & & 570 & 437 & 848 & & \\
\hline $\begin{array}{l}\text { (in USS million) } \\
\text { Public banks }\end{array}$ & $\begin{array}{l}-5,846 \\
-1,317\end{array}$ & $\begin{array}{r}-303 \\
-102\end{array}$ & $\begin{array}{r}-6,149 \\
-1,418\end{array}$ & $\begin{array}{r}-151 \\
-42\end{array}$ & $\begin{array}{l}570 \\
189\end{array}$ & $\begin{array}{r}430 \\
66\end{array}$ & $\begin{array}{l}848 \\
213\end{array}$ & 198 & 9 \\
\hline Private local banks & $-1,501$ & -350 & $-1,851$ & -13 & 46 & 37 & 70 & 122 & 11 \\
\hline Foreign banks & $-3,029$ & 149 & $-2,880$ & -96 & 335 & 326 & 565 & 37 & 87 \\
\hline Subsidiaries & $-1,573$ & -90 & $-1,664$ & -10 & 120 & 152 & 262 & 36 & 72 \\
\hline Branches & $-1,455$ & 239 & $-1,216$ & -86 & 215 & 175 & 303 & 1 & 15 \\
\hline Residents & $-2,338$ & -358 & $-2,696$ & -115 & 463 & 288 & 636 & 277 & 164 \\
\hline Nonresidents & $-3,509$ & 56 & $-3,453$ & -36 & 106 & 141 & 212 & 79 & -57 \\
\hline \multicolumn{10}{|l|}{ Peso deposits } \\
\hline (in Urs million) & $-3,560$ & 1,552 & $-2,009$ & 1,675 & 1,819 & 249 & 3,743 & 963 & 991 \\
\hline Demand & -724 & 368 & -356 & 929 & -340 & 2,226 & 2,815 & 648 & 696 \\
\hline Time and savings & $-3,375$ & 152 & $-3,224$ & 635 & 1,153 & 501 & 2,290 & 304 & 309 \\
\hline Others & 539 & 1,032 & 1,571 & 110 & 1,006 & $-2,478$ & $-1,362$ & 11 & -14 \\
\hline
\end{tabular}

\section{Progress on bank restructuring has been mixed.}

- BROU. The bank's restructuring is advancing. Profits are exceeding the business plan, and operational costs are lower than programmed. The fiduciary trust to work out BROU's nonperforming loans (NPLs) began operations in April, and the end-March and end-June PCs on the transfer of NPLs to the trust were observed. ${ }^{5}$ While the end-March PC on the contracting of specialized asset recovery services was not observed, this action was taken in April.

- $\quad$ Reprogrammed deposits. In mid-April, BROU began the early release of the second tranche of reprogrammed deposits of about US\$700 million. ${ }^{6}$ The release went smoothly_-some 95 percent of freed funds remained with BROU, with 75 percent in time deposits. Interest rates on remaining reprogrammed deposits were reduced from 6 percent to $3 \frac{1}{2}$ percent, which - while somewhat higher than market average - is consistent with a viable medium-term outlook for the bank.

4 These measures include a law to clarify the definition of the inflation-indexed unit (UI); regular issuance of UI-denominated Treasury and BCU bills (with maturities of 3-5 years); and the imposition of higher reserve requirements on dollar deposits than on peso deposits (lowering the relative cost of peso-denominated accounts).

${ }^{5}$ At end-June, NPLs with a book value of US\$25 million were removed from BROU's books and transferred to the trust. These NPLs included some 45 credits above US $\$ 100,000$ with a book value of US\$1 million that were inadvertently not transferred at end-December.

${ }^{6}$ Deposits were released gradually through July. Depositors had 10 days to move the unfrozen funds out of a 90-day time deposit. 
- Liquidation funds of Banco Montevideo, Banco Comercial, and Banco Caja Obrera. Little progress had been made in disposing the remaining assets in these banks' liquidation funds until mid-year. The end-March PC to select a winning bid for outsourcing asset disposal of these banks was not met. This measure was first envisaged for completion in July 2003 and subsequently rescheduled on several occasions. In June, the authorities began undertaking a series of steps to rejuvenate the process (see Attachment I, paragraph 8).

- Banco de Crédito (BDC). In June and again in July, the BCU attempted to auction assets of the BDC's liquidation fund to generate resources to extinguish remaining depositor claims, but no offers met the authorities' expectations. The authorities revised their strategy and, in mid-August, covered these claims with government bonds (face value) that the liquidation fund received in exchange for assets of the fund. $^{7}$ These assets and those remaining in the liquidation fund will be disposed of by end-December 2004. Performing loans will be securitized, while the management of NPLs will be outsourced.

- $\quad$ Nuevo Banco Comercial (NBC). In May, the BCU approved NBC's final 2003 accounts, which showed a profit of US $\$ 8$ million, driven by NPL recoveries. The IFC has recently indicated that its interest in acquiring a minority equity stake in the bank remains under review, and the authorities intend to continue discussions with the IFC on this matter.

- $\quad$ State mortgage company (BHU). World Bank staff reports good progress in restructuring the bank. Operating costs have been reduced considerably, an improved loan-servicing framework has been adopted, and stronger recovery modalities for NPLs are being put in place. The BHU is withdrawing from construction and commercial real estate lending and is focusing on limited residential lending. A new information system is being introduced, paving the way for disbursement of the second tranche (US\$50 million) under the SAL-I operation.

- Bank supervision. While the BCU has continued to improve its regulatory framework, the hiring of additional staff to strengthen the supervisory capacity of the Bank Superintendency (SIIF) has been slow, holding up a disbursement under the IDB's Financial Sector Loan (which is now expected in the fourth quarter).

8. Progress in other areas of structural reform has been largely disappointing. The tax reform proposal submitted to Congress last year has not moved forward, and is unlikely to do so ahead of the elections. Structural benchmarks for congressional approval of reforms to

\footnotetext{
7 These bonds have been held in the government's portfolio; thus, the operation does not involve an increase in public debt, although the amount of bonds involved (US\$50 million) exceeds the US\$40 million envisaged in the government's earlier strategy to cover these claims (as reported in Country Report No. 03/247, Supplement 2). The government would face marginally higher net interest costs as a result of this operation.
} 
the special pension regimes for the police and the military have not been met. Congressional approval of regulatory frameworks for the water and gas sectors, which are conditionality under the World Bank's SAL-II operation, is also pending. However, the authorities successfully auctioned in May a set of cellular phone licenses (for US\$30 million). In July, the free trade agreement with Mexico came into effect.

\section{Policy Issues}

9. Discussions focused on actions needed to sustain the recovery and stabilization gains achieved under the program, to provide a solid framework for the new government that will take office in March 2005. Despite the better-than-anticipated economic performance, fragilities persist in a number of areas. Accordingly, the discussions centered on the need to maintain prudent fiscal and monetary policies and advance key structural reforms, particularly in the banking sector.

10. The macroeconomic framework for $\mathbf{2 0 0 4}$ has been revised to incorporate the stronger-than-anticipated recovery of growth. Real GDP is now projected to grow at 7 percent (up from 5 percent in the program) to take account of the expansion through the first quarter of 2004. Inflation is projected to remain at the high end of the authorities' 7-9 percent target range for end-2004, and the external current account to post a small surplus, with high growth in both exports and imports. While there are upside risks to this outlook (leading indicators point to growth higher than 7 percent), there are also a number of downside risks, including world oil prices; uncertainties related to the upcoming elections; and possible electricity shortages due to a rainfall deficit and reduced electricity exports by Argentina.

\section{A. Fiscal Policy and Debt Management}

11. To enhance prospects for debt sustainability, the authorities have committed to a higher primary surplus target for 2004. The authorities are now targeting a primary surplus of 3.4 percent of GDP, which implies an improvement of about $3 / 4$-percentage point of GDP over last year. Staff welcomed the strengthening of the target, although it noted that the much better-than-expected revenue performance provided a good opportunity to bolster the fiscal position even further, given the still-fragile medium-term debt outlook. In this vein, staff recommended against the recent elimination of the emergency surcharges and taxes. The authorities explained that the tax cut was consistent with the higher 2004 primary surplus target, despite the negative fiscal implications of the sharp rise in world oil prices and power generation costs (Box 2). To ensure that the primary surplus target for this year will be met, the authorities committed to keeping primary expenditures strictly within the limits of the program (the July wage increase of $5 \frac{1}{2}$ percent was broadly in line with the program) and to continue adjusting public tariffs in a timely manner in line with cost developments. 


\title{
Box 2: Fiscal Implications of the Regional Energy Shortage and Higher World Oil Prices
}

\author{
Regional energy shortage
}

- Uruguay's power generation capacity is mostly based on hydroelectric energy that comfortably exceeds demand under normal weather conditions. To accommodate drought risks, the state-owned power company, UTE, maintains an "insurance" contract for back-up power from Argentina.

- Low rainfall in the first part of the year and energy shortages in Argentina resulted in shortfalls in backup energy supplies, forcing UTE to rely on old thermal-power generators and imported power from Brazil, both considerably more costly.

- To accommodate these higher costs, which have eased somewhat in light of recent rains, the authorities have postponed part of UTE's investment program (by some 0.2 percent of GDP) and raised tariffs by 6 percent (on average) in June (the programmed 4.5-percent increase plus a 1.5-percent premium for unforeseen additional costs), with higher increases for large consumers and lower increases for residential consumers and smaller businesses.

\section{Higher oil prices}

- Uruguay imports, on average, 1.5 million barrels of crude oil per month. For each one-dollar increase in the price of crude oil, costs of the state oil company, ANCAP, are estimated to rise by US $\$ 18$ million ( 0.15 percent of GDP) on an annual basis.

- The government has some discretion in adjusting fuel prices. By law, ANCAP cannot change prices on its own accord; rather, it must submit proposed changes to the Office of Planning and Budget for approval. In the absence of exceptional circumstances, price changes can only be done at the time of public wage adjustments. Petroleum products are subject to specific taxes, which currently yield 1.4 percent of GDP.

- In 2004, the authorities have raised fuel prices by a cumulative 20 percent to mitigate the financial impact of higher crude oil prices on the fiscal program. Fuel prices at the pump are now among the highest in the region. Nevertheless, due to lags in adjusting prices, ANCAP's operating balance is expected to be lower by 0.3 percent of GDP.

\section{To ensure sustainable debt dynamics, the primary surplus should be at least} $31 / 2$ percent of GDP in 2005 and rise to no less than 4 percent of GDP in the medium term. Staff cautioned that any further tax reduction measures should only be taken in the context of a comprehensive tax reform and consistent with the envisaged medium-term fiscal path. The authorities confirmed that there would be no further tax reductions during their time in office, and stressed that, while near-term prospects for tax reform are poor, they remain committed to foster dialogue and seek consensus toward its adoption.

\section{The elimination of the $\mathbf{2 0 0 2}$ emergency surcharges and taxes presents downside} risks for the fiscal program, mainly for 2005. For 2004, on current trends, the revised primary surplus target may well be exceeded, as the full impact of the tax cuts will only be felt next year. Projections for 2005 indicate that the loss of revenue from the eliminated surcharges and taxes would be partly offset by the absence of one-off expenditures in 2004 and higher corporate income tax receipts (because of the strong recovery in 2004); ${ }^{8}$ as a

${ }^{8}$ The one-off expenditures in 2004 are related mostly to the national elections, the clearance of certain arrears accumulated in 2003, and the regularization of the social security bank's debt with the private pension funds. 
result, the 2005 primary surplus target would be achieved based on the authorities' 2005 budget plan that calls for a real increase in spending of 1.5 percent.

14. Improving tax administration and strengthening the institutional framework for the budget will be key to meeting the medium-term fiscal objectives without having to increase already high tax rates.

- While the authorities are continuing to modernize tax administration, staff expressed disappointment with the delays in the reform agenda. The Tax Administration Department's (DGI) modernization plan (supported by a grant from the EU) is behind schedule, due to administrative and legal delays. The creation of an internal audit unit - to improve internal governance and curb evasion, mainly through increased field audits in high-risk sectors - has also been delayed, implying that the establishment of a Large Taxpayers Unit (a structural benchmark for end-September) is now proposed for end-December 2004 (structural benchmark).

- $\quad$ Staff recommended (in line with the fiscal ROSC) that the central government budget law be enhanced to require that: (i) budget documentation include a statement of fiscal policy objectives and a qualitative assessment of the sustainability of fiscal policy; (ii) annual tax expenditure be specified explicitly in the budget to make transparent the costs of tax exemptions and incentives; and (iii) annual revisions to the budget include updated medium-term macroeconomic and expenditure frameworks and a discussion of fiscal risks. ${ }^{9}$ The authorities argued that their budgetary framework provides an adequate forward-looking perspective of fiscal policy, but agreed that including tax expenditure explicitly in the budget would improve transparency of tax policy, and that they would explore the necessary legal channels to require that such spending be included in the budget.

15. Uruguay's debt management strategy focuses on extending the maturity of domestic debt placements, securing timely disbursements from IFIs, and taking advantage of opportunities to issue longer-term debt in the international markets. In addition to the reopening of their global 3-year bond, the authorities have extended the original maturity of dollar-denominated T-bills to 18 months and started issuing inflationindexed T-notes with a maturity of 3 years. The recent US $\$ 250$ million bond issue will cover short-term debt rollover needs through March 2005. The authorities have also stepped up

\footnotetext{
${ }^{9}$ Under the budget law, an incoming administration presents a five-year budget plan to Congress. A statement annexed to the law identifies current expenditure for the first year of the 5-year period and annual investment expenditure for all five years. Annual and withinyear adjustments may be made to current expenditure for expected inflation. Prior to the start of the second and subsequent budget years, a budget reporting law and a budget execution statement are submitted to Congress, at which time changes to the five-year central government budget law may be presented.
} 
efforts to implement policies linked to the pending tranches under World Bank's SAL I facility and the IDB's Financial Sector Loan, which they now expect to be disbursed in the second half of the year. Staff welcomed these steps and urged the authorities to take advantage of opportunities to extend the maturity of the relatively large stock of peso T-bills, and issue longer-term instruments in the international markets if market conditions permit.

\begin{tabular}{|c|c|c|c|c|}
\hline \multicolumn{5}{|c|}{ Uruguay: Scheduled Disbursements from Multilateral Development Banks, 2004-05 } \\
\hline Loan & $\begin{array}{l}\text { Amount } \\
\text { (US\$ million) }\end{array}$ & $\begin{array}{l}\text { Original Timing } \\
\text { (Country Report 04/17 }\end{array}$ & Conditionality & Disbursement status \\
\hline World Bank SAL I & 50 & Q1/2004 & BHU restructuring. & Delayed. Likely in Q4/2004. \\
\hline World Bank SAL I & 50 & Q3/2004 & Unemployment insurance scheme. & Delayed. Likely in Q4/2004. \\
\hline $\begin{array}{l}\text { IDB Financial Sector } \\
\text { Loan }\end{array}$ & 60 & Q1/2004 & Strengthening of financial regulation. & Delayed until Q4/2004. \\
\hline $\begin{array}{l}\text { IDB Multisector } \\
\text { Financing Program }\end{array}$ & 35 & Q3/2004 & $\begin{array}{l}\text { Onlending of medium- and long-term } \\
\text { credit to private enterprises. }\end{array}$ & $\begin{array}{l}\text { Now US } \$ 6 \text { million and } \\
\text { rephased to Q4/2004. }\end{array}$ \\
\hline World Bank SAL II & 75 & $\ldots$ & $\begin{array}{l}\text { Improvements in regulation and } \\
\text { efficiency of public utilities, health, and } \\
\text { education. }\end{array}$ & 2005 \\
\hline World Bank SAL II & 100 & $\cdots$ & $\begin{array}{l}\text { Montevideo port concession; reforms in } \\
\text { health and education sectors. }\end{array}$ & 2005 \\
\hline
\end{tabular}

\section{B. Monetary and Exchange Rate Policies}

16. The authorities intend to continue with the peso float, with base money as the intermediate target of monetary policy. The authorities noted that the tightening of the base money target in early 2004 was in response to concern about signs of a pickup in inflation and the BCU's monthly survey showing inflation expectations above the target range. While the strong economic recovery could lead to higher-than-projected money demand, the authorities thought that this could be offset by rising domestic interest rates and uncertainty during the election period. Staff broadly concurred with this assessment, and it is proposed to revise the base money targets under the program (as shown in Table 3). Staff also supported: (i) the shift toward a target range for

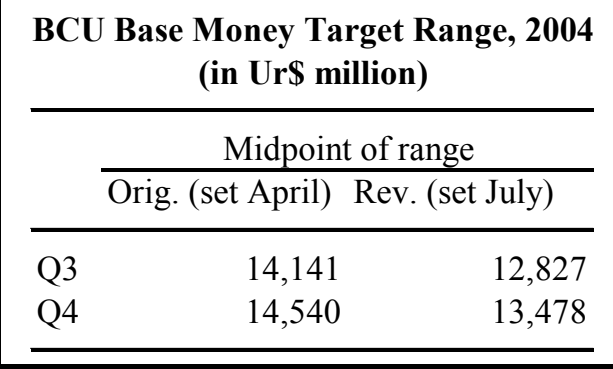
base money, in light of the uncertain impact of the elections on money demand; (ii) the creation of a repo facility to improve the BCU's capacity to manage liquidity; and (iii) the recent lowering of the BCU's inflation target range for June 2005.

\section{The strong external environment has allowed the BCU to raise modestly (by} US\$80 million) its targeted build up of reserves this year. Staff suggested a larger increase in the end-year NIR target that would lock in the overperformance with respect to the 
program target in the first half of the year. ${ }^{10}$ Staff pointed out that a further build up was warranted in light of the relatively low level of coverage of deposits and short-term debt. The authorities agreed that a further NIR increase would be desirable over time but noted the risk of some volatility in money demand and the balance of payments in the run up to the elections, and that a higher target would result in the issuance of additional central bank debt and a widening of the quasi-fiscal deficit. The authorities reiterated their commitment to reduce financial dollarization, noting that the required strengthening of confidence in the peso would take time.

\section{Banking Reforms}

\section{Progress in reforming the banking system has been uneven, with advances in} restructuring the public banks but disappointing results so far in asset disposal and recovery (Box 3). Staff welcomed the continued improvement in financial soundness indicators, the regulatory framework, and the public banks, while regretting the repeated delays with the bank liquidation process and the failure to meet the end-March PC on the outsourcing of asset disposal of the liquidation funds. This lack of progress risks

undermining creditor discipline and increasing the fiscal costs of bank restructuring, and staff expressed concern about governance risks resulting from inadequate financial reporting by the liquidation funds and the poor information flow between the funds and the BCU (preliminary information suggest that the stock of nonreconciled items stand at around US\$20 million). ${ }^{11}$ The authorities recognized the delays and explained that they resulted mainly from the lack of cooperation from unionized labor in the liquidation funds (for fear of job losses) as well as resistance by interest groups to the strategy for asset disposals (sales or outsourcing), which represents a break with the past practice of socializing losses in bank resolutions.

\section{To address governance concerns and bring asset disposal back on track, the} authorities have committed to the following steps as prior actions for this review:

- $\quad$ Appointing a full-time supervisor to oversee the implementation of the asset disposal strategy;

- $\quad$ Completing an inventory of assets, as well as end-May balance sheets for each of the liquidation funds;

- $\quad$ Submitting information on NPLs obtained from the asset inventory to the SIIF for inclusion in the credit registry;

${ }^{10}$ This overperformance was largely due to a lowering of the base data (end-2003) used to set the targets. In view of a prospective large overperformance on NIR for end-2003, the BCU in December reduced its reserve holdings by US\$160 million in a portfolio operation. However, in early 2004 this operation was reversed, improving NIR by the same amount.

${ }^{11}$ Given the uncertainties surrounding the asset recovery process, the program's fiscal projections conservatively assume zero collections for the government. 
- $\quad$ Hiring audit and accounting firms for the preparation of: (i) financial statements for the funds' operations since inception; and (ii) an external audit of these statements;

- $\quad$ Contracting a firm through a competitive bidding process to manage the assets in the liquidation funds of Banco Comercial, Banco Montevideo, and Caja Obrera and transferred to the firm a first tranche of NPLs of at least US\$300 million; and

- $\quad$ Transmitting the liquidation funds' end-July financial statements to the Ministry of Economy and Finance (MEF) and BCU.

\section{Box 3. Bank Liquidation Funds}

During the 2002 banking crisis Uruguay's four largest private domestic banks experienced serious financial difficulties, and they were ultimately liquidated (Country Report No. 03/247, Supplementary Information). Their assets (mainly NPLs after the good assets were shifted to NBC) were transferred to four liquidation funds under the BCU's administration.

Banco Comercial, Montevideo, and Caja Obrera

The liquidation funds for these banks were created in December 2002, but asset disposal, except for those purchased by NBC, has lagged.

Under the original program, the outsourcing of the disposal of at least two asset groups was set as a structural PC for end-July 2003, but this PC was not observed. The authorities then revised their strategy and decided to outsource the management of the entire stock of assets by end-March 2004 (structural PC). Five asset management companies were pre-qualified, but the auction could not be held because the liquidation funds were unable to assemble the required information for due diligence.

To accelerate the asset disposal process, the BCU terminated in May 2004 most of the liquidation funds' employees and hired an external consulting firm to undertake an inventory, document the assets for their auction, and prepare end-May balance sheets. The recently concluded inventory shows that the remaining assets in the funds have a book value of approximately US $\$ 325$ million.

Any recoveries from the remaining assets will be distributed on a pro-rata basis among the claims against the liquidation funds. The government and the BCU own close to two-thirds of these claims. Recently, the liquidation funds made a pro-rata cash distribution to their creditors. Although staff had recommended deferring the distribution until the funds' financial statements were finalized, the authorities explained that the information on the liability side of the funds to determine the distribution was well documented.

\section{Banco de Crédito}

Its liquidation fund was created in February 2003. Disposal of the assets in this fund is more advanced following: (i) agreement in 2003 with creditors to trade their claims against government bonds at face value; (ii) repayment by the former minority shareholder of its large stock of outstanding loans; and (iii) the repayment in August 2004 of remaining claims with government bonds. As described in paragraph 7, the authorities envisage that the remaining assets will be disposed of by end-2004. 


\section{Continued progress in asset disposal and oversight of the liquidation funds is expected as follows:}

- $\quad$ Financial statements from the inception of the liquidation funds will be completed by end-September; and their financial audits by end-October (structural PC).

- All remaining assets in the liquidation funds of Banco Comercial, Banco Montevideo, and Banco Caja Obrera will be transferred to the asset manager by end-October (structural PC).

- $\quad$ The liquidation funds will produce monthly financial statements (by the 20th of the following month) and transmit these to the Ministry of Economy and Finance (MEF) and BCU (monthly structural PC beginning September).

- $\quad$ As of the last quarter of 2004, the liquidation funds will begin publishing quarterly financial reports within 30 days of the close of the quarter (end-January 2005 structural PC).

Staff welcomed the authorities' decision to close out the bank stabilization fund (FSBS), which had been used as envisaged to back sight and savings deposits at qualifying banks, and to apply the unused balance toward an early repurchase to the Fund. Staff expressed concern, however, about a number of congressional initiatives which aim at extending compensation to creditors of the liquidated banks. ${ }^{12}$ The authorities informed staff of their opposition to such compensation plans for depositors and other creditors, although they recently offered bondholders and depositors with claims above US\$100,000 a swap of these claims and various dollar-denominated government bonds maturing over the medium term for new, longer-term, inflation-indexed, peso-denominated government bonds. Staff expressed concern that this could be seen as a bailout of bondholders and large depositors that runs counter to the authorities' earlier limited compensation plan and to good bank resolution practices. Preliminary estimates suggest that the swap would be broadly NPV neutral, while smoothing the maturity profile and improving the currency composition of the public debt; albeit, at a cost of a higher nominal stock of debt. The authorities underscored that this was not a bailout, as the swap was market-based and included no special incentives for participation in the swap.

21. BROU's financial performance has begun to improve and its restructuring is advancing (Box 4). Staff reviewed BROU's performance during the first quarter, which was better than foreseen, and confirmed that BROU would be viable under its business plan.

- $\quad$ Staff verified that progress is being made in setting up an asset management company (AMC) to manage BROU's fiduciary trust with NPLs. Staff stressed that successful

12 In May, Congress narrowly rejected a proposal to provide depositors in an offshore bank owned by Banco Montevideo a claim on the bank's liquidation, and other proposals include using recoveries from the liquidation funds to benefit large depositors and bondholders. 
recovery of NPLs would require substantial delegation of powers to the AMC's staff, reserving direct involvement by the Executive Board only to strategic matters.

- The authorities confirmed their plan to release the final tranche of reprogrammed deposits according to the original schedule (which would begin in July 2005), and committed to consult closely with staff on any changes to this plan.

\section{Box 4. Progress under BROU's Restructuring Plan}

In December 2003, BROU adopted a restructuring plan to address balance sheet weaknesses and ensure the bank's viability through operational restructuring (see Country Report No. 04/172, Appendix II). Progress to date includes:

- Recovery of NPLs. An asset management company (AMC) was established to manage the NPLs removed from BROU's books and transferred to the fiduciary trust. Under its business plan, the AMC would work out large NPLs while the recovery of smaller NPLs would be outsourced. The AMC has retained a consultant to produce recovery manuals and hired collection agents and legal services to help with asset recovery. NPL documentation is being gradually transferred from BROU to the AMC. Cash recoveries from NPLs through June already exceeded the 2004 target. $^{1}$

- Operational restructuring. To reduce operating costs, almost 300 employees (out of 4,000) went into early retirement during the last quarter of 2003 and the first quarter of 2004, and BROU continued to streamline its extensive branch network. In April, interest rates on reprogrammed deposits were reduced from 6 percent to $3 \frac{1}{2}$ percent, closer to market levels.

- Business focus and strengthening risk management. BROU is refocusing lending and deposit activities in the peso market. During the first half of 2004, local-currency lending rose in line with the business plan, while dollar-denominated lending was flat. At the same time, BROU began offering savings instruments in local currency. BROU continues to work on adopting credit-scoring mechanisms, improving credit risk assessment, and implementing credit monitoring procedures.

1/ The targeted recovery schedule for the first tranche of transferred NPLs is as follows: US\$32 million in 2004; US\$148 million in 2005; US\$160 million in 2006; and US\$48 million in 2007 (excluding interest).

\section{The transformation of BHU into a nonbank mortgage lending institution is} beginning, but BHU's financial situation will remain weak for some time. Staff welcomed the implementation of reforms in line with conditionality under the World Bank SAL I and the servicing of BHU's obligations to BROU. However, it noted that BHU will still require support from the government to make this year's amortization payment to BROU, and will remain in a relatively weak financial position for several years to come. The authorities shared this assessment and underscored their commitment to steadfast implementation and close monitoring of the bank's restructuring plan.

\section{The setup phase of NBC has been completed, and the bank's focus must now} shift towards achieving its business plan targets. NBC is highly liquid and well capitalized, but its operating costs are somewhat higher than envisaged. Staff expressed its disappointment over the slow progress in the negotiations with the IFC for its acquisition of an equity stake in the bank, and encouraged the authorities to continue pursuing discussions with them. IFC participation would facilitate a strengthening of NBC's governance, 
including by increasing the size of the bank's Executive Board and ensuring the appointment of Board members with a strong background in commercial banking.

24. The authorities remain committed to continue strengthening bank supervision, but progress has been slow in hiring needed staff. The regulatory environment has been improved, especially regarding credit risk resulting from lending in foreign currency to borrowers with peso incomes. However, staff stressed that for the strengthened regulations to be effective, the SIIF needs sufficient staffing levels and capacity. The authorities agreed and noted the ongoing efforts to improve supervisory capacity, with technical support from the IDB and the Fund, and to hire additional SIIF staff, which has been delayed mainly by BCU statutory hiring procedures.

25. The authorities are considering the introduction of a limited deposit insurance scheme, which would need to be implemented in a cautious manner given the current structure of the banking system. The plan, being formulated with the assistance of Canadian experts, would include differential charges and/or coverage for peso and dollar deposits. The authorities agreed with staff that the design and implementation of such a scheme would have to be carefully prepared in light of Uruguay's current circumstances and the dominating role played by a large public bank with an explicit government guarantee of deposits (i.e., BROU).

\section{Vulnerabilities AND Program Risks}

26. While program risks have further diminished since the last review, important vulnerabilities remain, and maintaining sound policies is essential to contain these risks. Most indicators of financial vulnerability have continued to improve, including the stock of deposits, gross reserve coverage, and capitalization and loan quality of the banking system, suggesting increased resilience to external or domestic shocks. Nevertheless, the public debt is still high (110 percent of GDP as of end-March) and mostly dollar-denominated, with a significant short-term component; and the recent tax cuts leave little room for any deviation from continued tight control over expenditure if the 2005 primary surplus target is to be met. Financial dollarization remains entrenched; and weaknesses remain in the banking system. In particular, the majority of dollar-denominated deposits are sight deposits and the public banks (which hold half of total deposits) are still in the process of restructuring. Delays in the resolution of the liquidated banks raise governance concerns in the restructuring process that could adversely affect prospects for the establishment of a sound banking system, and additional costs of bank restructuring might be beginning to surface, while there are already large fiscal contingent liabilities associated with the banking system. In addition, the upcoming election period could see heightened market volatility; weakened fiscal discipline; and slower progress in restructuring the banking system.

27. Uruguay is exposed to interest rate and oil price risks. Roughly one-half of the public debt is at variable rates, but this risk is mitigated somewhat as the largest part of this debt is to IFIs (as a result, interest rates are diversified and increases in sovereign spreads would not affect debt service costs). Staff estimates that the full-year effect of a onepercentage point increase in U.S. interest rates on Uruguay's interest bill amounts to 0.3 percent of GDP. An additional source of interest rate vulnerability stems from the 
0.5 percent of GDP (assuming no volume change) and, if fully passed through, an estimated first-round impact on inflation of $1 \frac{1}{4}$ percentage points.

\section{Baseline medium-term debt dynamics are sustainable but remain vulnerable to}

shocks. The updated debt sustainability analysis shows that under the baseline scenario, the debt-to-GDP ratio will decline gradually, but still remain above 65 percent through 2012 (Box 5). Sustainability concerns could therefore arise in case of a longer-term economic slowdown or a deterioration in the government accounts.

29. Fund exposure to Uruguay is likely to remain high for some time. Despite the authorities' welcome decision to forego one disbursement under the current program, credit outstanding to the Fund would reach 656 percent of quota (over 20 percent of GDP) at the end of the arrangement in March 2005. The repayment burden to the Fund will rise steeply in 2006 and 2007 when payment obligations are projected at about 71/4 and 51/2 percent of GDP, respectively. Several of the presidential candidates have already announced that if elected they would seek a new Fund-supported program.

\section{Box 5. Public Debt Sustainability Analysis}

In updating the baseline DSA analysis presented in Country Report No. 04/172 (Appendix III), staff considered it appropriate to continue to assume an average medium-term primary surplus of $3 \frac{1}{2}$ percent of GDP, real GDP growth of 3 percent, and a modest real appreciation of the exchange rate. Under these assumptions, public debt would decline over the medium term from 97 percent of GDP in 2003 to around 65 percent by 2012 (assuming all contingent liabilities owing to bank restructuring come due; if there are no additional bank restructuring costs, it would decline to around 60 percent). Financing gaps, which begin emerging in 2005, will require additional market and IFI financing.

Uruguay's high public debt continues to be a major vulnerability. Large shocks to key variables in the standard DSA analysis such as real growth, real interest rates, and the real exchange rate (depreciation) would lead to increases in the public debt-to-GDP ratio that are either unsustainable or would raise serious doubts as to debt sustainability. However, it must be recognized that Uruguay recently experienced important shocks and has adjusted policies in response so that these shocks are unlikely to unfold.

Staff has analyzed three alternative shocks to key macroeconomic variables: (i) an average decline of real GDP growth by 1 percent; (ii) a 200-basis point increase in interest rates over the medium term; and (iii) weak confidence in the peso that prevents the expected appreciation in the real exchange rate. Even in these cases, the public debt ratio is generally not resilient. Lack of appreciation of the real exchange rate would leave the public debt at dangerously high levels. Slower growth, combined with a policy response that aims at offsetting the slow-down by lowering the primary surplus targets, would lead to a rising debt ratio. Moreover, even if additional fiscal efforts were undertaken to meet the primary balance path under the baseline, the debt ratio would only decline to around 75 percent by 2012 . Finally,

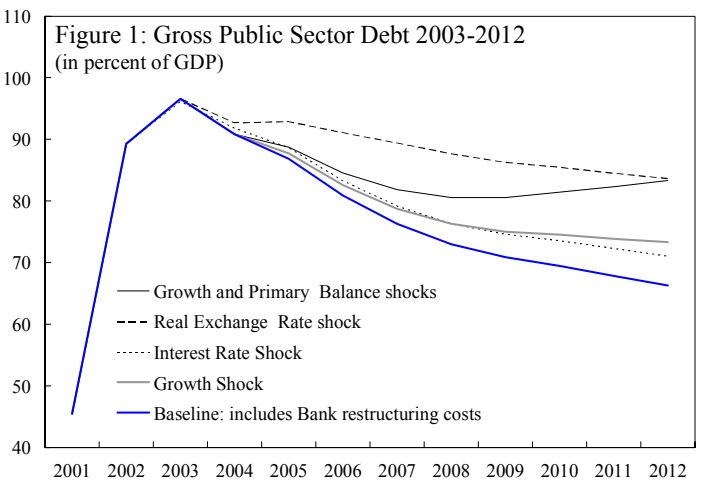
higher interest rates over the medium term, under the baseline primary surplus path, would leave the debt ratio above 70 percent by 2012 (Figure 1). 


\section{Program Financing, Monitoring, and Safeguards}

30. Financing Assurances. Financing needs through March 2005 have been secured, and prospects for next year are closely linked to domestic financial conditions. The medium-term outlook is dependent on the extent of market access and financial assistance from the IFIs. Staff's baseline scenario for 2005 assumes modest access to domestic and international financial markets, which depends, of course, on maintaining sound policies.

31. Program Monitoring. While Uruguay's statistical database has been generally adequate for assessing and monitoring macroeconomic policies, there have been long data lags in the fiscal area. To remedy the problem, the authorities have created a coordinating committee consisting of representatives from the MEF, BCU, BROU, and BHU to ensure timely provision of fiscal data in line with the commitments set out in the TMU (a prior action for this review). Prior actions, performance criteria, benchmarks, and indicative targets under the program are specified in the attached MEFP and TMU (Attachments I and II). The sixth review is expected to take place in November 2004.

32. Safeguards. The recommendations of the 2002 Safeguards Assessment are being implemented, albeit with delay. The external audit of the BCU's 2003 financial statements was finalized in March, and a supplemental audit of the FSBS, focusing on the resource use by recipient banks, is ongoing. In addition, the BCU has created an independent audit committee to oversee the bank's financial reporting practices.

\section{STAFF APPRAISAL}

33. Uruguay is emerging from a long period of economic recession at a faster-thanexpected pace. The improved situation is a product of the sound macroeconomic policies pursued by the authorities and the supportive external environment. Staff encourages the authorities to further capitalize on the current favorable environment, continue with sound macroeconomic policies, and push ahead with structural reforms to set the basis for a sustained expansion of the economy.

34. Uruguay's fiscal accounts have continued to improve, and achieving the revised higher primary-surplus target under the program will buttress the medium-term outlook for fiscal consolidation. Staff welcomes the strengthened primary-surplus target for 2004, although it considers that the stronger growth dividend for revenue would have been a good opportunity to reinforce the fiscal position even further, given the still-fragile mediumterm debt outlook. Staff commends the authorities' commitment to maintain expenditure restraint, keep public utility tariffs broadly aligned with operating costs, and refrain from any further tax reductions. Delivering on these commitments will be essential to maintain market confidence and meet the medium-term fiscal consolidation goals, as there is little scope for fiscal slippage.

35. Staff regrets the slow progress on fiscal reforms. Meeting the medium-term fiscal objectives will depend crucially on addressing structural fragilities of Uruguay's public finances by strengthening revenue administration, reforming the tax system and the specialized pension funds of the police and military, and improving the institutional 
35. Staff regrets the slow progress on fiscal reforms. Meeting the medium-term fiscal objectives will depend crucially on addressing structural fragilities of Uruguay's public finances by strengthening revenue administration, reforming the tax system and the specialized pension funds of the police and military, and improving the institutional budgetary framework. Staff encourages the authorities and other concerned parties to continue working toward a consensus on these reforms.

36. Monetary policy is being conducted in a prudent manner. Staff supports the tightening of monetary targets in 2004 designed to stem any sustained deviation of inflation from the BCU's target range. Actions taken to improve the conduct of monetary policy, such as the introduction of a repo facility, are also welcome. While the authorities have raised the 2004 NIR target under the program, staff encourages them to use the opportunity of a stronger-than-programmed balance of payments to bolster Uruguay's NIR position even further, in anticipation of the large medium-term debt service obligations.

37. Maintaining momentum for restructuring the public banks is essential to ensure their viability, improve creditor discipline, and minimize potential fiscal costs. Staff welcomes progress made in the restructuring of BROU and BHU. For a successful workout of BROU's nonperforming loans, the asset management company (AMC) will need sufficient independence and delegation of powers to its staff. In addition, the AMC should report on a quarterly basis on its activity and performance. The unfreezing of the second tranche of reprogrammed deposits went smoothly, and staff supports the authorities' intention to maintain the schedule for the release of the third and final tranche (scheduled for mid-2005). Strict adherence to the BHU reform program is essential to ensure that the bank can service its obligations without recourse to budget support.

38. The lack of progress in the bank liquidation funds has cast doubt on the bank restructuring process and should be addressed without delay. Staff is very concerned about the absence of appropriate financial record-keeping at the funds, which in turn raises questions on governance in the liquidation process. Dealing with the remaining assets in the liquidation funds in a transparent way is important to raise creditor discipline, limit fiscal costs, and normalize credit conditions. The actions taken by the authorities prior to the Board's consideration of this review provide an important step toward rectifying the situation, by initiating the asset disposal process and bolstering financial disclosure. However, the authorities must follow these actions with timely implementation of the remaining steps under the program, which will be closely monitored in the remaining reviews. Moreover, staff is concerned over the potential rise in nominal debt from the recent swap offer given to bondholders and large depositors of these banks, and the authorities should refrain from granting any further relief.

39. Appropriate resources need to be devoted to ensure the timely provision of fiscal data. The decision to create a formal monitoring committee, with participation of the MEF, $\mathrm{BCU}, \mathrm{BROU}$, and BHU, is a welcome step to help ensure timely reporting of fiscal performance under the program. 
40. While the risks to the program have diminished, significant vulnerabilities remain and leave no room for policy slippages. The authorities' decision to forego one disbursement under the arrangement reflects a strengthening of Uruguay's external position. Nonetheless, important risks remain from the high degree of financial dollarization, the large public debt, and remaining weaknesses in the banking system. To manage these risks, it will be crucial to protect the main elements of the program, particularly during the upcoming election period.

41. Notwithstanding these risks, staff supports the authorities' request for waivers and completion of the fifth review. Performance under the program has been broadly satisfactory, remedial measures have been taken to address the missed structural performance criteria, and the authorities are strongly committed to sound macroeconomic policies and the necessary reform of the banking sector. 
Figure 1. Uruguay: Activity and Prices
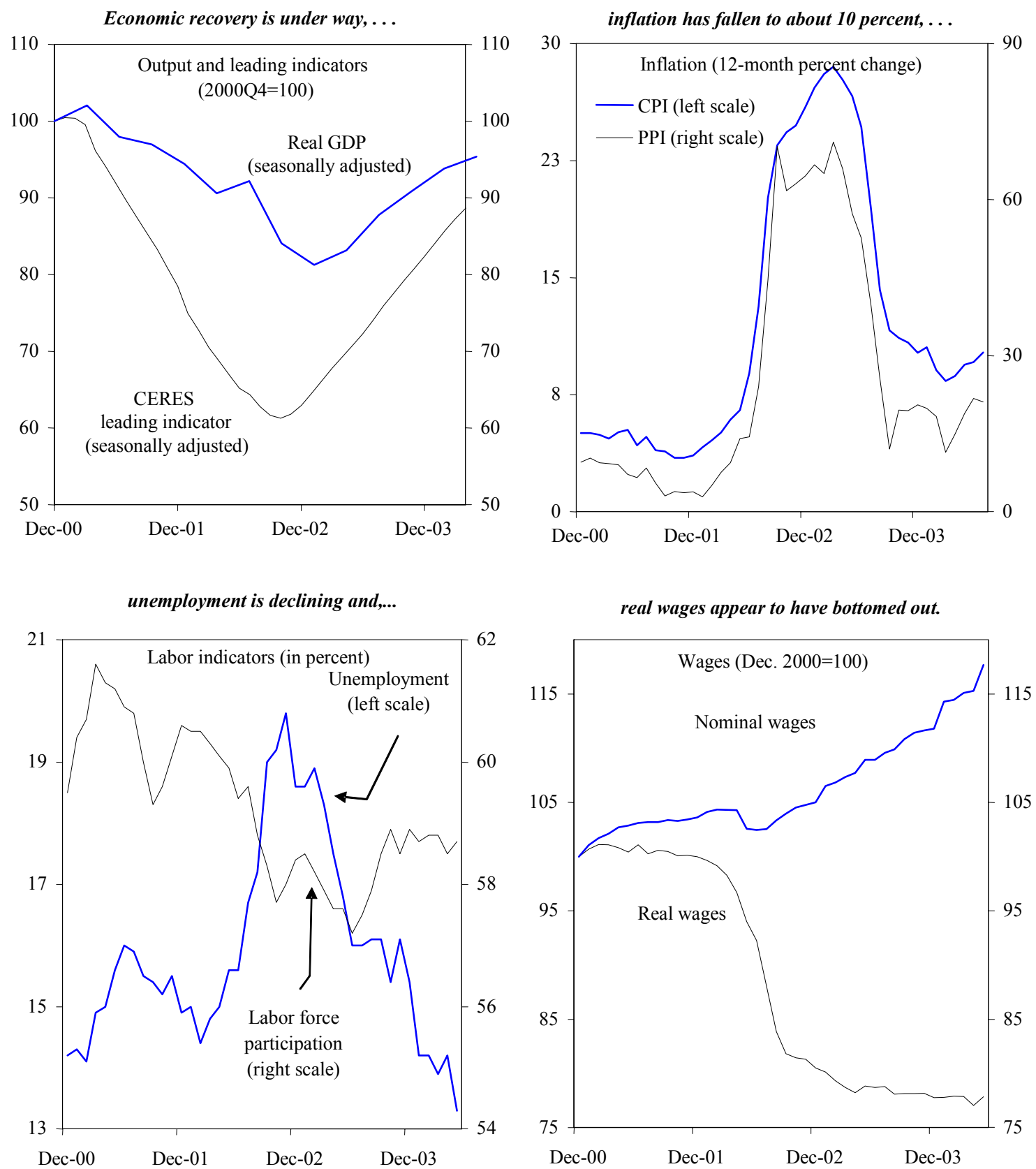

Source: Central Bank of Uruguay; Ministry of Economy and Finance; CERES; and Fund staff estimates. 
Figure 2. Uruguay: External Sector Indicators
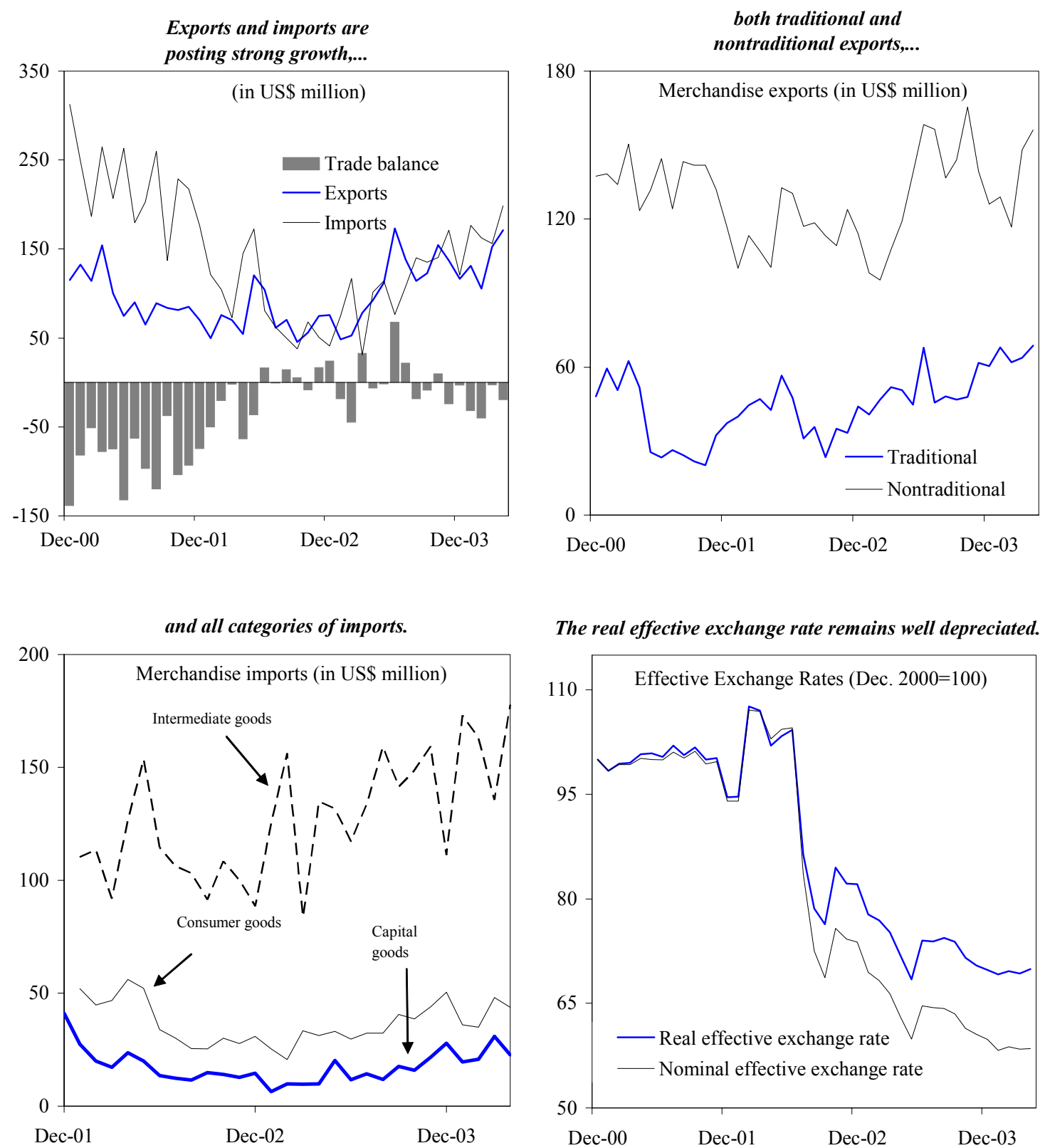

The real effective exchange rate remains well depreciated.

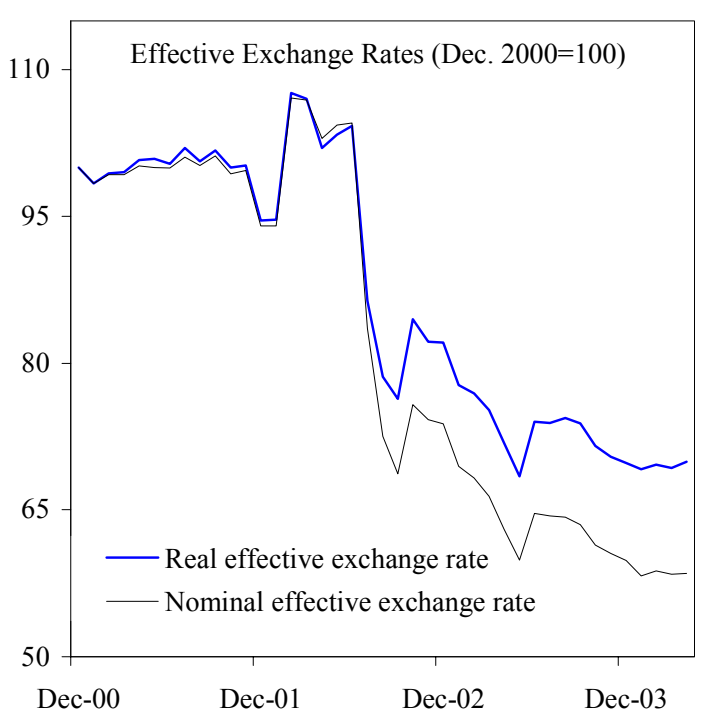

Source: Central Bank of Uruguay; Ministry of Economy and Finance; CERES; and Fund staff estimates. 
Figure 3. Uruguay: Financial and Vulnerability Indicators
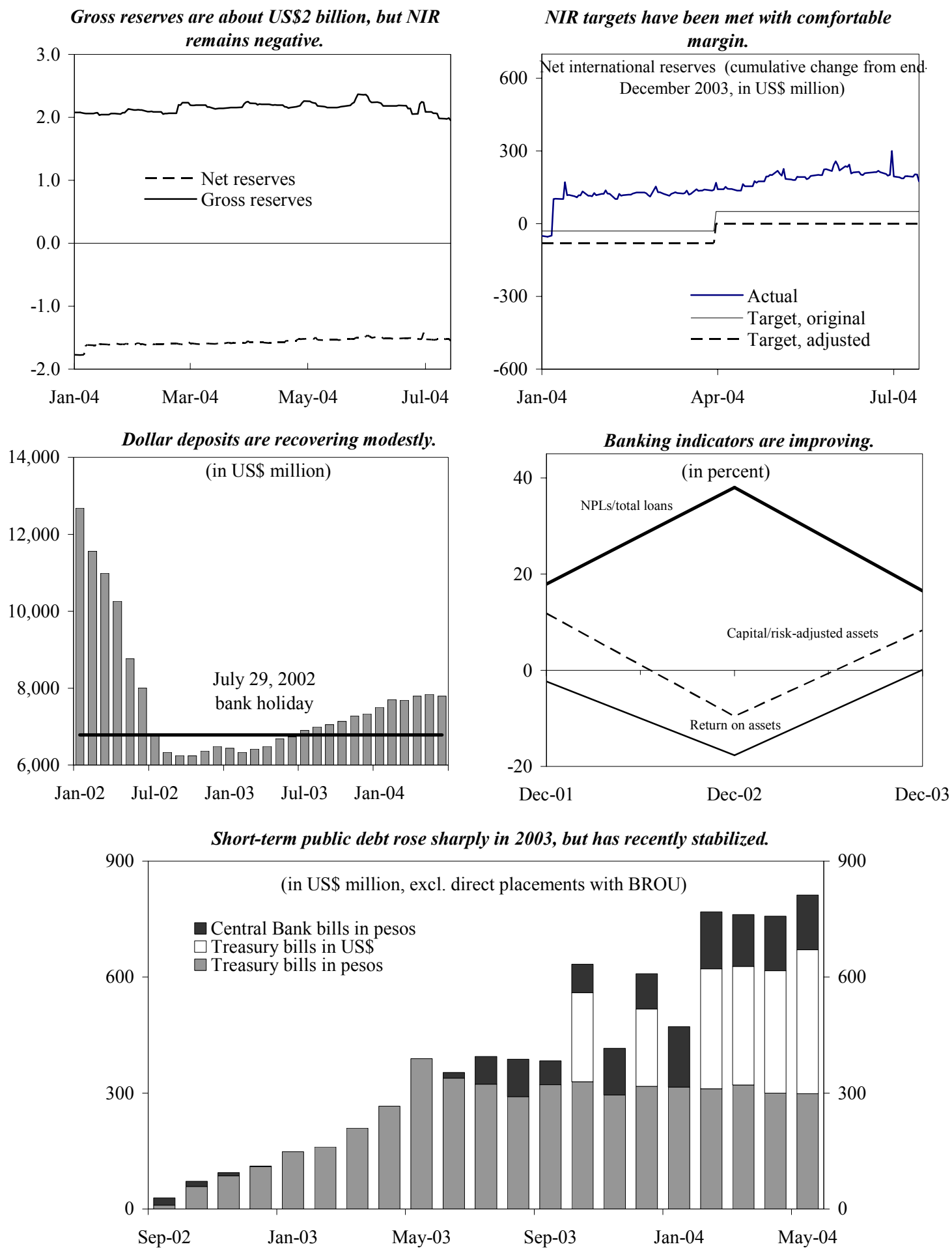

Source: Central Bank of Uruguay; Ministry of Economy and Finance; and Fund Staff estimates. 
Figure 4. Uruguay: Fiscal and Monetary Indicators
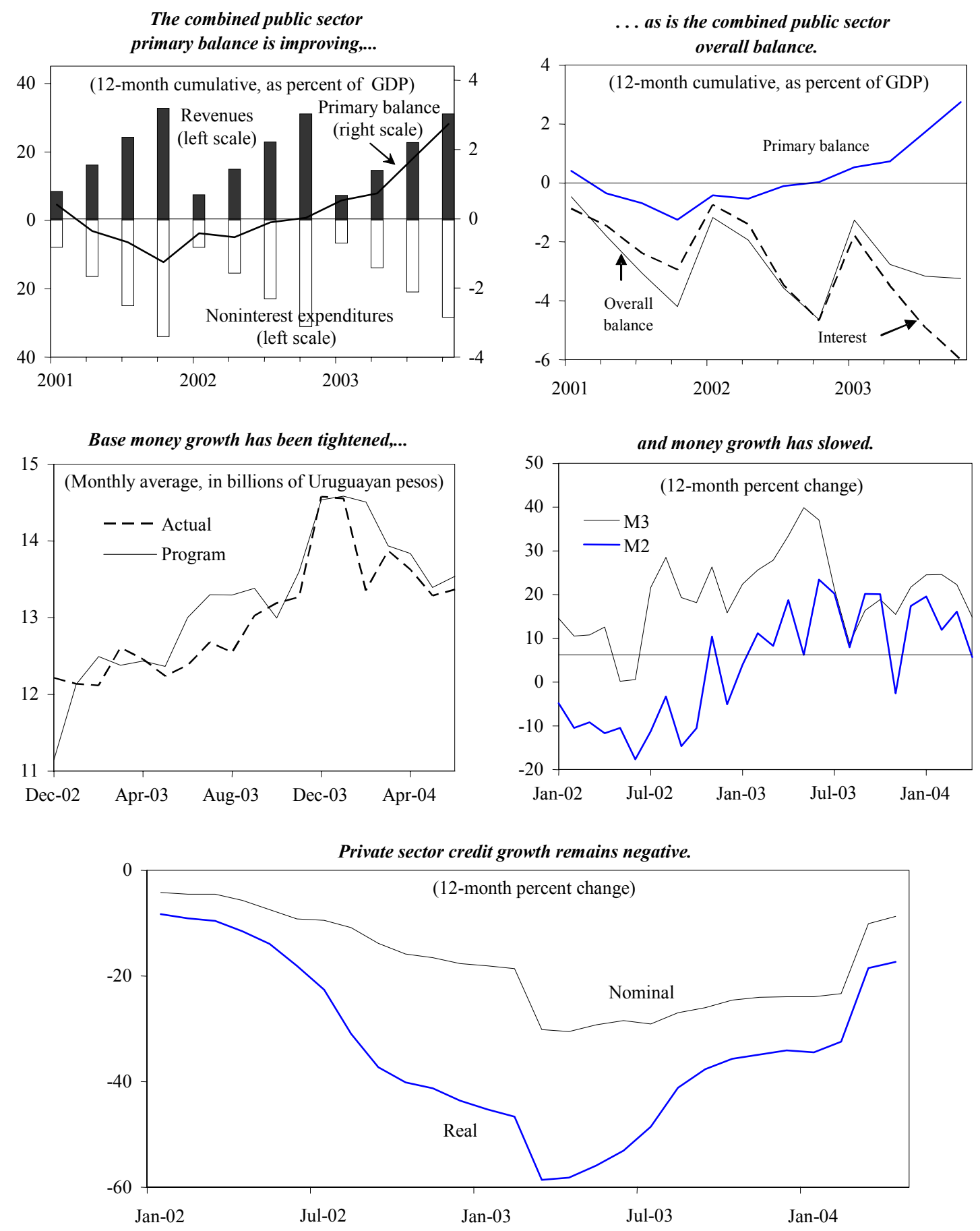

Source: Central Bank of Uruguay; Ministry of Economy and Finance; and Fund Staff estimates. 
Table 1. Uruguay: Selected Economic and Financial Indicators

\begin{tabular}{|c|c|c|c|c|c|c|}
\hline & \multirow[b]{2}{*}{2000} & \multirow[b]{2}{*}{2001} & \multirow[b]{2}{*}{2002} & \multirow[b]{2}{*}{2003} & \multicolumn{2}{|c|}{2004} \\
\hline & & & & & Report 04/172 & Rev. Proj. \\
\hline & \multicolumn{6}{|c|}{ (Percent change) } \\
\hline \multicolumn{7}{|l|}{ Output, prices, and wages } \\
\hline Real GDP & -1.4 & -3.4 & -11.0 & 2.5 & 5.0 & 7.0 \\
\hline \multicolumn{7}{|l|}{ Contributions to growth (percent) } \\
\hline Consumption & -1.3 & -2.2 & -15.2 & -1.0 & 4.0 & 7.4 \\
\hline Investment & -2.2 & -1.4 & -5.0 & 2.7 & 1.4 & 0.8 \\
\hline Net exports & 2.2 & 0.3 & 9.1 & 0.9 & -0.5 & -1.2 \\
\hline GDP deflator & 4.0 & 5.3 & 18.7 & 17.9 & 8.2 & 9.2 \\
\hline \multicolumn{7}{|l|}{ CPI inflation } \\
\hline Average & 4.8 & 4.4 & 14.0 & 19.4 & 7.9 & 9.3 \\
\hline End of period & 5.1 & 3.6 & 25.9 & 10.2 & 7.7 & 9.0 \\
\hline \multicolumn{7}{|l|}{ Exchange rate change (Ur\$/US\$) } \\
\hline Average & 6.7 & 10.1 & 62.1 & 30.4 & $\ldots$ & $\ldots$ \\
\hline End of period & 7.7 & 18.0 & 84.2 & 7.3 & $\ldots$ & $\ldots$ \\
\hline Average public sector wage (end of period) & 2.9 & 5.1 & 0.5 & 7.9 & $\ldots$ & 9.7 \\
\hline \multicolumn{7}{|l|}{ GDP } \\
\hline In Ur\$ billions & 243.0 & 247.2 & 261.0 & 315.4 & 363.0 & 368.7 \\
\hline In US\$ billions & 20.1 & 18.6 & 12.1 & 11.2 & 12.1 & 12.2 \\
\hline \multicolumn{7}{|l|}{ Monetary indicators $1 /$} \\
\hline BCU monetary liabilities & -0.1 & 4.1 & -7.4 & 25.3 & $\ldots$ & 11.4 \\
\hline Currency issued & -3.9 & -0.2 & 5.8 & 22.4 & 15.5 & 12.6 \\
\hline M-2 & 3.5 & 0.6 & -5.1 & 17.4 & 14.4 & 16.8 \\
\hline M-3 & 10.2 & 19.6 & 15.8 & 21.7 & 14.5 & 19.8 \\
\hline \multirow[t]{2}{*}{ Credit to the private sector (constant exch. rate) 2/ } & 0.3 & -3.8 & -17.6 & -23.9 & 1.6 & 2.0 \\
\hline & \multicolumn{6}{|c|}{ (Percent of GDP, unless otherwise indicated) } \\
\hline \multicolumn{7}{|l|}{ Public sector operations } \\
\hline Revenue & 31.2 & 32.4 & 31.1 & 31.1 & 30.6 & 30.5 \\
\hline Noninterest expenditure (incl. discrepancy) & 32.7 & 33.6 & 31.1 & 28.4 & 27.4 & 27.1 \\
\hline Primary balance & -1.5 & -1.2 & 0.0 & 2.7 & 3.2 & 3.4 \\
\hline Interest & 2.6 & 2.9 & 4.7 & 6.0 & 6.5 & 6.5 \\
\hline Overall balance & -4.1 & -4.1 & -4.6 & -3.2 & -3.3 & -3.1 \\
\hline \multicolumn{7}{|l|}{ Savings and investment } \\
\hline Gross domestic investment & 14.0 & 13.8 & 11.5 & 13.1 & 11.1 & 12.5 \\
\hline Gross national savings & 11.1 & 10.9 & 13.1 & 13.7 & 11.7 & 12.8 \\
\hline Foreign savings & 2.8 & 2.8 & -1.6 & -0.7 & -0.7 & -0.3 \\
\hline \multicolumn{7}{|l|}{ External indicators } \\
\hline Merchandise exports, fob (US\$ millions) & 2,384 & 2,144 & 1,934 & 2,273 & 2,455 & 2,808 \\
\hline Merchandise imports, fob (US\$ millions) & 3,311 & 2,914 & 1,872 & 2,092 & 2,292 & 2,639 \\
\hline Merchandise terms of trade (percentage change) & -6.6 & -0.7 & 4.8 & 3.3 & 2.0 & 0.3 \\
\hline Current account balance & -2.8 & -2.8 & 1.6 & 0.7 & 0.7 & 0.3 \\
\hline Overall balance of payments (US\$ millions) 3/ & 167 & 302 & $-2,323$ & 1,311 & 700 & 663 \\
\hline Public debt 4/ & 45.5 & 53.8 & 93.8 & 108.2 & 104.6 & 102.7 \\
\hline External debt $5 /$ & 44.3 & 47.8 & 87.2 & 98.3 & 95.6 & 94.2 \\
\hline Of which: External public debt & 30.3 & 31.4 & 68.9 & 85.3 & 82.3 & 82.2 \\
\hline Gross official reserves (US\$ millions) & 2,779 & 3,099 & 776 & 2,087 & 2,779 & 2,750 \\
\hline In months of imports of goods and services & 8.0 & 10.0 & 3.8 & 9.2 & 11.3 & 9.9 \\
\hline As percent of short-term debt $5 /$ & 108.9 & 114.7 & 31.8 & 105.8 & 137.0 & 137.4 \\
\hline As percent of short-term debt plus all FX deposits & 18.2 & 18.0 & 7.7 & 21.4 & $\ldots$ & 26.1 \\
\hline $\begin{array}{l}\text { Banking system foreign reserves as percent of short- } \\
\text { term debt plus all FX deposits }\end{array}$ & 59.2 & 60.3 & 48.5 & 59.6 & $\ldots$ & 65.0 \\
\hline REER (percentage depreciation -, e.o.p.) & -0.9 & -5.4 & -13.2 & -15.0 & $\cdots$ & ... \\
\hline
\end{tabular}

Sources: Data provided by the Uruguayan authorities; and Fund staff estimates.

1/ Evaluated at program exchange rates for 2004.

2/ Part of the sharp drop in 2003 is due to the removal of the three liquidated banks from the database in May 2003.

3/ Defined as changes in reserve assets.

4/ Defined for combined public sector.

5/ Excludes nonresident deposits. 


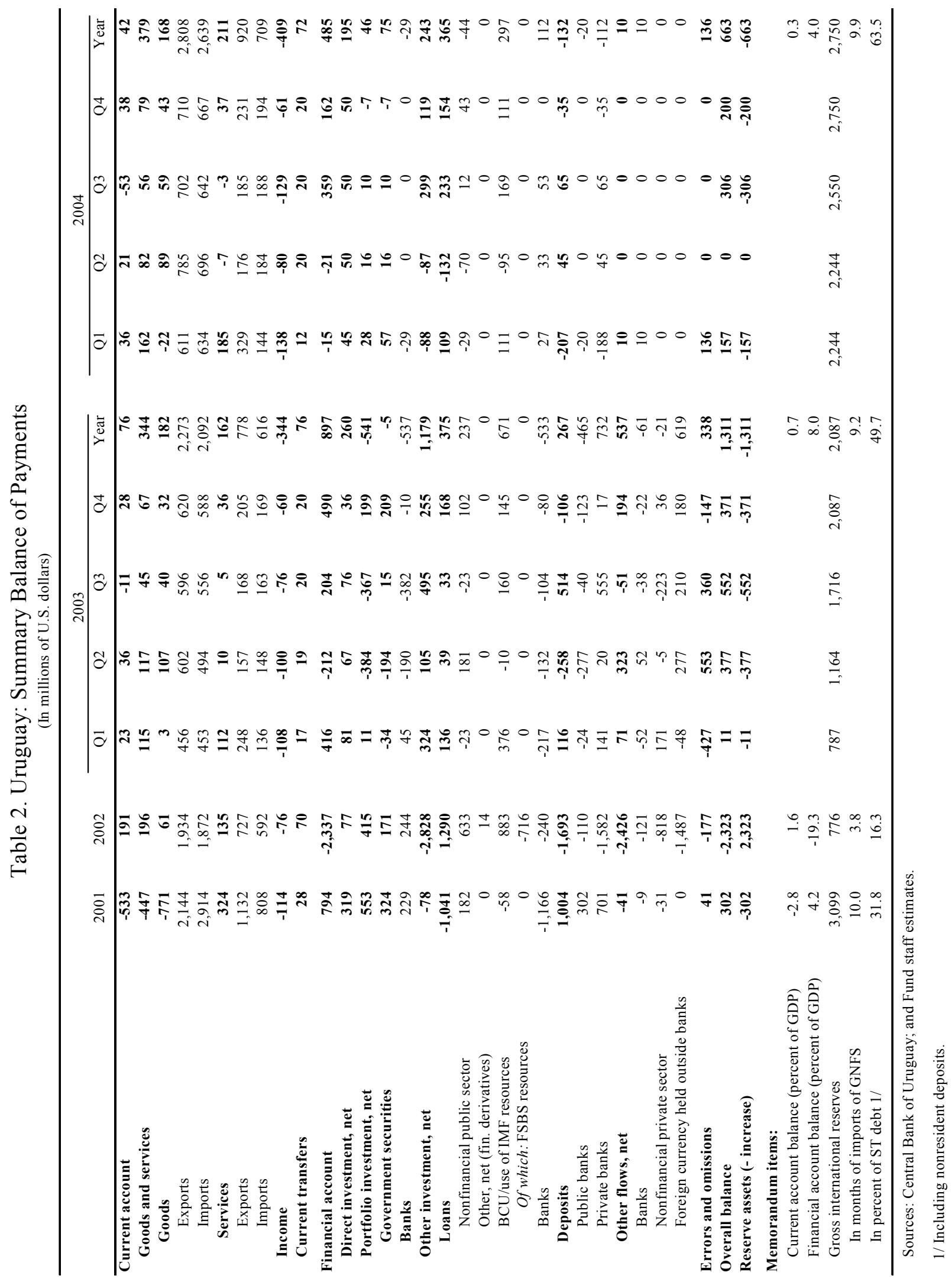


Table 3. Uruguay: Performance Under the 2004 Economic Program 1/

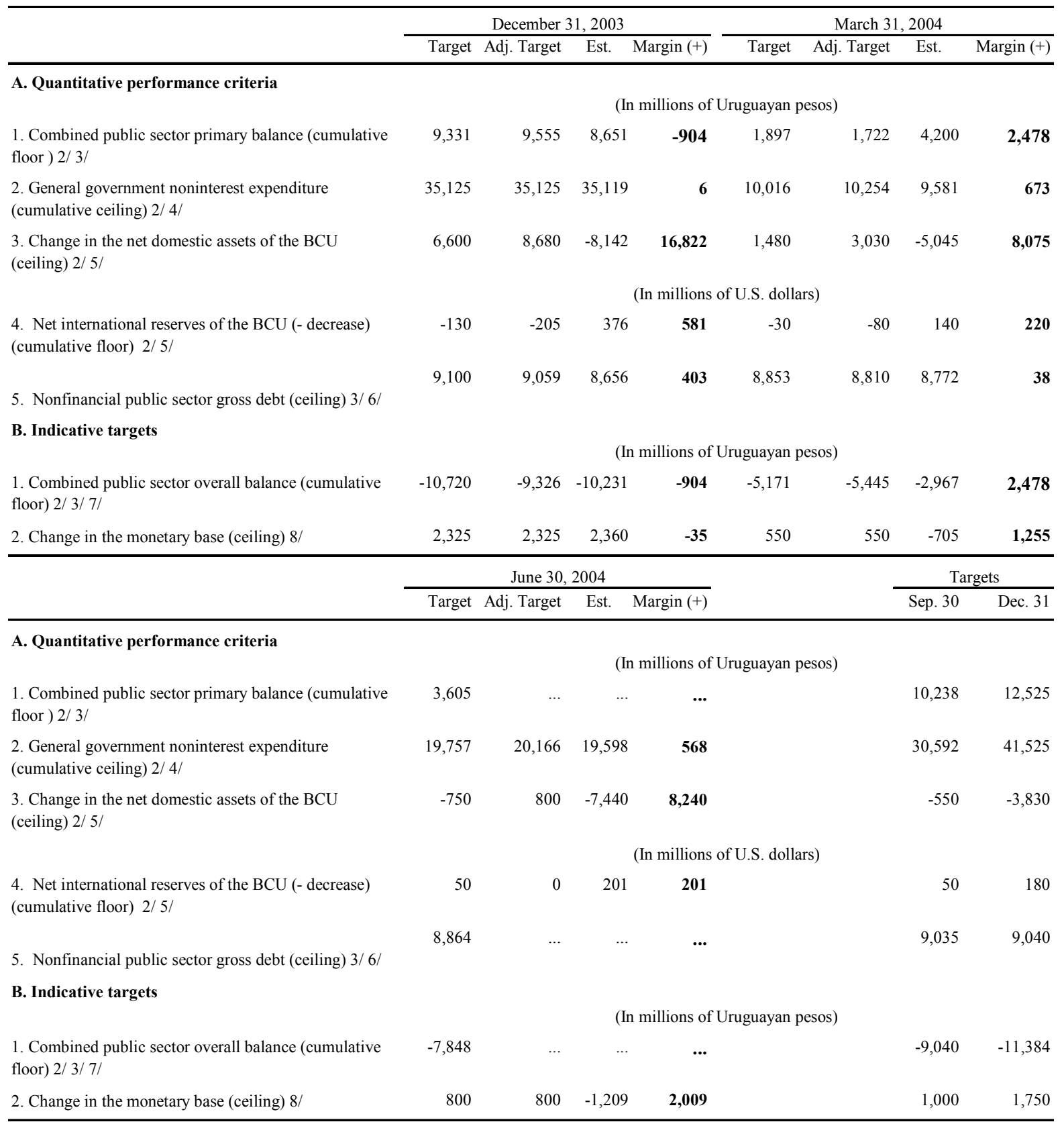

Sources: Ministry of Economy and Finance; and Central Bank of Uruguay.

$1 /$ As defined in the attached Technical Memorandum of Understanding.

2/ Cumulative changes from end-December 2002 for 2003; and from end-December 2003 for 2004.

3/ Adjusted upward/downward for changes in social security contributions, as defined in the TMU.

4/ Adjusted upward/downward for changes in collections of Fondos de Libre Disponibilidad (FLD), as defined in the TMU.

5/ Adjusted upward/downward for changes in program disbursements from the World Bank and IDB, as defined in the TMU.

6/ All maturities. The 2002 base includes US\$294 million of unsecuritized debt arising from an agreement between the MEF and BROU.

The 2003 base includes all loans guaranteed by the government. For December 2003, the debt ceiling has been adjusted upward to reflect the transfer of Brady bonds from the central bank to the government.

7/ Adjusted upward/downward for changes in interest payments, as defined in the TMU.

8/ Cumulative change from December 2002 average for 2003; from December 2003 average for 2004. 
Table 3. Uruguay: Performance Under the 2004 Economic Program (concluded)

\begin{tabular}{|c|c|c|}
\hline & Date & Status \\
\hline \multicolumn{3}{|l|}{ C. Structural performance criteria } \\
\hline Selection of winning bid for outsourcing of assets of liquidated banks & End-March & $\begin{array}{l}\text { Not observed; reset } \\
\text { as a prior action for } \\
\text { the Fifth Review }\end{array}$ \\
\hline $\begin{array}{l}\text { General manager of BROU's fiduciary trust to enter into contract for the specialized services } \\
\text { of professionals experienced in dealing with nonperfoming loans }\end{array}$ & End-March & $\begin{array}{l}\text { Observed with slight } \\
\text { delay }\end{array}$ \\
\hline $\begin{array}{l}\text { Completion of the transfer to the fiduciary trust of all Category } 4 \text { nonperforming loans above } \\
\text { US } \$ 100,000 \text { (more than } 150 \text { days overdue) that have become Category } 5 \text { (more than } 240 \text { days } \\
\text { overdue) }\end{array}$ & End-March & Observed \\
\hline $\begin{array}{l}\text { Completion of the transfer to the fiduciary trust of all Category } 4 \text { and } 5 \text { loans above } \\
\text { US } \$ 50,000\end{array}$ & End-June & Observed \\
\hline Government to ensure timely service of BHU note to BROU & Continuous & Observed \\
\hline \multicolumn{3}{|l|}{ D. Structural benchmarks } \\
\hline Completion of supplementary external audit of FSBS. & End-March & Ongoing \\
\hline $\begin{array}{l}\text { Completion of external audit by an internationally reputable firm of assets transferred to the } \\
\text { fiduciary trust. }\end{array}$ & End-June & $\begin{array}{l}\text { Pending, audit } \\
\text { underway }\end{array}$ \\
\hline Approval by Congress of the reform of pension funds for the police and the military. & End-June & $\begin{array}{l}\text { Not observed; reset } \\
\text { to end-December }\end{array}$ \\
\hline Completion of external audit of BCU's 2003 accounts. & End-June & Observed \\
\hline
\end{tabular}

Sources: Ministry of Economy and Finance; and Central Bank of Uruguay. 


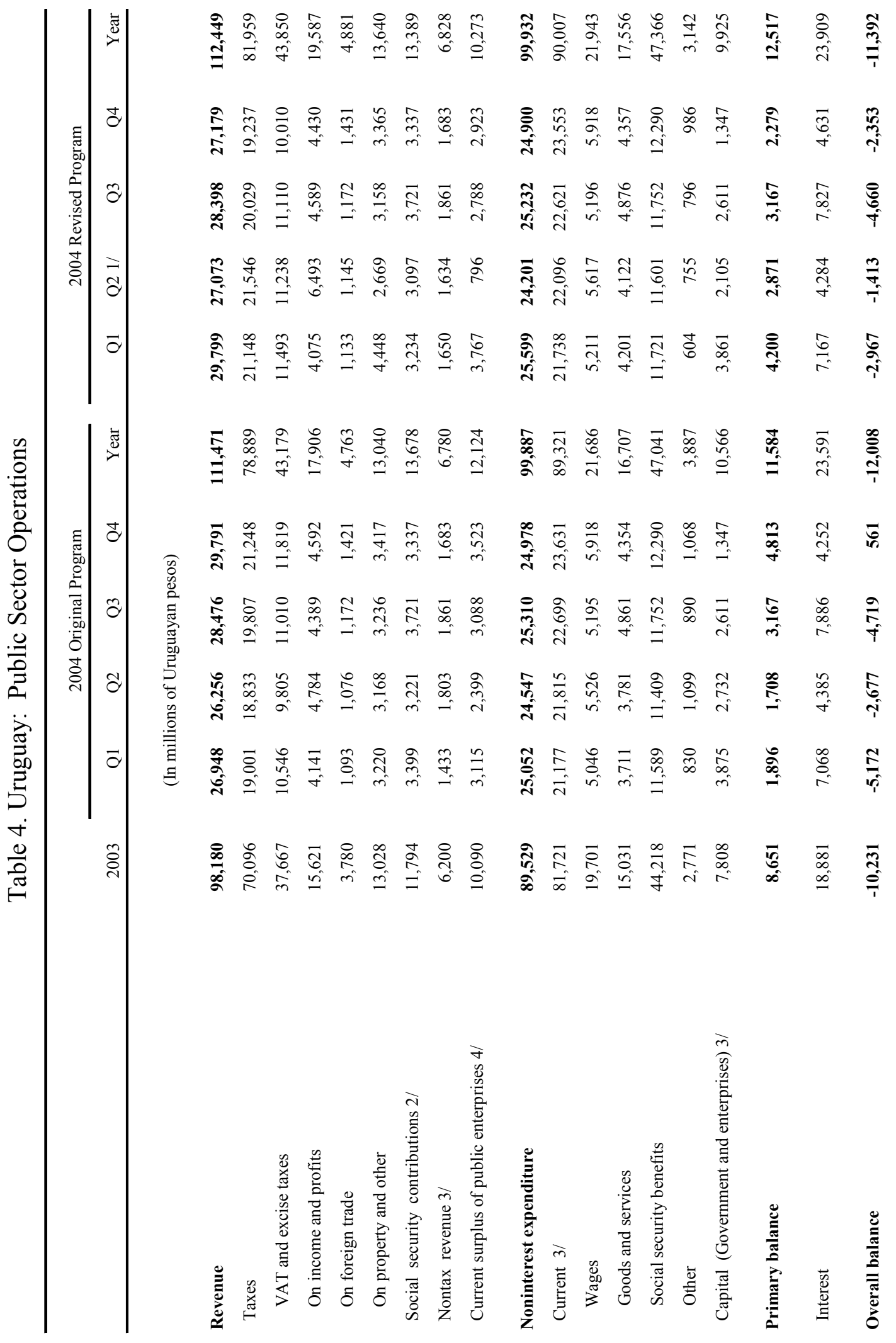




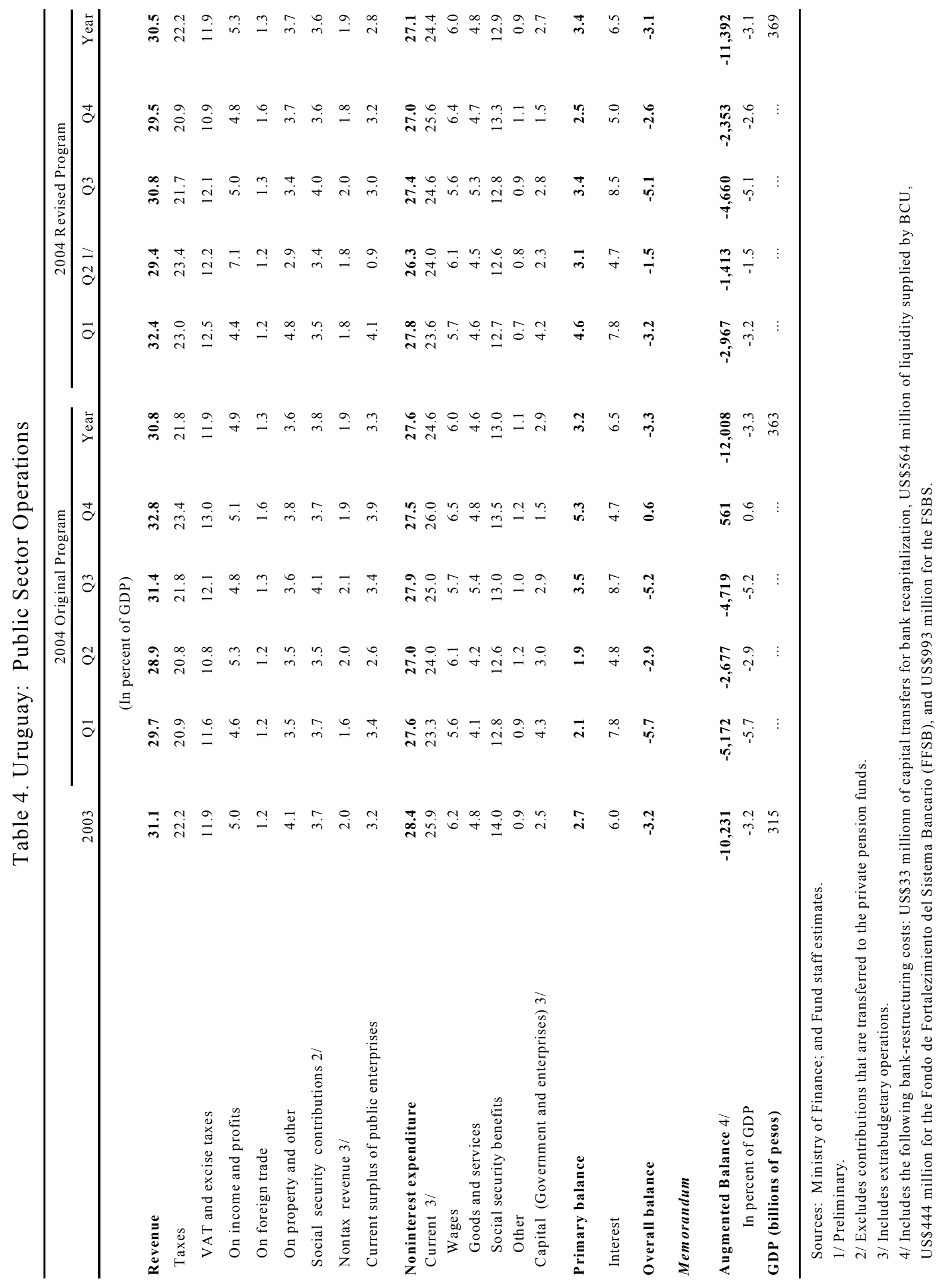




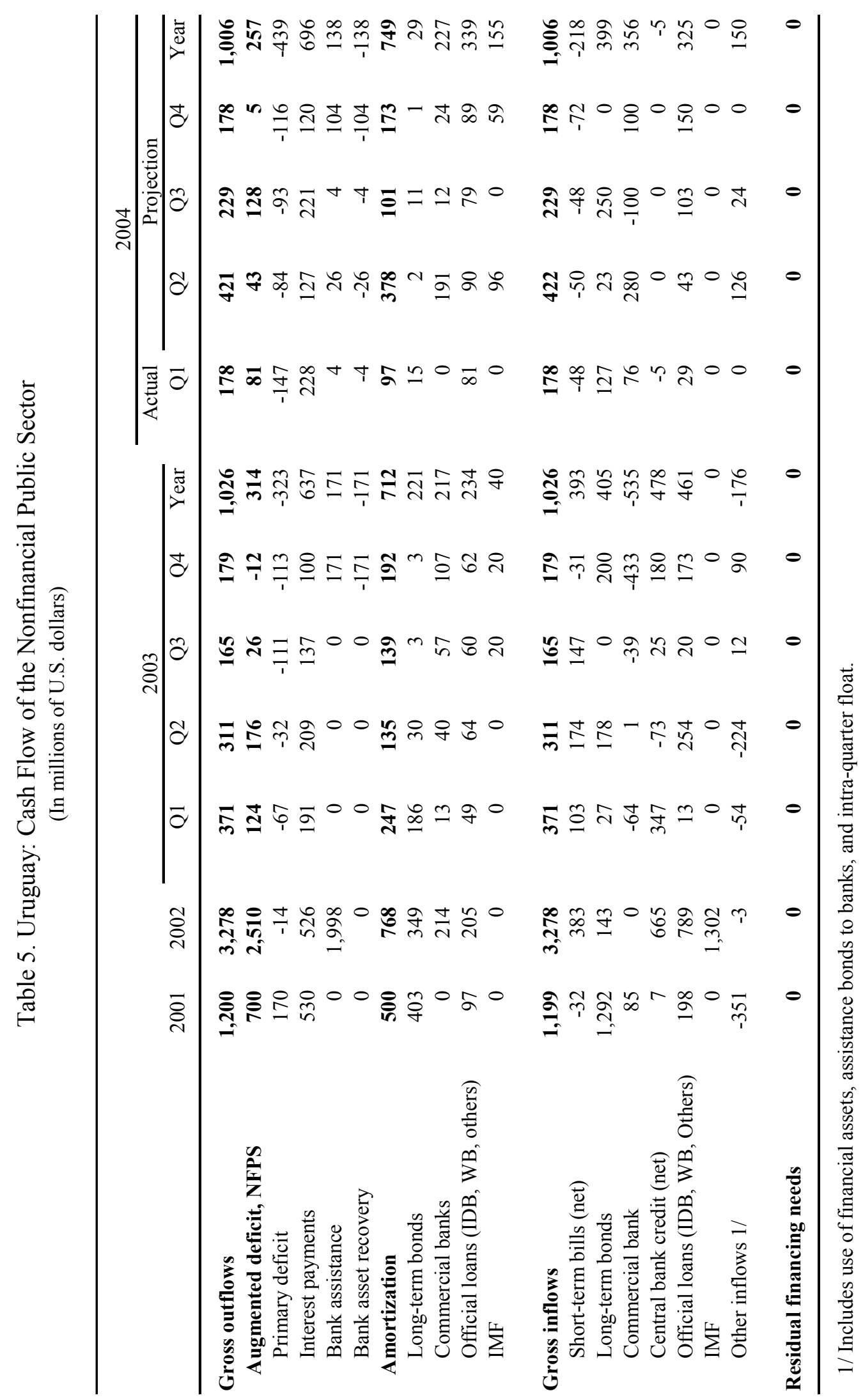


Table 6. Uruguay: Summary Accounts of the Banking System 1/ (In millions of Uruguayan pesos, unless otherwise indicated)

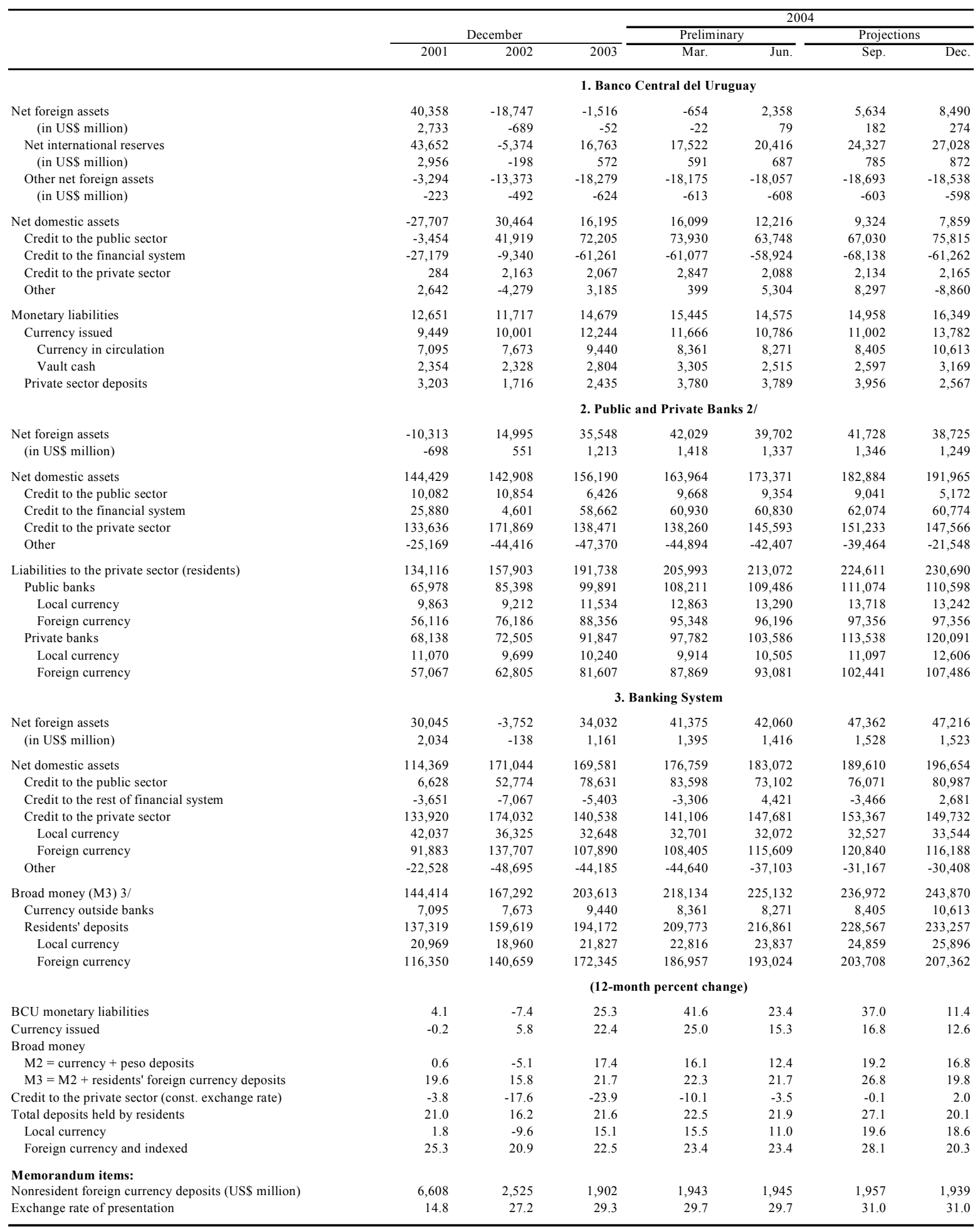

Sources: Central Bank of Uruguay; and Fund staff estimates.

1/ Presentation used for program monitoring. May differ from presentation and definitions used in IFS

2/ The Banco de la Republica Oriental de Uruguay (BROU), Banco Hipotecario de Uruguay (BHU; mortgage institution), private banks, and cooperatives.

3/ Excludes nonresident deposits. 
Table 7. Uruguay: Medium-Term Outlook

\begin{tabular}{|c|c|c|c|c|c|c|c|}
\hline & \multirow[b]{2}{*}{2002} & \multirow[b]{2}{*}{2003} & \multicolumn{5}{|c|}{ Projections } \\
\hline & & & 2004 & 2005 & 2006 & 2007 & 2008 \\
\hline \multicolumn{8}{|c|}{$\begin{array}{l}\text { 1. Output and prices } \\
\text { (In percent change) }\end{array}$} \\
\hline Real GDP & -11.0 & 2.5 & 7.0 & 4.0 & 4.0 & 3.0 & 3.0 \\
\hline Real domestic demand & -18.1 & 1.6 & 8.0 & 4.8 & 4.9 & 3.5 & 3.5 \\
\hline Of which : consumption & -15.7 & -1.1 & 8.3 & 3.4 & 3.3 & 2.4 & 2.3 \\
\hline Consumer prices (end-of-period) & 25.9 & 10.2 & 9.0 & 7.5 & 7.0 & 6.5 & 4.7 \\
\hline Merchandise export prices & -7.9 & 9.0 & 7.0 & 0.0 & 0.0 & 0.0 & 0.0 \\
\hline Merchandise export volume & -3.3 & 7.1 & 15.4 & 6.0 & 6.0 & 5.0 & 5.0 \\
\hline Merchandise import prices & -12.1 & 4.0 & 6.3 & 0.0 & 0.0 & 0.0 & 0.0 \\
\hline Merchandise import volume & -26.4 & 2.5 & 18.8 & 8.0 & 8.0 & 6.0 & 6.0 \\
\hline Merchandise terms of trade & 4.8 & 3.3 & 0.3 & 0.0 & 0.0 & 0.0 & 0.0 \\
\hline \multicolumn{8}{|c|}{$\begin{array}{l}\text { 2. Savings and investment } \\
\text { (In percent of GDP) }\end{array}$} \\
\hline Gross domestic investment & 11.5 & 13.1 & 12.5 & 13.3 & 14.2 & 14.8 & 15.4 \\
\hline Gross national savings & 13.1 & 13.7 & 12.8 & 13.8 & 14.4 & 14.3 & 14.3 \\
\hline Foreign savings & -1.6 & -0.7 & -0.3 & -0.5 & -0.2 & 0.5 & 1.2 \\
\hline \multicolumn{8}{|c|}{$\begin{array}{l}\text { 3. Combined public sector operations } \\
\text { (In percent of GDP) }\end{array}$} \\
\hline Overall balance & -4.6 & -3.2 & -3.1 & -2.0 & -1.9 & -1.9 & -2.1 \\
\hline Primary balance & 0.0 & 2.7 & 3.4 & 3.5 & 3.7 & 3.8 & 3.8 \\
\hline Public sector debt & 93.8 & 108.2 & 102.7 & 96.9 & 89.6 & 84.7 & 81.7 \\
\hline \multicolumn{8}{|c|}{ 4. Reserve adequacy } \\
\hline \multicolumn{8}{|l|}{ Gross official reserves } \\
\hline In months of imports of goods and services & 3.8 & 9.3 & 9.9 & 9.7 & 8.6 & 7.9 & 7.2 \\
\hline \multicolumn{8}{|l|}{ In percent of short-term debt } \\
\hline excluding nonresident deposits & 31.8 & 105.8 & 137.4 & 142.2 & 134.1 & 129.5 & 125.0 \\
\hline including nonresident deposits & 16.3 & 49.7 & 63.5 & 64.3 & 58.7 & 54.6 & 50.8 \\
\hline \multicolumn{8}{|c|}{$\begin{array}{l}\text { 5. Balance of payments and other external indicators } \\
\text { (In millions of U.S. dollars) }\end{array}$} \\
\hline Current account balance & 191 & 76 & 42 & 62 & 31 & -76 & -195 \\
\hline Trade balance & 61 & 182 & 168 & 126 & 76 & 49 & 19 \\
\hline Exports, f.o.b. & 1,934 & 2,273 & 2,808 & 2,976 & 3,155 & 3,313 & 3,478 \\
\hline Imports, f.o.b. & 1,872 & 2,092 & 2,639 & 2,851 & 3,079 & 3,263 & 3,459 \\
\hline Nonfactor services & 135 & 162 & 211 & 210 & 207 & 216 & 218 \\
\hline Exports, f.o.b. & 727 & 778 & 920 & 975 & 1,034 & 1,093 & 1,147 \\
\hline Imports, f.o.b. & 592 & 616 & 709 & 766 & 827 & 877 & 929 \\
\hline Factor services (net) & -76 & -344 & -409 & -353 & -332 & -422 & -512 \\
\hline Transfers (net) & 70 & 76 & 72 & 80 & 80 & 80 & 80 \\
\hline Financial account & $-2,337$ & 897 & 485 & 99 & -144 & -5 & 113 \\
\hline Foreign direct investment, net & 77 & 260 & 195 & 200 & 250 & 250 & 250 \\
\hline Portfolio investment, net & 415 & -541 & 46 & 83 & -89 & 81 & 20 \\
\hline Other investment, net & $-2,828$ & 1,179 & 243 & -184 & -306 & -336 & -158 \\
\hline Errors and omissions & -177 & 338 & 136 & 0 & 0 & 0 & 0 \\
\hline Overall balance & $-2,323$ & 1,311 & 663 & 162 & -114 & -82 & -82 \\
\hline Reserve assets (- increase) & 2,323 & $-1,311$ & -663 & -162 & 114 & 82 & 82 \\
\hline \multicolumn{8}{|c|}{ (In percent of GDP) } \\
\hline Current account balance & 1.6 & 0.7 & 0.3 & 0.5 & 0.2 & -0.5 & -1.2 \\
\hline Financial account & -19.3 & 8.0 & 4.0 & 0.8 & -1.0 & 0.0 & 0.7 \\
\hline Total external debt (excl. nonres. deposits) & 87.2 & 98.3 & 94.2 & 86.6 & 74.0 & 65.7 & 58.7 \\
\hline \multicolumn{8}{|c|}{ (In percent of exports of goods and nonfactor services) } \\
\hline Total external debt (excl. nonres. deposits) & 397.6 & 360.9 & 308.7 & 289.8 & 258.6 & 236.7 & 214.7 \\
\hline Total external debt (incl. nonres. deposits) & 485.1 & 434.0 & 371.2 & 352.5 & 322.6 & 302.0 & 281.2 \\
\hline Debt service & 55.6 & 50.7 & 40.0 & 43.3 & 48.2 & 38.5 & 29.4 \\
\hline Of which: interest & 25.7 & 17.2 & 14.3 & 16.0 & 17.7 & 18.8 & 19.3 \\
\hline
\end{tabular}

Sources: Central Bank of Uruguay; and Fund staff estimates. 


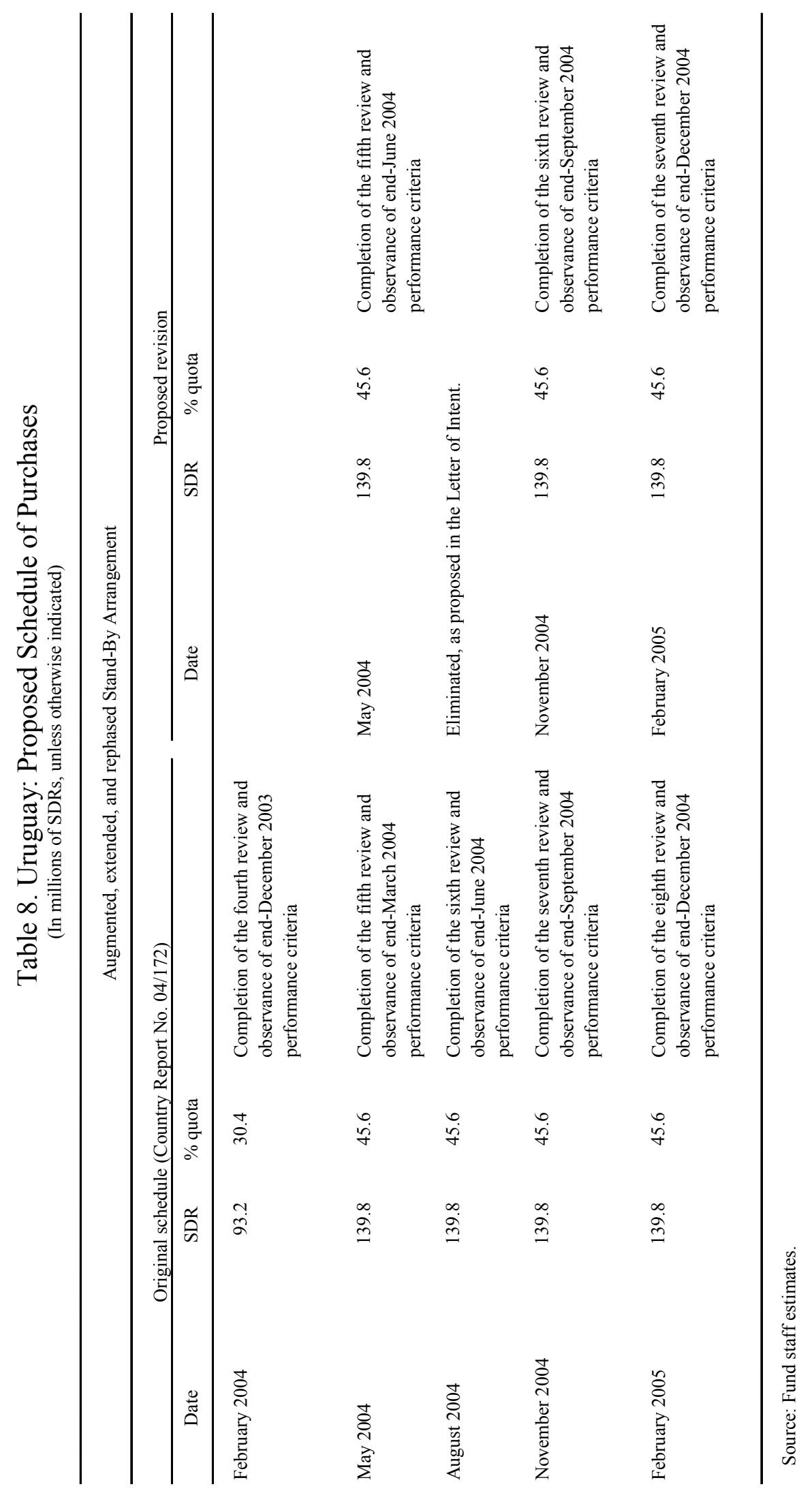


Table 9. Uruguay: Projected Payments to the Fund and Indicators of Capacity to Repay the Fund 1/

\begin{tabular}{|c|c|c|c|c|c|c|c|}
\hline & 2003 & 2004 & 2005 & 2006 & 2007 & 2008 & 2009 \\
\hline \multicolumn{8}{|c|}{ Cumulative payments (existing and prospective; in SDR million) } \\
\hline Principal (repurchases) & 57.1 & 128.7 & 226.6 & 666.7 & 574.4 & 320.8 & 203.9 \\
\hline Charges and interest $2 /$ & 46.6 & 65.5 & 84.7 & 65.2 & 31.1 & 13.6 & 5.0 \\
\hline On Fund credit & 45.9 & 64.9 & 84.1 & 64.6 & 30.5 & 13.0 & 4.4 \\
\hline On use of SDRs & 0.7 & 0.6 & 0.6 & 0.6 & 0.6 & 0.6 & 0.6 \\
\hline Total obligations & 103.0 & 193.6 & 311.3 & 731.9 & 605.5 & 334.3 & 208.9 \\
\hline (percent of quota) & 33.6 & 63.2 & 101.6 & 238.8 & 197.6 & 109.1 & 68.2 \\
\hline \multicolumn{8}{|l|}{ Fund repurchases and charges } \\
\hline In millions of SDRs & 103.0 & 193.6 & 311.3 & 731.9 & 605.5 & 334.3 & 208.9 \\
\hline In millions of U.S. dollars & 144.0 & 285.5 & 459.6 & $1,083.5$ & 898.2 & 496.4 & 310.3 \\
\hline In percent of exports of goods and NFS & 4.7 & 7.7 & 11.6 & 25.9 & 20.4 & 10.7 & 6.4 \\
\hline In percent of GDP & 1.3 & 2.3 & 3.5 & 7.4 & 5.6 & 2.9 & 1.7 \\
\hline In percent of quota & 33.6 & 63.2 & 101.6 & 238.8 & 197.6 & 109.1 & 68.2 \\
\hline In percent of overall external debt service & 9.3 & 19.1 & 26.9 & 53.7 & 53.0 & 36.5 & 24.4 \\
\hline In percent of gross reserves $1 /$ & 6.9 & 10.4 & 15.8 & 38.7 & 33.1 & 18.8 & 11.8 \\
\hline \multicolumn{8}{|l|}{ Fund credit outstanding (end of period) } \\
\hline In millions of SDRs & $1,625.9$ & $1,870.0$ & $1,783.2$ & $1,116.5$ & 542.1 & 221.4 & 17.5 \\
\hline In millions of U.S. dollars & $2,416.0$ & $2,753.8$ & $2,635.9$ & $1,654.6$ & 804.5 & 328.7 & 26.0 \\
\hline In percent of exports of goods and NFS & 79.2 & 73.9 & 66.7 & 39.5 & 18.3 & 7.1 & 0.5 \\
\hline In percent of GDP & 21.6 & 22.6 & 19.9 & 11.3 & 5.1 & 1.9 & 0.1 \\
\hline In percent of quota & 530.5 & 610.1 & 581.8 & 364.3 & 176.9 & 72.2 & 5.7 \\
\hline In percent of public sector external debt & 25.3 & 27.5 & 26.5 & 17.8 & 9.0 & 3.9 & 0.3 \\
\hline In percent of overall external debt & 21.9 & 23.9 & 23.0 & 15.3 & 7.7 & 3.3 & 0.2 \\
\hline In percent of gross reserves & 115.8 & 100.1 & 90.5 & 59.1 & 29.6 & 12.5 & 1.0 \\
\hline \multicolumn{8}{|c|}{ Memorandum items (in millions of U.S. dollars unless otherwise noted): } \\
\hline Exports of goods and NFS & 3,051 & 3,728 & 3,952 & 4,189 & 4,405 & 4,625 & 4,857 \\
\hline Quota (millions of SDRs) & 306.5 & 306.5 & 306.5 & 306.5 & 306.5 & 306.5 & 306.5 \\
\hline GDP & 11,202 & 12,190 & 13,220 & 14,677 & 15,910 & 16,952 & 17,843 \\
\hline U.S. dollar per SDR, e.o.p. & 1.49 & 1.47 & 1.48 & 1.48 & 1.48 & 1.48 & 1.49 \\
\hline U.S. dollar per SDR, average & 1.40 & 1.47 & 1.48 & 1.48 & 1.48 & 1.48 & 1.49 \\
\hline Public sector debt & 12,119 & 12,539 & 12,818 & 13,119 & 13,447 & 13,817 & 14,200 \\
\hline Public sector external debt & 9,557 & 10,024 & 9,948 & 9,313 & 8,921 & 8,439 & 9,172 \\
\hline Overall external debt service & 1,548 & 1,492 & 1,710 & 2,019 & 1,696 & 1,361 & 1,272 \\
\hline Of which: public debt service to all IFIs & 387 & 628 & 911 & 1,631 & 1,389 & 746 & 549 \\
\hline Overall external debt & 11,012 & 11,508 & 11,453 & 10,833 & 10,425 & 9,929 & 10,647 \\
\hline Gross foreign reserves & 2,087 & 2,750 & 2,911 & 2,798 & 2,716 & 2,634 & 2,630 \\
\hline
\end{tabular}

Sources: Finance Department; and Fund staff estimates and projections.

1/ Assuming that all scheduled purchases are made and that repurchases under the SBA and SRF are made on an obligations basis. On March 17, 2003, the IMF Executive Board converted the two remaining SRF repurchases to an obligations basis. On February 20, 2004 , the IMF Executive Board converted SBA repurchases falling due in 2003 to an obligations basis.

2/ Projections are based on current rates of charge, including burden-sharing where applicable, for purchases in the GRA. The current SDR interest rate is assumed for net use of SDRs. 
Table 10. Uruguay: Vulnerability Indicators

\begin{tabular}{|c|c|c|c|c|c|}
\hline & 2000 & 2001 & 2002 & 2003 & $\begin{array}{l}\text { Proj. } \\
2004\end{array}$ \\
\hline & \multicolumn{5}{|c|}{ (Percent change, unless otherwise indicated) } \\
\hline \multicolumn{6}{|l|}{ Financial sector indicators } \\
\hline Broad money & 10.2 & 19.6 & 15.8 & 21.7 & 19.8 \\
\hline Credit to the private sector (const. exch. rate) & 0.3 & -3.8 & -17.6 & -23.9 & 2.0 \\
\hline Share of nonperforming loans in total loans (in percent) $1 /$ & 16.4 & 17.9 & 38.0 & 16.5 & 9.6 \\
\hline Interbank interest rates (percent, end of period) $2 /$ & 17.5 & 42.7 & 45.0 & 2.5 & 2.0 \\
\hline Public debt (percent of GDP) & 45.5 & 53.8 & 93.8 & 108.2 & 102.7 \\
\hline \multicolumn{6}{|l|}{ External indicators } \\
\hline Merchandise exports & 4.1 & -10.1 & -9.8 & 17.6 & 23.5 \\
\hline Merchandise imports & 3.9 & -12.0 & -35.8 & 11.7 & 26.2 \\
\hline Merchandise terms of trade & -6.6 & -0.7 & 4.8 & 3.3 & 0.3 \\
\hline \multirow[t]{2}{*}{ REER appreciation $(+) 3 /$} & -0.9 & -5.4 & -13.2 & -15.0 & 5.5 \\
\hline & \multicolumn{5}{|c|}{ (Percent of GDP, unless otherwise indicated) } \\
\hline Current account balance & -2.8 & -2.8 & 1.6 & 0.7 & 0.3 \\
\hline Capital and financial account balance & 3.8 & 4.2 & -19.3 & 8.0 & 4.0 \\
\hline Of which: Net foreign direct investment & 1.4 & 1.7 & 0.6 & 2.3 & 1.6 \\
\hline Portfolio investment (securities, etc.) & 1.5 & 3.0 & 3.4 & -4.8 & 0.4 \\
\hline Other net inflows (deposits, loans, trade credits, etc.) & 1.0 & -0.4 & -23.3 & 10.5 & 2.0 \\
\hline Total external debt including nonresident deposits & 72.7 & 85.3 & 106.4 & 118.2 & 113.3 \\
\hline Of which: Public sector excl. nonresident deposits & 30.3 & 31.4 & 68.9 & 85.3 & 82.2 \\
\hline Foreign currency deposits (nonresidents) & 28.4 & 37.6 & 19.3 & 19.9 & 19.1 \\
\hline In percent of exports GNFS & 399.1 & 43.4 & 55.6 & 50.7 & 40.0 \\
\hline Total external debt excluding nonresident deposits & 44.3 & 47.8 & 87.2 & 98.3 & 94.2 \\
\hline In percent of exports GNFS & 243.0 & 487.4 & 485.1 & 434.0 & 371.2 \\
\hline External interest payments to exports GNFS (in percent) & 21.7 & 23.7 & 25.7 & 17.2 & 14.3 \\
\hline \multirow[t]{2}{*}{ External amortization payments to exports GNFS (in percent) } & 14.4 & 19.7 & 29.9 & 33.5 & 25.7 \\
\hline & \multicolumn{5}{|c|}{ (US million, unless otherwise indicated) } \\
\hline Central Bank reserve liabilities 2/ & 150 & 144 & 970 & 1,515 & 1,639 \\
\hline Short term foreign assets of the financial sector $4 /$ & 7,367 & 7,695 & 3,140 & 4,989 & 5,348 \\
\hline Short term foreign liabilities of the financial sector 4 / & 6,504 & 7,547 & 4,101 & 3,530 & 1,925 \\
\hline Gross official reserves & 2,779 & 3,099 & 776 & 2,087 & 2,750 \\
\hline In months of imports GNFS & 8.0 & 10.0 & 3.8 & 9.2 & 9.9 \\
\hline In percent of total debt service & 210.2 & 350.9 & 122.5 & 447.1 & 572.8 \\
\hline In percent of broad money & 27.8 & 28.6 & 10.0 & 29.9 & 35.1 \\
\hline In percent of base money & 365.9 & 483.0 & 203.8 & 415.1 & 523.6 \\
\hline In percent of short-term external debt incl. nonres FX deposits 5/ & 33.6 & 31.8 & 16.3 & 49.7 & 63.5 \\
\hline In percent of short-term external debt excl. nonres FX deposits 5/ & 33.6 & 31.8 & 16.3 & 49.7 & 63.5 \\
\hline In percent of short-term external debt plus all FX deposits 5/ & 18.2 & 18.0 & 7.7 & 21.4 & 26.1 \\
\hline $\begin{array}{l}\text { Banking system foreign assets as percent of short-term external debt } \\
\text { plus all FX deposits } 5 /\end{array}$ & 59.2 & 60.3 & 48.5 & 59.6 & 65.0 \\
\hline \multicolumn{6}{|l|}{ Financial market indicators } \\
\hline Foreign currency debt rating (Moody's) 2/ & Baa3 & Baa3 & B3 & B3 & B3 \\
\hline Foreign currency debt rating (S\&P) 2/ & BBB- & BBB- & B- & B- & $\mathrm{B}$ \\
\hline EMBI secondary market spread (bps, end of period) $2 /$ & 290 & 284 & 1,228 & 624 & 594 \\
\hline Exchange rate (per U.S. dollar, period average) 2/ & 12.1 & 13.3 & 21.6 & 29.2 & 29.5 \\
\hline
\end{tabular}

Sources: Central Bank of Uruguay; and Fund staff estimates.

1/ For 2004, end-March.

2/ For 2004, mid-August.

3/ For 2004, end-May.

4/ For 2004, end-April.

5 / By remaining maturity. 


\section{URUGUAY-FUND RELATIONS}

(As of June 30, 2004)

I. Membership Status: Joined March 11, 1946; Article VIII

\section{Financial Relations}

II. General Resources Account:

$\begin{array}{rr}\begin{array}{rr}\text { In millions } \\ \text { of SDRs }\end{array} & \begin{array}{r}\text { In percent } \\ \text { of Quota }\end{array} \\ 306.50 & 100.0 \\ 1,961.26 & 660.88 \\ 0.0 & 0.0\end{array}$

III. SDR Department:

In millions Percent of

Quota

Fund holdings of currency

of SDRs

$\underline{\text { Allocation }}$

Net cumulative allocation

49.98

100.0

Holdings

2.70

5.40

IV. Outstanding Purchases and Loans:

In millions

In percent of SDRs of quota

Stand-by arrangements

$1,654.75$

539.89

V. Financial Arrangements:

Type

Stand-by

Of which SRF

Stand-by

Stand-by $\underline{\text { SDR Millions }}$

\begin{tabular}{|c|c|c|c|}
\hline \multirow{3}{*}{$\begin{array}{r}\text { Approval } \\
\text { Date }\end{array}$} & \multicolumn{3}{|c|}{$\underline{\text { SDR Millions }}$} \\
\hline & Expiration & Amount & Amount \\
\hline & Date & Approved & Drawn \\
\hline & & 2,1 & 1,56 \\
\hline & $8 / 08 / 02$ & 128.70 & 128.70 \\
\hline & $3 / 31 /$ & 150.00 & 150.00 \\
\hline 3/29/99 & $3 / 28 / 00$ & 70.00 & 0.00 \\
\hline
\end{tabular}

VI. Projected Obligations to Fund: (Obligation Basis) (SDR millions; based on existing use of resources and present holdings of SDRs):

Forthcoming

\begin{tabular}{rrrrr}
\hline 2004 & 2005 & 2006 & 2007 & 2008 \\
\hline 64.35 & 226.63 & 666.65 & 556.92 & 128.55 \\
34.44 & 63.12 & 42.81 & 14.81 & 3.26 \\
\hline 98.79 & 289.75 & 709.46 & 571.73 & 131.81
\end{tabular}

Principal

Charges/interest

Total 


\section{E. Nonfinancial Relations}

VII. Safeguards Assessment: An on-site assessment of the BCU was conducted in July 2002, and the final safeguards assessment report was approved by Fund Management in January 2003. The assessment identified a need to strengthen the control and oversight framework within the BCU, in particular in the external audit area. To this end, staff recommended the establishment of an audit committee, the hiring of a private audit firm with international affiliation to perform a financial audit of the BCU, and the establishment of similar external audit procedures for the FSBS. The authorities committed to the implementation of all the safeguards recommendations. An external audit of the FSBS was completed on September 30, 2003, and a supplementary external audit is in progress. An external audit of the BCU's 2003 accounts has been completed.

VIII. Exchange Rate Arrangement: The currency is the Uruguayan peso (Ur\$). Uruguay has followed an independently floating exchange rate regime since July 29, 2002. On August 4, 2004, buying and selling interbank rates for the U.S. dollar, the intervention currency, were Ur\$29.20 and Ur\$29.25, respectively. Uruguay's exchange system is mostly free of restrictions on payments and transfers for current international transactions. However, the reprogramming of time deposits at BROU and BHU gives rise to an exchange restriction under Article VIII, as it prevents nonresidents affected by the reprogramming from transferring abroad proceeds of recent current international transactions. Staff has recommended approval of the exchange restriction, given that it is temporary and does not discriminate among Fund members.

IX. Article IV Consultation: The 2003 Article IV consultation was concluded by the Executive Board on July 11 (Country Report No. 03/247). Uruguay is on the standard consultation cycle governed by the provisions approved by the Executive Board on July 15, 2002.

X. FSAP participation, ROSCs, and OFC Assessments: The ROSC-module on fiscal transparency was published on March 5, 2000. A ROSC-module on data dissemination practices was published on October 18, 2001. An FSAP exercise was started in November 2001, but was subsequently suspended on account of the financial crisis in 2002.

XI. Technical Assistance: Technical assistance in tax policy and tax administration was provided by FAD in May and July 2003. In April 2003, STA provided technical assistance on adequate recording of loans funded by the FSBS. MFD has been providing substantial technical assistance since 2002 in the resolution of intervened banks and the restructuring of the public bank BROU.

XII. Resident Representative: Mr. Andreas Bauer 


\section{RELATIONS WITH THE WORLD BANK GROUP}

The Board considered the last Country Assistance Strategy (CAS) on May 5, 2000 and a CAS Progress Report on July 25, 2002. The Bank increased its financial support, shifting to a case lending scenario of US\$550 million for fiscal years 2002-04, concentrated in adjustment lending. A Structural Adjustment Loan (SAL 1) and a Special Structural Adjustment Loan (SSAL 1) were approved with the CAS PR, totaling US\$303 million, to assist Uruguay in addressing structural weaknesses and in managing the economic crisis. On April 8, 2003, another structural adjustment package (SAL 2 and SSAL 2) was approved totaling US\$252.5 million, focusing on improving public services and human development policies. Progress in implementation of SAL 1 and SSAL 1 has been satisfactory, and the last tranche release in the amount of US\$100 million (US\$50 of SAL 1 and US\$50 of SSAL 1) is expected for the first quarter of FY05. Progress in implementation of SAL 2 (public services) has been slow, as opposed to SSAL 2 (human development policies). Nevertheless, second and third tranche releases of both operations-that are linked- have been delayed. Approval of new investment operations was postponed in mid-CY02. A new CAS PR is being prepared for the transition period, and a new CAS will be prepared with the new administration that takes office in March 2005.

The investment portfolio comprises six projects totaling US\$289.5 million in commitments, with an undisbursed amount of US\$138.5 million as of June 28, 2004. Of the two structural adjustment packages, a total of US\$275 million remains to be disbursed. The last Investment Portfolio Performance Review took place in December 2003. At that time, the portfolio presented low levels of execution, mostly due to the fiscal constraints faced by Uruguay. However, implementation of the investment portfolio, measured in terms of percentages of budgetary execution and disbursement ratio, is now accelerating as the economic situation improves. 


\title{
FinANCIAL RELATIONS WITH THE WORLD BANK GROUP
}

(In millions of U.S. dollars)

Commitments

(Net of

Cancellations)

\author{
Disbursements
}

Undisbursed

Amount

$\begin{array}{lccr}\text { Agriculture } & 18.5 & 13.5 & 5.0 \\ \text { Central Government and Administration } & 555.6 & 280.6 & 275.0 \\ \text { Telecommunication } & 6.0 & 0.9 & 5.1 \\ \text { Education } & 42.0 & 7.0 & 35.0 \\ \text { Health } & 10.6 & 9.3 & 1.3 \\ \text { Power } & 125.0 & 77.4 & 47.6 \\ \text { Transportation } & 71.0 & 45.7 & 25.3 \\ \text { Water Supply } & 27.0 & 7.5 & 19.5 \\ \text { Total } & \mathbf{8 5 5 . 7} & \mathbf{4 4 1 . 9} & \mathbf{4 1 3 . 8}\end{array}$

I. IBRD Operations (as of June 28, 2004)

II. IFC Operations (as of May 31, 2004)

Held

Disbursed

$\begin{array}{rrrr}\text { Loans } & \text { Equity } & \text { Quasi } & \text { Participation } \\ 25.6 & 2.0 & 12.9 & 0.2 \\ 19.0 & 2.0 & 12.9 & 0.2\end{array}$

III. IBRD Loan Transactions (calendar year)

\begin{tabular}{lrrrrrrrrrr}
\hline & $\mathbf{1 9 9 5}$ & $\mathbf{1 9 9 6}$ & $\mathbf{1 9 9 7}$ & $\mathbf{1 9 9 8}$ & $\mathbf{1 9 9 9}$ & $\mathbf{2 0 0 0}$ & $\mathbf{2 0 0 1}$ & $\mathbf{2 0 0 2}$ & $\mathbf{2 0 0 3}$ & $\mathbf{2 0 0 4}^{\mathbf{1}}$ \\
\hline Disbursements & 31.7 & 38.7 & 50.4 & 143.9 & 66.3 & 134.2 & 64.7 & 233.5 & 97.4 & 21.7 \\
Repayments & 77.8 & 69.7 & 67.9 & 64.1 & 63.2 & 57.9 & 72.5 & 75.3 & 78.2 & 39.8 \\
& & & & & & & & & & \\
Net Lending & $\mathbf{- 4 6 . 1}$ & $\mathbf{- 3 1 . 0}$ & $\mathbf{- 1 7 . 5}$ & $\mathbf{7 9 . 8}$ & $\mathbf{3 . 1}$ & $\mathbf{7 6 . 3}$ & $\mathbf{- 7 . 8}$ & $\mathbf{1 5 8 . 2}$ & $\mathbf{1 9 . 2}$ & $\mathbf{- 8 . 1}$ \\
\hline
\end{tabular}

${ }^{1}$ As of June 14, 2004. 


\section{RELATIONS WITH THE INTER-AMERICAN DEVELOPMENT BANK}

The most recent IDB Country Strategy for Uruguay focuses on the following priority areas: (i) enhancing the regional and international competitiveness of domestic output and encouraging private investment, in order to foster healthy competition and allow for integration with both the regional and international markets; (ii) deepening the reform of the State, with a view to rationalizing expenditure, targeting interventions, and reducing its role in the production of domestic goods and services; and (iii) improving social welfare and increasing equity, particularly to those families and children living in poverty.

As of June 29, 2004 the Bank's active portfolio in Uruguay included 20 loans for the financing of investment projects; one sector loan, for strengthening the banking sector; and 30 nonreimbursable technical cooperation operations for US\$17 million. The lending portfolio amounts to US\$1,161 million, of which US\$487 million are pending disbursement. The IDB's preliminary lending program for 2004 includes financing for a cattle development program for US\$25 million; and a loan by the Private Sector Department under the trade financing facility (ABN-AMRO) for US\$12.5 million. The tentative lending program for 2005 includes a highway infrastructure program for US\$77 million; a program to support employment generation for US\$80 million; and a social sector program (policy-based loan), for an estimated US\$250 million.

\section{FINANCIAL RELATIONS WITH THE INTER-AMERICAN DEVELOPMENT BANK}

(In millions of U.S. dollars)

Total outstanding loans: US\$2,240.9 ${ }^{1}$

Loan transactions:

\begin{tabular}{lccccccc}
\hline & $\mathbf{1 9 9 7}$ & $\mathbf{1 9 9 8}$ & $\mathbf{1 9 9 9}$ & $\mathbf{2 0 0 0}$ & $\mathbf{2 0 0 1}$ & $\mathbf{2 0 0 2}$ & $\mathbf{2 0 0 3}$ \\
\hline Disbursements & 178.7 & 150.8 & 358.5 & 162.9 & 214.2 & 558.6 & 373.2 \\
Amortization & 45.7 & 48.3 & 57.0 & 59.4 & 60.7 & 73.1 & 103.2 \\
Net Loan Flows & $\mathbf{1 3 3 . 0}$ & $\mathbf{1 0 2 . 5}$ & $\mathbf{3 0 1 . 5}$ & $\mathbf{1 0 3 . 5}$ & $\mathbf{1 5 3 . 5}$ & $\mathbf{4 8 5 . 5}$ & $\mathbf{2 7 0 . 0}$ \\
\hline
\end{tabular}

Source: Inter-American Development Bank.

\footnotetext{
${ }^{1}$ As of May 31, 2004.
} 


\section{URUGUAY: STATISTICAL ISSUES}

1. The statistical database in Uruguay is generally adequate for the assessment and monitoring of macroeconomic policies, but important weaknesses exist, especially in the fiscal sector. A multisector mission of November 10-24, 1999 developed an action plan for bringing Uruguay's data dissemination policies and practices into line with the Fund's Special Data Dissemination Standard (SDDS), and on February 12, 2004, Uruguay subscribed to the SDSS. To improve the provision of fiscal data for program monitoring purposes, the government established recently a committee to bolster coordination between the MEF, the BCU, BROU, and BHU.

\section{Real sector}

National account statistics have a number of shortcomings, including the use of an outdated benchmark year 1983, limited coverage of the enterprise survey, long publication lags, inadequate information on the informal economy, and incomplete quarterly accounts. The BCU compiles and disseminates annual GDP estimates in current and constant prices by production and expenditure approach, as well as quarterly constant price GDP estimates by production and expenditure approach. Gross national income, gross disposable income and gross savings are also available annually. The November 1999 multisector mission recommended a range of improvements including the completion of the revision of data and methods that had already been partially carried out, introduction of annually chained volume measures, incorporation of new benchmark survey data, and compilation of quarterly estimates of GDP at current prices.

The authorities do not provide trade price and volume indices for publication in the International Financial Statistics (IFS).

Both the consumer and wholesale price indices are reported on a regular and timely basis for publication in the IFS. The consumer price index has a base period of March $1997=100$, and the wholesale price index's base has been updated to 2001. The coverage of the CPI is limited to the capital city.

\section{Government finances}

Official data on the central administration, the state enterprises and the social security system are complete and current, but there are problems with the timeliness of the data on local governments; there are also problems with the timeliness of financing and debt data reported for inclusion in the Fund's statistical publications. The multisector mission that visited Uruguay in November 1999 reviewed the sources used for the compilation of central government financing data and identified sources of information for local governments. The mission made recommendations for the compilation of this data and its reporting to STA. The information reported for publication in the Government Finance Statistics Yearbook includes data on the central government; however, complete annual central government debt 
data have not been reported for periods after 1994 and data on local governments have not been reported for periods after 1997.

\section{Monetary accounts}

Two STA money and banking statistics missions visited Montevideo in July 1998 and March 1999. The missions reviewed the timeliness, coverage, and classification of the monetary accounts for the banking system and developed a unified system for reporting data to the Fund. The 1999 multisector mission continued work on improving the basic source data and the methodology for compiling monetary statistics, and recommended a new reporting system, which has since been adopted by the Central Bank. The mission developed a database that contains the data needs for publication in IFS and for operational use by WHD.

The STA mission that visited Montevideo in April 2003 provided recommendations for the adequate recording of the loans funded from the Fund for the Stabilization of the Banking System (FSBS) in the Central Bank's balance sheet. The mission's recommendations have been implemented and were reflected in the IFS June 2003 issue.

\section{Balance of payments}

Balance of payments statements are compiled and published on a quarterly basis. Data are compiled following the recommendations of the fifth edition of the Balance of Payments Manual (BPM5). The authorities have made significant progress in implementing the multisector mission recommendations in order to improve the coverage and quality of balance of payments estimates. The directory of direct investment enterprises has been updated and measures have been introduced to improve the survey on inward investment; quarterly surveys have been introduced in the case of services, and other activities not currently covered; the coverage of reserve assets has been revised to exclude certain assets that are not available to finance balance of payments needs. Uruguay compiles and reports to STA annual data on balance of payments and the international investment position (IIP) for publication in the IFS and the Balance of Payments Statistics Yearbook. The new surveys would also allow for improved coverage of the private sector in the IIP.

In October 2003, Uruguay disseminated the international reserves and foreign currency liquidity data template on the Central Bank's website for the first time. Monthly information on the data template is currently available for August-November 2003. 
- 47 -

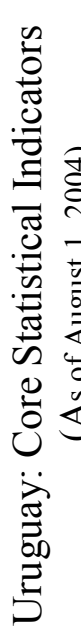

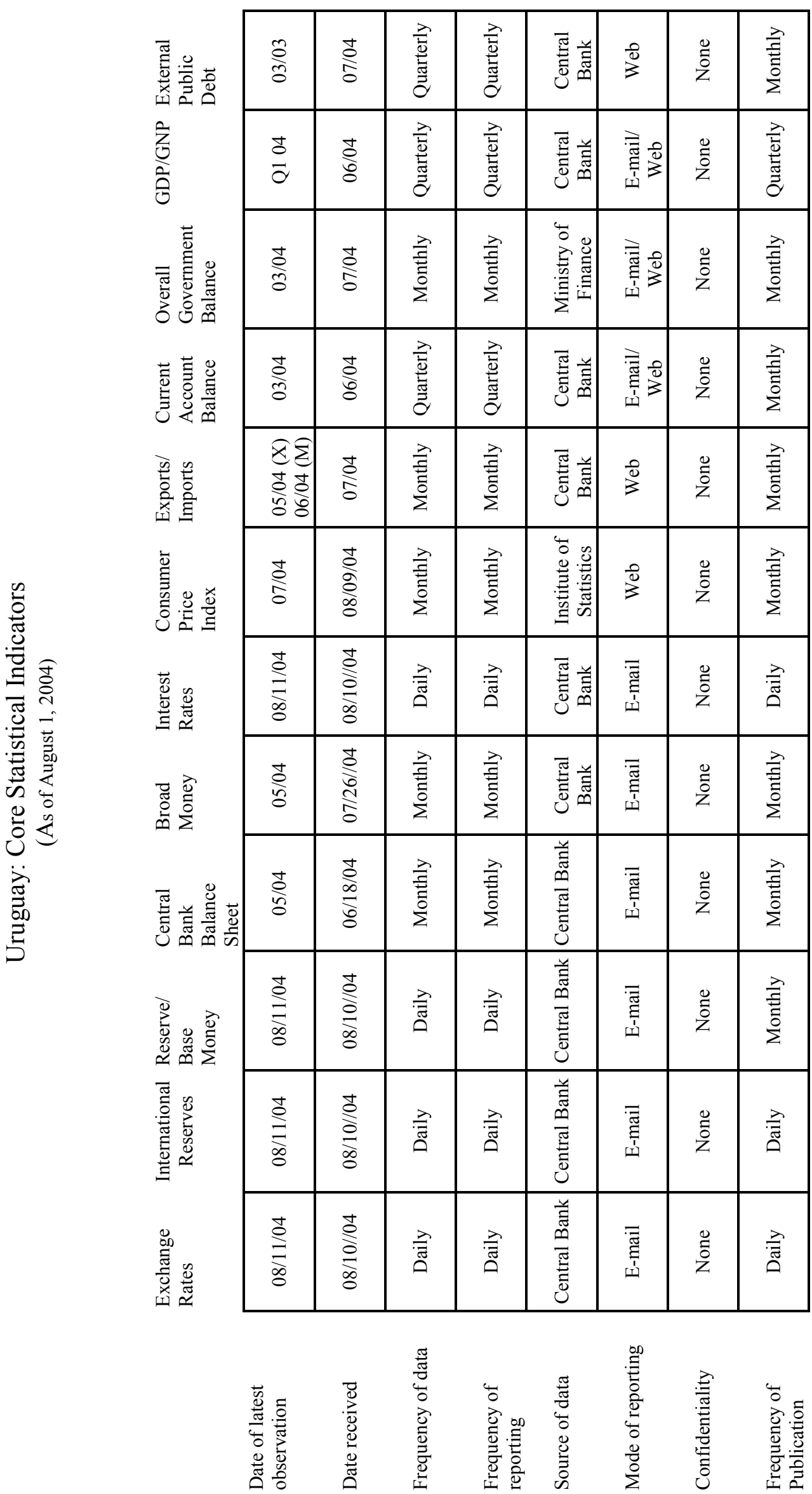




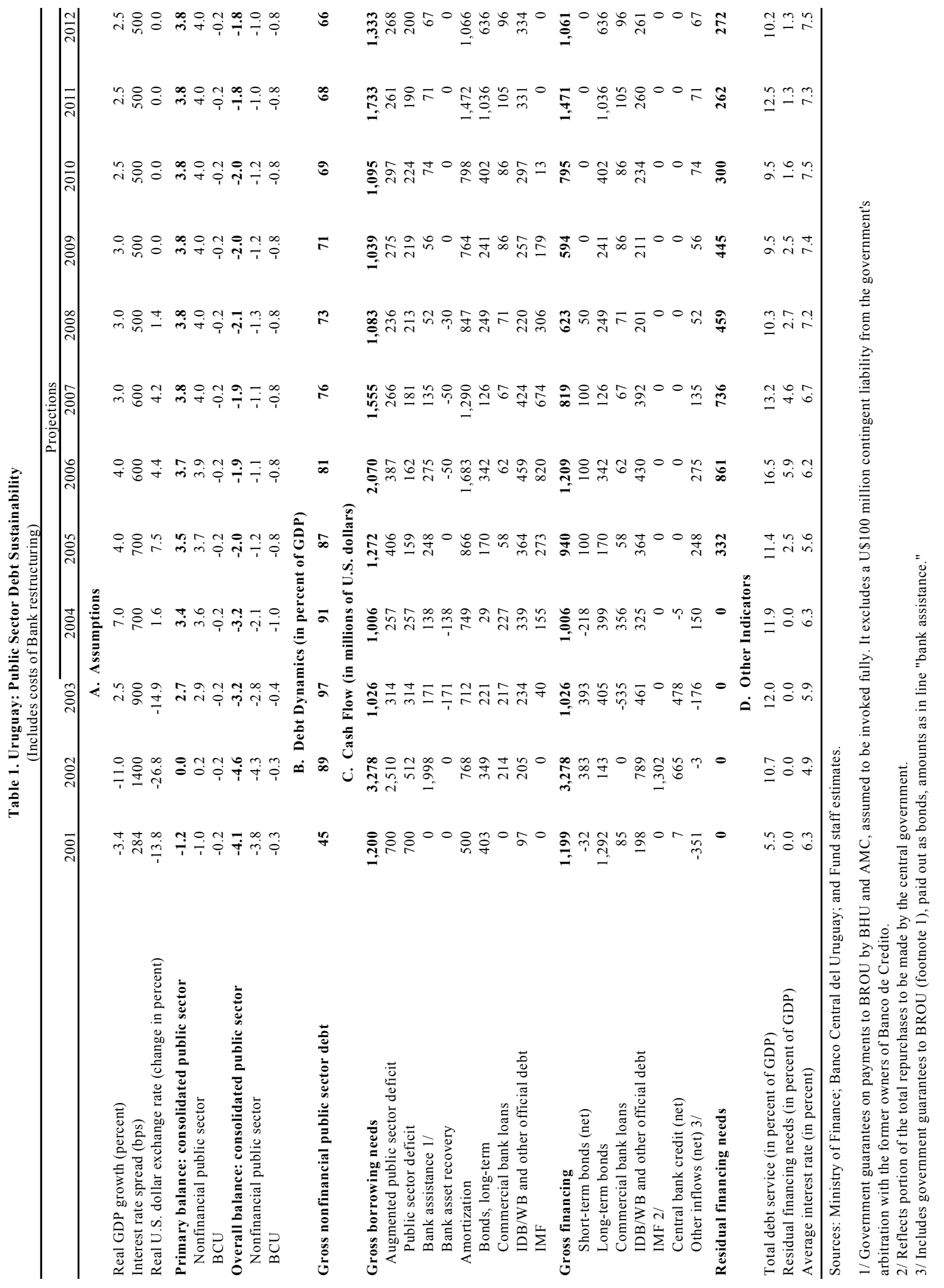




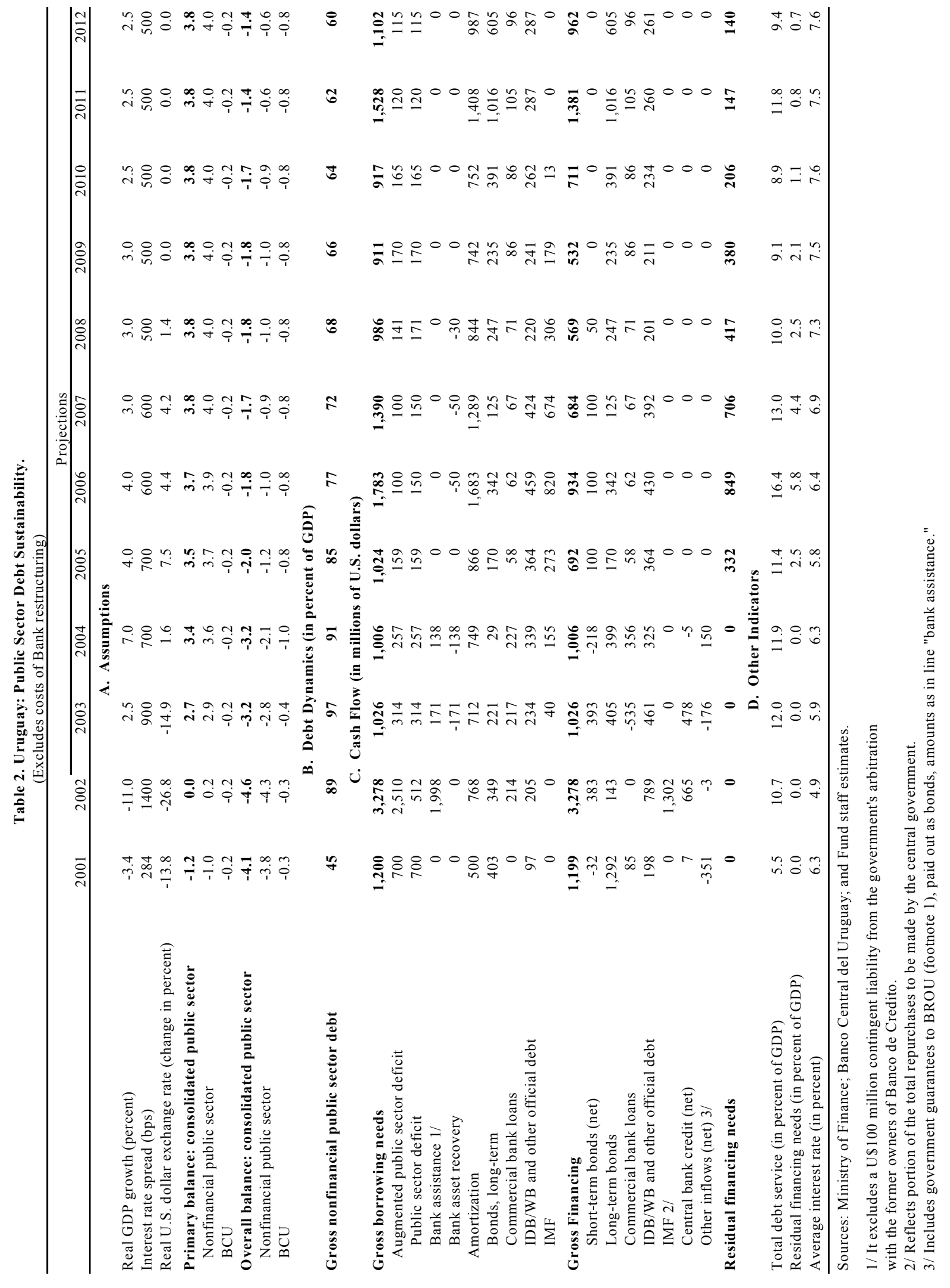




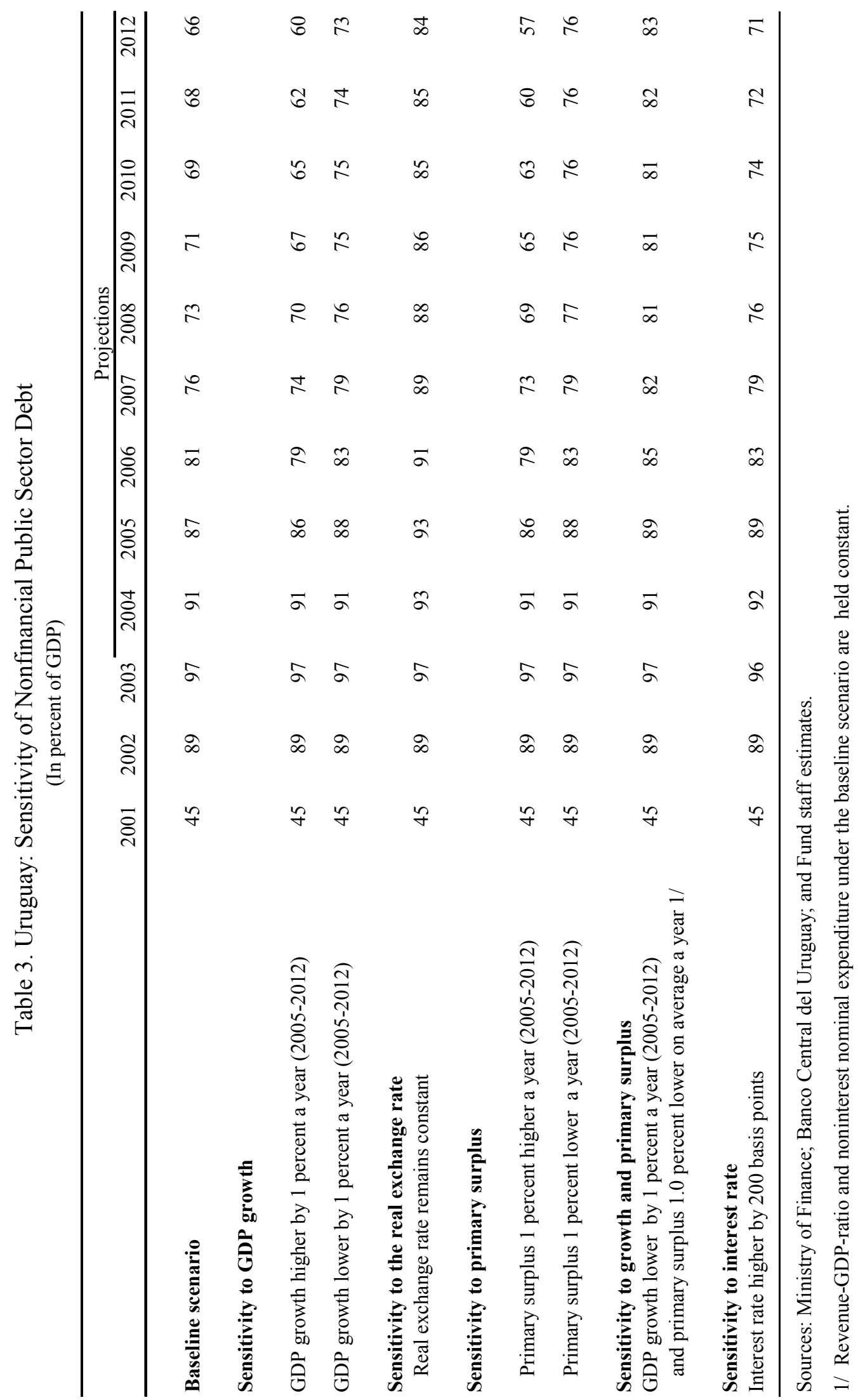




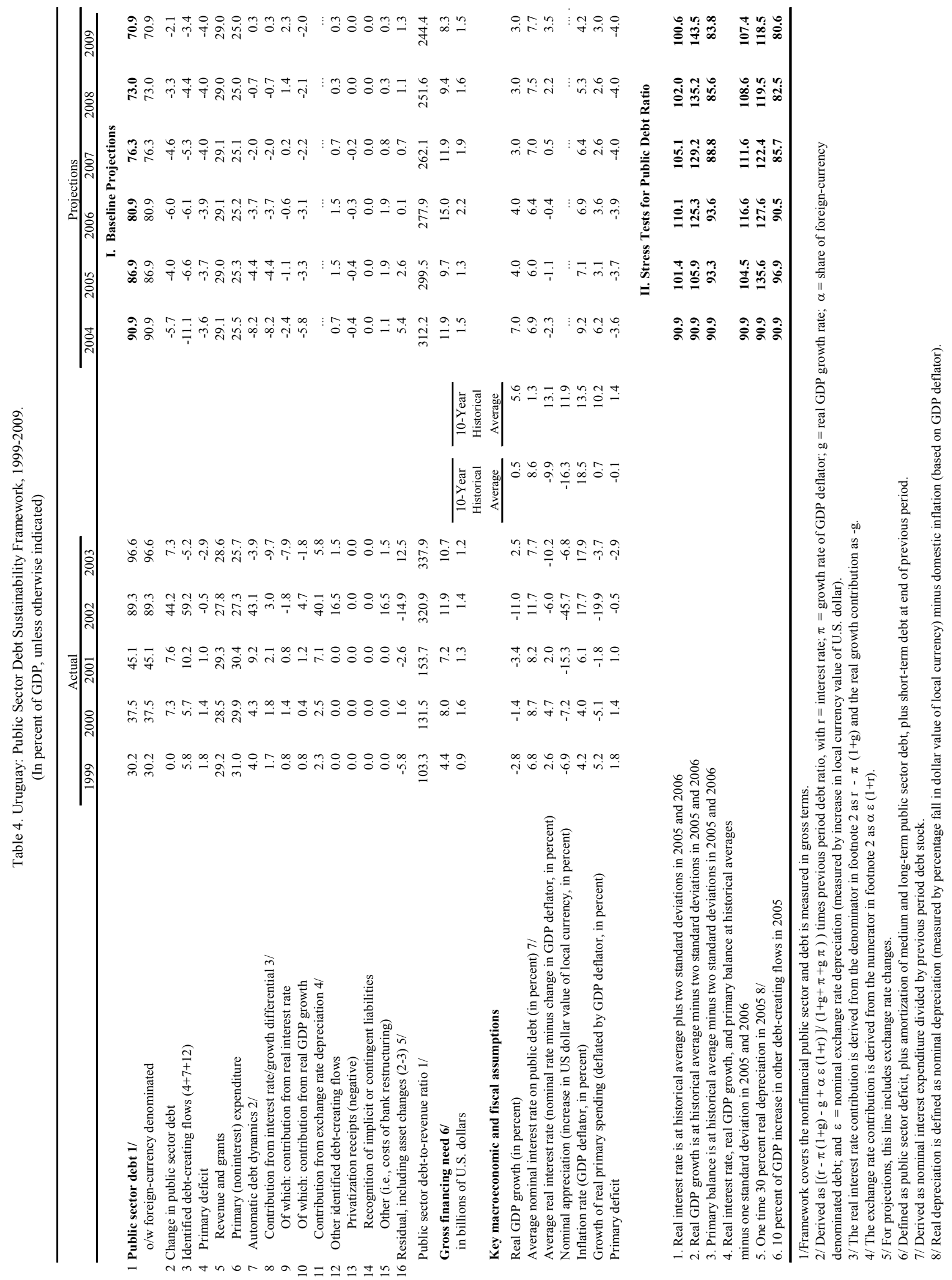




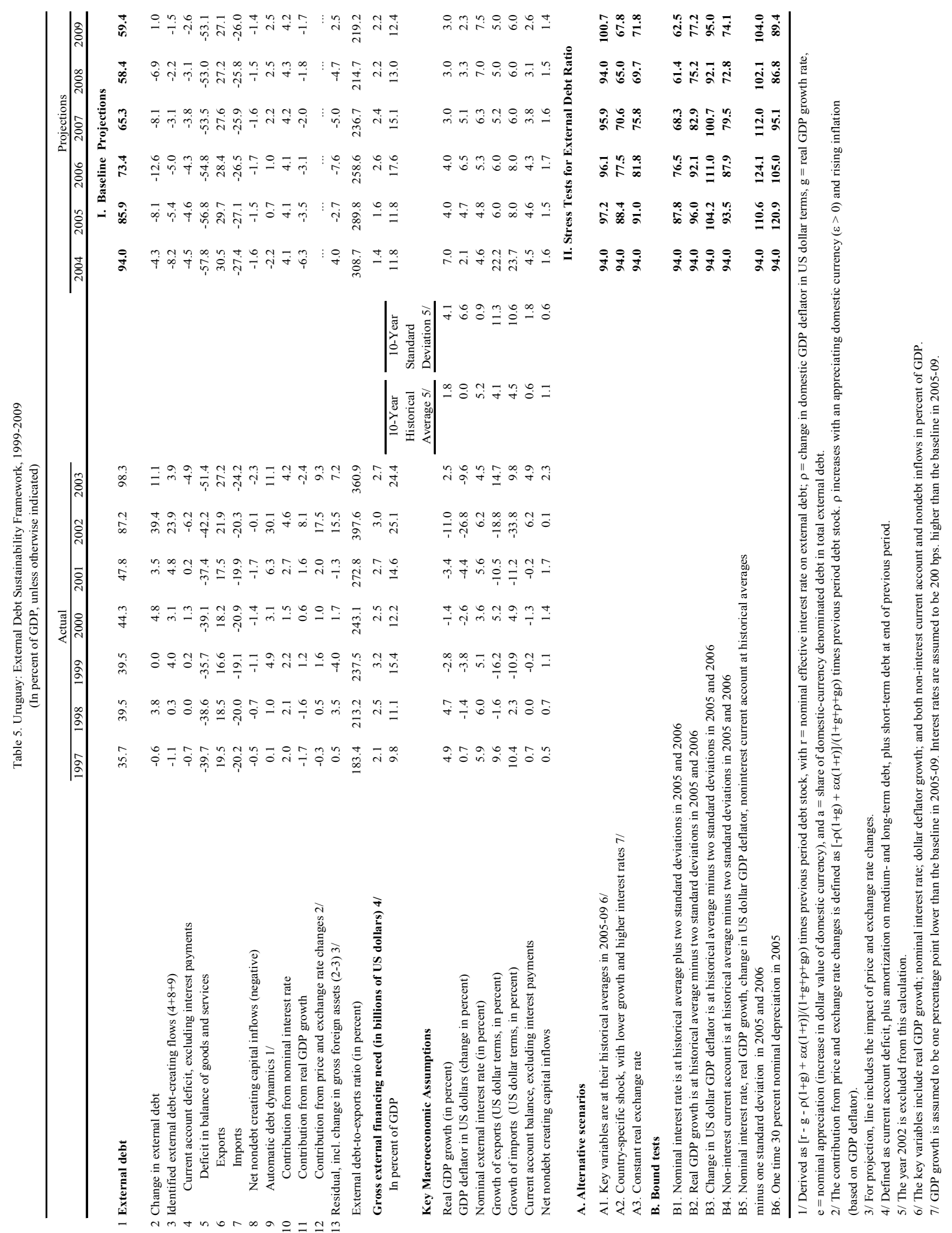


Montevideo, Uruguay

August 12, 2004

Dear Mr. de Rato:

Since the completion of the fourth review under the Stand-By Arrangement last February, the Uruguayan economy has staged an impressive recovery, and is expected to grow by at least 7 percent in 2004. Financial indicators have also continued to strengthen. Available data indicate that the quantitative performance criteria (PCs) under the program for end-June on NIR, NDA, and general government noninterest expenditure have been observed, as were the end-March PCs on the public sector primary surplus and the nonfinancial public sector gross debt. This performance reflects the macroeconomic and structural policies that the Uruguayan government has implemented since the onset of the financial crisis. The government remains firmly committed to consolidating the gains achieved so far and to completing the objectives of the program, through continued sound fiscal and monetary policies and the implementation of measures to strengthen further the financial system.

The attached Supplement to the Memorandum of Economic and Financial Policies updates the economic program of the government of Uruguay through the end of the Stand-By Arrangement in March 2005, and establishes end-September and end-December quantitative performance criteria and structural performance criteria within that period. The last purchase under the arrangement is subject to a program review to be completed by mid-February 2005 .

In support of its program, the government requests: (i) completion of the fifth review under the Stand-By Arrangement, with availability of a purchase equivalent to SDR 139.8 million; (ii) waivers of applicability of the end-June performance criteria on the combined public sector primary balance and the nonfinancial public sector gross debt, for which data would not be available by the time of the Board meeting; (iii) waivers of nonobservance of the end-March 2004 structural performance criteria on the outsourcing of assets of liquidated banks and the contracting of specialized asset recovery services for the fiduciary trust of the public bank BROU. The waivers of nonobservance of the two structural performance criteria are requested on the basis of the remedial measures that have been implemented and our commitment to maintain the policy framework established under the program. In particular, the structural performance criterion on BROU's contracting of specialized services was observed with only a slight delay.

We also request a rephasing of the remaining purchases under the arrangement (Table A), including a final review of the program to be held in February 2005. With the improvement of Uruguay's economic outlook and external position, we have decided to forgo the purchase originally envisaged for August and reduce the total remaining access by SDR 139.8 million.

The Government of Uruguay is confident that the policies set out in the attached Supplement will ensure the success of the program and justify the requested waivers and completion of the review. The continued support of the international financial institutions will be fundamental in sustaining the economic recovery and maintaining financial stability. The 
Government stands ready, in consultation with the Fund, to take additional measures necessary to ensure the success of the program.

Sincerely yours,
/S/
Julio de Brun
$/ \mathrm{s} /$
President
Central Bank of Uruguay
Isaac Alfie
Minister of Economy and Finance
Oriental Republic of Uruguay

Mr. Rodrigo de Rato

Managing Director

International Monetary Fund

700 19th Street NW

Washington DC

Attachments:

Supplement to the Memorandum of Economic and Financial Policies

Technical Memorandum of Understanding

Table A. Schedule of Remaining Purchases Under the Stand-By Arrangement (in millions of SDRs)

\begin{tabular}{lrrllll}
\hline Original schedule (Country Report 04/172) & \multicolumn{4}{c}{ Proposed revised schedule } \\
\cline { 1 - 3 } \cline { 7 - 8 } Date & SDR & \% quota & & Date & SDR & \% quota \\
\hline May 2004 & 139.8 & 45.6 & & & \\
August 2004 & 139.8 & 45.6 & & May 2004 & 139.8 & 45.6 \\
November 2004 & 139.8 & 45.6 & November 2004 & 139.8 & 45.6 \\
February 2005 & 139.8 & 45.6 & & February 2005 & 139.8 & 45.6 \\
\hline
\end{tabular}




\section{Supplement to The Memorandum of Economic and Financial Policies}

\section{BACKGROUND}

1. The economic recovery in 2003 has turned out stronger than previously envisaged, and leading indicators point to a further acceleration of growth in 2004: Real GDP grew 12 percent during the second half of 2003 and 14 percent in the first quarter of 2004. Financial indicators have also continued to improve. Inflation has declined to near single digits and bank deposits have increased. Gross international reserves have held firm in 2004, at US\$2 billion by end-July, which has helped to raise to about 60 percent the coverage of dollar liabilities in the banking system by official reserves and banks' foreign assets. All 2004 quantitative PCs under the program for which data are available have been observed.

2. Consistent with these developments, we have raised our projection for economic growth in 2004. The government expects that real GDP will grow by at least 7 percent, with inflation in the 7-9 percent range by year-end. The stronger-than-envisaged balance of payments position will allow us to raise the program target on net international reserve accumulation for 2004 from US\$100 million to US\$180 million. Over the medium term, we expect growth to average 3-4 percent, supported by sound macroeconomic policies and sustained implementation of structural reforms.

\section{Fiscal And Monetary Policies}

3. The government remains firmly committed to achieving the primary surplus targets under the program, to put Uruguay on a path of debt sustainability while providing room for supporting private sector growth. The fiscal program is well on track, allowing us room to roll back temporary tax surcharges on wages and corporate income and taxes on commissions and public utilities that were implemented during the economic crisis. Expenditure restraint will be maintained, keeping the growth in central government noninterest expenditure to 9 percent and the wage bill of the central government to Ur $\$ 15 \frac{1}{2}$ billion, as envisaged under the program; and tariffs charged by public enterprises will continue to be adjusted in line with operating costs. Revenue higher than envisaged under the program will not be used to increase expenditure, and no further tax reductions will be implemented. In light of the strong fiscal performance in the first half of the year, we have raised our end-year primary surplus target to 3.4 percent of GDP (up from the original target of 3.2 percent of GDP). We will also closely monitor the floating debt of the nonfinancial public sector, to ensure that it does not rise during the program period.

4. The government remains committed to improving the efficiency of the tax system. Steady progress is being made in modernizing the Tax Administration Department (DGI). The DGI is upgrading its physical facilities and is improving its computer system and taxpayer-audit procedures. The DGI has also initiated the establishment of an internal audit unit, and is coordinating with the real estate registry to improve taxpayer compliance. However, we now expect the establishment of the Large Taxpayers Unit (an end-September structural benchmark) to be completed by December (structural benchmark). Also, prospects 
for legislative approval of the tax reform package submitted in June 2003 are unlikely; nevertheless, we will continue to foster dialogue and seek consensus toward adoption of this reform. In this context, the government will not grant any new tax exemptions and will work to phase out existing ones.

5. Over the medium term, Uruguay needs to attain primary surpluses rising to about 4 percent of GDP to put the country on a path toward debt sustainability and to avoid crowding out credit to the private sector. Under this path, the debt-to-GDP ratio is projected to decline to between 60-70 percent by 2012, consistent with the objectives of the May 2003 debt exchange. For 2005, we are committed to an expenditure plan that, under the current tax structure, is consistent with a primary surplus of $3 \frac{1}{2}$ percent of GDP as envisaged in the medium-term framework under the program.

6. The Central Bank of Uruguay (BCU) will continue the policy of a floating exchange rate, with base money as the intermediate target of monetary policy. To impart greater flexibility into monetary policy operations, the BCU has established a repurchase (repo) mechanism to address intramonthly variability in the demand for pesos. In March, to improve the transparency of exchange market operations, the BCU began announcing foreign exchange purchase plans for one month ahead. For 2004, base money is targeted to grow by 9 percent, consistent with the revised macroeconomic framework. To the extent that market conditions permit, we intend to (i) reduce the stock of costly BCU debt to improve the quasifiscal position of the central bank, (ii) promote the use of peso instruments, and (iii) attain a modest buildup of net international reserves.

\section{RESTRUCTURING OF THE BANKING SYSTEM}

7. The government will continue to strengthen further the banking system and will accelerate the disposal of assets in the liquidated banks, in close consultation with the Fund. Progress is being made in implementing our comprehensive restructuring of the public financial institutions BROU and $\mathrm{BHU}$, and we are moving ahead on soliciting equity investment in the new commercial bank NBC, in which the government holds 100 percent of the shares.

8. Accelerating the disposal of the remaining assets of the liquidation funds will be a key priority during the remainder of the program. Following the delays that have hampered the process over the past year, we have taken measures to ensure that the strategy will be in full operation before the end of the year. We have put in place the following steps:

- $\quad$ An inventory of the assets held by the funds is being completed and their balance sheets as of end-May have been prepared. To promote creditor discipline, information on nonperforming loans obtained from the inventory has been transferred to the Bank Superintendency for inclusion in the credit registry.

- $\quad$ Audit firms have been contracted to prepare: (i) financial statements for the funds' operations since inception; and (ii) financial audits of the funds. 
- A full-time supervisor has been appointed to oversee the implementation of the strategy.

- A contract will be signed with the firm selected through competitive bidding to manage all available assets of the liquidation funds, on the basis of a first tranche of at least US\$300 million.

- $\quad$ The liquidation funds will transmit to the Ministry of Economy and Finance (MEF) and BCU their July financial statements.

9. Consistent with our fiduciary responsibility, we will closely oversee the activity and performance of the asset manager and the bank liquidation funds, including through establishing structural benchmarks under the program for future reviews on the performance of the asset manager, in line with its business plan. We will take the following additional measures:

- $\quad$ The financial statements since the inception of the liquidation funds will be completed by end-September; and the financial audits, by end-October (structural performance criteria).

- $\quad$ All the remaining available assets will be transferred to the asset manager by end-October (structural performance criterion).

- The liquidation funds will continue transmitting monthly financial statements (by the 20th of the following month) to the Ministry of Economy and Finance (MEF) and BCU (monthly structural performance criterion beginning in September).

- $\quad$ The funds will also publish quarterly financial reports within 30 days of the close of the quarter (end-January 2005 structural performance criterion).

10. BROU is making progress toward achieving its financial targets for end-2004. BROU's business plan is proceeding on schedule and progress will continue to be monitored under program reviews.

- The end-March and end-June structural performance criteria on transferring to the fiduciary trust the second and third tranches of BROU's nonperforming loans have been observed. BROU's Executive Board will take the legal steps to ensure the smooth transfer of all new and remaining nonperforming loans by end-December (structural performance criterion). An audit firm is about to complete the audit to reassess the value of all assets in the fiduciary trust (an end-June structural benchmark).

- $\quad$ The general manager of the fiduciary trust has contracted specialized asset recovery services (an end-March structural performance criterion), including collection 
agencies and legal services, albeit with some delays. The trust started operating in April.

- $\quad$ BROU's operational restructuring is proceeding as planned, and the bank's operating costs will be reduced by 15 percent during 2004-05. In line with the business plan, operations are being rationalized, credit risk management is being improved, and activity is being redirected toward business segments where BROU has a competitive advantage.

- $\quad$ The release of the second tranche of reprogrammed deposits has been completed, and results have been positive, with about 95 percent of deposits remaining in BROU. BROU is continuing to build up liquidity in order to meet the repayment of the third tranche of reprogrammed deposits, which is scheduled for next year.

11. The restructuring of BHU is moving forward. BHU has observed World Bank conditionality on its operational restructuring, enabling the disbursement of US\$50 million under the World Bank's SAL-I operation in the third quarter. BHU's government-guaranteed obligation to BROU is being serviced, and its operations are being closely monitored to ensure the timely service of the note (a continuous structural performance criterion).

12. As part of strengthening NBC, improvements to NBC's governance are envisaged, in line with the recommendations of the Banking Superintendency, including increasing the size of its Executive Board and appointing to the Board individuals experienced in commercial banking. We will continue to pursue negotiations with the IFC for a strategic equity stake in NBC.

13. Some progress has been made in winding down the liquidation of Banco de Crédito. An attempt to auction its liquidation fund's remaining nonperforming loans did not prosper because of a lack of acceptable offers. In light of this situation, we have begun the process of extinguishing all remaining depositor claims through the purchase of some of the liquidation fund's assets with government bonds (face value) that have been held in the government's portfolio. We intend to dispose of these assets as well as all remaining assets in the liquidation fund of Banco de Crédito by end-December, including through the securitization of performing loans and the appointment of a manager to work out nonperforming loans. The recoveries from these operations will fully accrue to the government, which holds all remaining claims against Banco de Crédito's liquidation fund.

14. The government will not increase its compensation plan for depositors and other creditors of the other three liquidated banks beyond the recent exchange offer (on market terms) to bondholders and depositors with claims in excess of US $\$ 100,000$ for a swap of these claims and shorter-term government bonds for longer-term government bonds that does not involve any net resource transfer from the government. The Fund for the Stability of the Banking System (FSBS), having fulfilled its original purpose of providing backing for sight and savings deposits at qualifying banks, has been closed, and the remaining balance was used for an early repurchase to the Fund. 
15. The government is pursuing measures to improve bank supervision. Most important, banks are being required to improve their risk management procedures. With assistance from the IDB under the Financial Sector Loan, the capacity of the Banking Superintendency is being bolstered, including through the hiring of additional staff and strengthening of on-site supervision.

\section{Structural Reforms, Data Provision, and Safeguards Measures}

16. In addition to maintaining sound financial policies, structural reforms will be critical in promoting medium-term growth prospects. These reforms include reducing the involvement of the public sector in the economy and improving its efficiency, gradually opening the areas where public enterprises operate to private sector competition, and further improving the institutional framework and investment climate.

17. The government will continue efforts to encourage investment and private sector activity and deepen Uruguay's integration into the global economy. Toward these ends, we are pursuing the following measures:

- International trade and investment are being promoted. The free trade agreement with Mexico is being implemented, and the auction of the cellular phone concession in May was successful. A bilateral investment treaty with Finland was ratified in May, and we hope to conclude the negotiations on a similar treaty with the United States by August.

- A law that regulates the issuance of warrants has been approved and-in conjunction with the trust fund law-will facilitate the development of a broader range of financing instruments for the private sector.

- Legislation has been approved that clarifies the legal status of the inflation indexation unit to help foster the development of the market for peso-denominated instruments.

- We will continue to work toward legislative approval of structural reform measures supported by multilateral disbursements, including in the areas of the regulatory frameworks for the gas and water sectors. The government has also received a grant from the World Bank to promote energy efficiency.

- We will continue to pursue the adoption of reforms of the specialized pension funds for the police, the military, and bank employees (end-December structural benchmarks).

18. To improve the provision of fiscal data for program monitoring purposes, we have established a committee to bolster coordination between the MEF, the BCU, BROU, and $\mathrm{BHU}$, with the objective of providing the necessary fiscal information for monitoring targets under the program within 60 days of the close of the previous quarter and, thus, avoid the 
need for waivers of applicability for test dates more than two months past. We are allocating more resources for data collection and analysis, and will continue to provide timely data under the SDDS.

19. We are continuing to carry out the recommendations of the on-site Safeguards Assessment completed by the Fund in 2002. A supplementary external audit of the FSBS is underway and an external audit of the 2003 accounts of the BCU has been completed.

\section{Financing Assurances}

20. The successful international bond issue in late July completes our financing needs through March 2005, and residual financing needs for the next few years have been largely addressed by the debt exchange in May 2003. Stronger efforts to implement structural reforms will help ensure the flow of IFI disbursements, projected at about US\$300 million through end-2004, broadly in line with amortization payments to these institutions. 


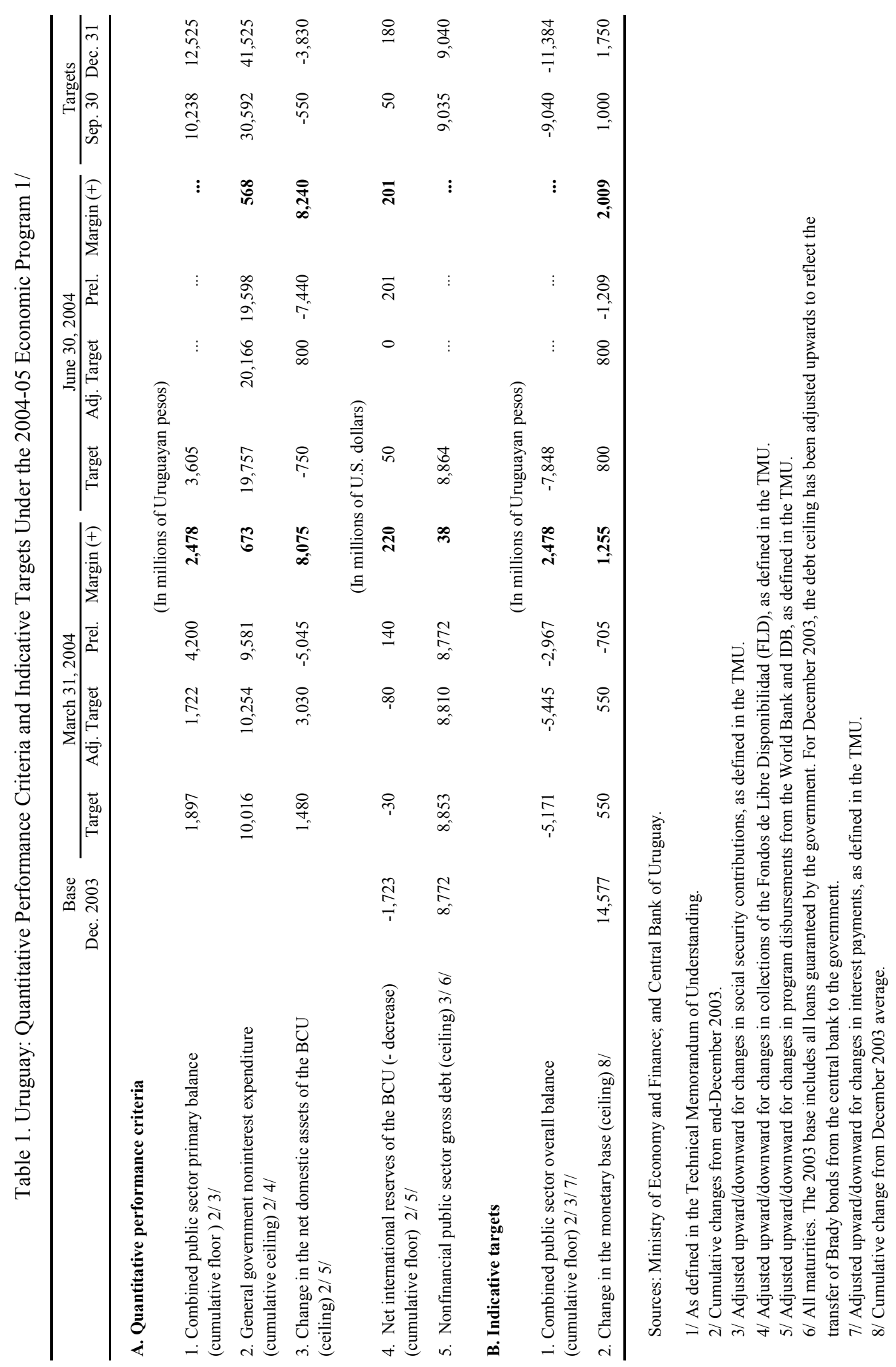


Table 2. Uruguay: Structural Conditionality Under the 2004-05 Economic Program 1/

Structural conditionality

Expected timing

\section{A. Prior actions}

Completion of the inventory of assets held by the liquidation funds.

Transfer to the Banking Superintendency of information on nonperforming borrowers whose loans are held by the liquidation funds, for inclusion in the credit registry.

Preparation of balance sheets, as of end-May, for each of the liquidation funds.

Appointment by BCU of full-time supervisor to oversee the activities of the liquidation funds.

Contract an accounting firm to prepare financial statements covering operations of the liquidation funds since inception.

Contract an audit firm to perform financial audits of the liquidation funds.

Contract a firm to manage all available assets of the liquidation funds, and assign management of at least US\$300 million as a first tranche.

Submission of the end-July financial statements of the liquidation funds to the MEF and the BCU.

Formation of a fiscal monitoring committee comprising representatives from MEF, BCU, $\mathrm{BROU}$, and $\mathrm{BHU}$ to ensure provision of fiscal data necessary for monitoring performance under the program within 60 days of the close of the preceding quarter, as provided in the TMU.

\section{B. Structural performance criteria}

Completion of financial statements covering the operations of the liquidation funds since inception.

Completion of external financial audit of the liquidation funds.

Completion of transfer of remaining available assets of the liquidation funds to the asset

October 31,2004 manager.

October 31, 2004

Completion of the transfer to the BROU fiduciary trust of all new and remaining Category 4

December 31, 2004 and 5 loans.

Publication of quarterly financial reports of the liquidation funds for end-December 2004.

January 31,2005

Submission of monthly financial statements of the liquidation funds by the 20th of the following month to the MEF and the BCU, starting with the end-August statement.

Monthly, beginning September 20, 2004

Government to ensure timely service of BHU note to BROU.

Continuous

\section{B. Structural benchmarks}

Establishment of a Large Taxpayers Unit at the Tax Administration Department (DGI).

December 31, 2004

Approval by Congress of the reform of the pension funds for the police and the military.

December 31, 2004

Approval by Congress of the reform of the pension funds for bank employees.

December 31, 2004

1/ As defined in the Technical Memorandum of Understanding. 


\section{TeChNiCAL MEMORANDUM OF Understanding}

This memorandum presents the definitions of the variables included in the performance criteria and benchmarks annexed to the Memorandum of Economic and Financial Policies.

1. Cumulative primary balance of the combined public sector. The combined public sector comprises the central administration (including as defined in "Article 220" of the Constitution, Salto Grande, and the funds managed directly in the ministries (Fondos de Libre Disponibilidad), the social security system (Banco de Previsión Social, Caja Militar, and Caja Policial), the local governments (Intendencias), the public enterprises (ANCAP, ANTEL, UTE, OSE, AFE, ANP, INC, and ANCO), and the quasifiscal balance of the Central Bank (BCU). The public sector primary balance, excluding valuation adjustments, will be calculated as the overall balance measured from below the line minus interest payments measured from above the line.

- The below the line overall balance will be measured on the basis of information provided by the BCU on: (i) the change in the nonfinancial public sector debt (defined below), including all short term debt, in foreign currency and pesos; (ii) change in net bank credit to the nonfinancial public sector in foreign currency and pesos; (iii) other nonbank financing including privatization; and (iv) the quasi-fiscal balance of the BCU (defined below). All upfront payments relating to future concessions, including the sale of mobile phone licenses, will be treated below the line.

- $\quad$ The floor on the primary balance of the combined public sector will be adjusted downward (upward) by the amount by which the actual social security contributions transferred to the private pension system exceeds (falls short of) the projected amounts in the program, specified in Schedule A.

\begin{tabular}{|lrrrr|}
\hline \multicolumn{7}{|c|}{ Schedule A } \\
(In millions of Uruguayan pesos, cumulative basis) & & \\
\hline & Mar-04 & Jun-04 & Sep-04 & Dec-04 \\
\hline Projected social security contributions & 824 & 1,573 & 2,641 & 3,417 \\
\hline
\end{tabular}

2. Cumulative balance of the combined public sector (indicative target). The combined public sector balance is calculated as the sum of the primary balance of the combined public sector described in 1 and interest payments. Interest payments are defined to exclude commissions and fees. The floor on the balance of the combined public sector will be adjusted downward (upward) by the amount that the interest payments exceed (fall short of) the projected amounts in the program, specified in Schedule B. 
Schedule B

(In millions of Uruguayan pesos, cumulative basis)

\begin{tabular}{lrrrr}
\hline & Mar-04 & Jun-04 & Sep-04 & Dec-04 \\
\hline Projected interest payments & 7,068 & 11,454 & 19,278 & 23,909 \\
\hline
\end{tabular}

3. The quasi-fiscal balance of the $\mathbf{B C U}$ is defined as interest earnings on gross international reserves, as defined below, and other earnings including those on other foreign and domestic assets minus operating expenses, commissions paid, and interest paid on domestic and foreign debt administered by the BCU.

4. Cumulative ceiling on general government expenditure applies to total (current and capital) noninterest expenditure of the central administration (includes Fondos de Libre Disponibilidad but excludes transfers to the social security system, automatic transfers to the private pension funds (AFAPs), and earmarked revenue) and the social security system (BPS). The ceiling on general government expenditure will be adjusted downward for any expenses arising from pension adjustments which exceed the increase in the legal minimum adjustment. The ceiling on general government expenditure will be adjusted upward (downward) by the amount by which the actual revenues from the Fondos de Libre Disponibildad (FLD) exceeds (falls short of) the projected amounts in the program, specified in Schedule C.

\begin{tabular}{|lrrrr|}
\hline \multicolumn{6}{c|}{ Schedule C } \\
(In millions of Uruguayan pesos, cumulative basis) & & \\
\hline & Mar-04 & Jun-04 & Sep-04 & Dec-04 \\
\hline \multirow{2}{*}{ Projected revenues from the FLD } & $\ldots$ & $\ldots$ & 3,910 & 5,258 \\
\hline
\end{tabular}

5. Cumulative changes in net domestic assets (NDA) of the BCU is defined as the difference between end-of-period monetary base and net international reserves (NIR) of the BCU as defined in paragraphs 6 and 7 below. The flow of NIR will be valued at the accounting exchange rate of Ur\$31 pesos per US\$1. The limit on the change in the NDA will be adjusted by the difference between actual program loan disbursements by the World Bank and IDB and scheduled loan disbursements as reflected in Schedule D:

- $\quad$ The NDA ceiling at end-March, end-June, end-September, and end-December will be adjusted upward in the event of shortfalls compared with projected program loan disbursements, up to a limit of US\$50 million.

- $\quad$ The NDA ceiling will be adjusted downward in the event of excesses over projected program loan disbursements by their full amount. 
Schedule D

(In millions of U.S. dollars, cumulative basis)

\begin{tabular}{lrrrr}
\hline & Mar-04 & Jun-04 & Sep-04 & Dec-04 \\
\hline Total program disbursements & 110 & 110 & 160 & 166 \\
World Bank & 50 & 50 & 100 & 100 \\
IDB & 60 & 60 & 60 & 66 \\
$\quad$ of which: multisectoral loan & 0 & 0 & 0 & 6 \\
\hline
\end{tabular}

6. Monetary base (indicative target) is defined as the sum of (i) currency issue; (ii) nonremunerated and remunerated peso sight deposits of BROU, BHU, private banks, and other institutions defined below at the BCU; and (iii) call deposits of BROU, BHU, private banks, and other institutions at the BCU. Other institutions include pension funds (AFAPs), local governments, public enterprises, trust funds of the liquidated banks (FRPB), investment funds, offshore institutions (IFEs), insurance companies, exchange houses, stock brokers, and the nonfinancial private sector. The monetary base excludes central government deposits held at BROU subject to a 100 percent reserve requirement. The indicative target is defined as the cumulative change calculated using the monthly averages relative to the base month average.

\section{Cumulative changes in net international reserves (NIR) of the BCU. NIR is}

defined as the difference between the gross international reserves and BCU reserve liabilities. Gross international reserves include all foreign exchange assets that are in the direct effective control of the BCU and are readily available for such purposes of the BCU as intervention or direct financing of payment imbalances. Such assets may be in any of the following forms, provided that they meet the test of effective control and ready availability for use: currency, bank deposits in nonresident institutions and government securities and other bonds and notes issued by nonresidents (with a rating not below " $A$ " in the classification of Fitch and IBCA and Standard and Poor's or "A2" in the classification of Moody's). In addition, holdings of SDRs or of monetary gold would be included under gross international reserves (provided they meet the test of effective control and ready availability of use) as would the reserve position in the IMF.

- $\quad$ Excluded from gross international reserves are all foreign currency claims arising from off-balance sheet transactions (such as derivatives instruments), claims on residents, capital subscriptions to international financial institutions, any assets in nonconvertible currencies, claims on any nonresident Uruguay-owned institutions, or any amounts (in all components of assets, including gold) that have been pledged in a direct or contingent way. Also excluded are certificates of deposit used to constitute reserve requirements at the BCU.

- $\quad$ Also excluded from gross international reserves are foreign exchange assets in the escrow account at the BCU created to provide backing to sight and savings deposits at the 
public banks and the closed domestic banks (the escrow account at the BCU). Funds not used to support banks will be invested in highly liquid and secure international assets to be reported daily to the IMF and will be subject to periodic special audits.

- $\quad$ BCU reserve liabilities include all foreign currency-denominated liabilities of the BCU with original maturity of one year or less to residents and nonresidents, all certificates of deposit used to constitute reserve requirements against bank deposits, the use of Fund resources, any net position on foreign exchange derivatives with either residents or nonresidents undertaken directly by the $\mathrm{BCU}$ or by other financial institutions on behalf of the BCU.

- $\quad$ For the purpose of the NIR calculation, (i) the gold holdings of the BCU will be valued at the accounting rate of US\$42 per troy ounce; (ii) liabilities to the IMF will be valued at the rate of US\$1.395 per SDR; (iii) gains or losses from gold swaps and other operations will be excluded; and (iv) non-U.S. dollar denominated foreign assets and liabilities will be converted into U.S. dollars at the market exchange rates of the respective currencies as of December 31, 2003.

8. The NIR floor will be adjusted by the difference between actual program loan disbursements by the World Bank and IDB, and scheduled loan disbursements by the World Bank and IDB as reflected in Schedule D, in the following manner:

- $\quad$ The NIR floor at end-March, end-June, end-September, and end-December will be adjusted downward in the event of shortfalls compared with projected program loan disbursements, up to a limit of US\$50 million.

- $\quad$ The NIR floor will be adjusted upward in the event of excesses over projected program loan disbursements by their full amount.

9. The nonfinancial public sector gross debt refers to the outstanding stock of gross debt in domestic and foreign currency owed or guaranteed by the nonfinancial public sector, excluding the BCU. ${ }^{1}$ Debt in the form of leases will be calculated as the present value (at the inception of the lease) of all lease payments expected to be made during the period of the agreement excluding those payments that cover the operation, repair or maintenance of the property. $^{2}$ The nonfinancial public sector debt ceiling will exclude the government

\footnotetext{
${ }^{1}$ The term "debt" has the meaning set forth in point No. 9 of the Fund's Guidelines on Performance Criteria with Respect to Foreign Debt (Decision No. 6230-(79/140, August 3, 1979), as amended).

2 The suppliers' contracts of ANTEL with equipment providers Ericsson and NEC, which predate the Fund's consideration of lease contracts for programming purposes, are expensed
} 
guaranteed BHU note (estimated at US\$610 million at end-December 2003) and the government guarantee covering notes issued by the fiduciary trust associated with the transfer of BROU's NPLs (estimated at US\$370 million at end-December 2003). It will include debt issued by the Megaconcesion that has a guarantee of the government.

\section{The overall nonfinancial public sector debt ceiling will be adjusted upward}

(downward) by (i) the upward (downward) revisions made to the actual nonfinancial public sector gross debt stock at end-2003; (ii) the difference between the actual and projected amount of social security contributions that are transferred to private pension funds according to Schedule A, i.e., the debt ceiling will be adjusted upward (downward) by the amount that social security contributions exceed (fall short of) those specified in Schedule A; (iii) the difference between the actual and projected interest payments, specified in Schedule B for end-March, end-June, and end-September, and end-December, i.e. the debt ceiling would be adjusted upward (downward) by the amount that interest payments exceed (fall short of) those specified in Schedule B; (iv) the difference between actual and scheduled program disbursements by the World Bank and IDB as reflected in schedule $\mathrm{C}$ above, i.e. the debt ceiling will be adjusted upward (downward) by the amount that program loan disbursements exceed (fall short of) those in Schedule $\mathrm{C}$, and any downward adjustment will be limited to US\$50 million; (v) the amount of the government guarantee on the BHU note that is called in 2004, excluding the clearance of existing arrears of BHU to BROU, i.e., the debt ceiling will be adjusted upward by the amount of new debt issued by the government to cover its guarantee (principal plus interest) on the BHU note; and (vi) the amount of the government guarantee on the transfer of BROU's NPLs to the fiduciary trust that is called in 2004, i.e., the debt ceiling will be adjusted upward by the amount of new debt issued by the government to cover its guarantee on the schedule of principal and interest payments owed by the trust to BROU; and (vii) the debt ceiling will be adjusted upward to reflect overperformance with respect to the targets on the BCU's net international reserves up to a limit of US\$250 million.

11. The data for assessing observance of the quantitative performance criterion on net international reserves will be provided by the BCU no later than one week after each test date. The data for the assessment of all other quantitative performance criteria and indicative targets will be provided by the BCU no later than two months after each test date.

12. Data, reports, and other relevant information for assessing progress on bank restructuring will be provided to staff in a timely manner; in particular, financial audits and associated management letters will be shared with the Fund.

under goods and services as rental outlays and, therefore, excluded from the definition of nonfinancial public sector gross debt for program purposes. 
13. The structural performance criteria for the transfer of BROU's Category 4 and 5 loans (end-June and end-December 2004 performance criteria) are defined to mean the transfer of nonperforming Category 4 and 5 loans.

14. The prior action and structural performance criterion (end-September 2004) on the outsourcing of the management of all available assets of the liquidation funds define available assets to include credits and collateral not in litigation and with which the asset management company does not have a conflict of interest arising from related parties and current and prior business relationships. The value of available assets is defined as outstanding principle and accrued interest for credits and the book value for other assets. 
INTERNATIONAL MONETARY FUND

URUGUAY

\title{
Fifth Review Under the Stand-By Arrangement and Requests for Modification of the Arrangement and Waiver of Nonobservance and Applicability of Performance Criteria
}

\author{
Supplementary Information \\ Prepared by the Western Hemisphere Department \\ (In collaboration with other Departments) \\ Approved by Markus Rodlauer and Martin Fetherston
}

August 25, 2004

1. Since issuance of the staff report for the Fifth Review, additional information on recent developments and policy measures has become available. This information does not alter the thrust of the staff appraisal.

2. Prior actions. All prior actions for completing the fifth review have been implemented (completion dates in parentheses):

- Inventories of assets for each of the liquidation funds have been prepared (August 10).

- $\quad$ The information on nonperforming loans obtained from the inventory has been submitted to the Bank Superintendency for inclusion in the credit registry (August 10).

- $\quad$ Balance sheets, as of end-May 2004, have been prepared for each of the liquidation funds (August 9).

- A full-time supervisor to oversee the implementation of the asset disposal strategy has been appointed (August 10).

- An accounting firm has been hired for the preparation of financial statements for the funds' operations since inception (July 25).

- $\quad$ An audit firm has been contracted to carry out financial audits of the liquidation funds (July 25). 
- A firm has been contracted, through a competitive bidding process, to manage the assets in the liquidation funds of Banco Comercial, Banco Montevideo, and Banco Caja Obrera, and a first tranche of NPLs of at least US\$300 million has been transferred to the asset management firm. While the prior action was completed only three days - rather than the customary five days - before the Board meeting (the contract with the asset management firm was signed on August 24), staff has been closely monitoring the bidding and contracting process, ${ }^{1}$ and can therefore assess with confidence that the prior action has been completed.

- $\quad$ The liquidation funds' end-July financial statements have been transmitted to the Ministry of Economy and Finance (MEF) and BCU (August 20).

- A fiscal monitoring committee, comprising representatives from the MEF, BCU, BROU, and BHU, has been formed (May 26).

3. Safeguards assessment. Further progress has been made toward completing the recommendations of the safeguards assessment. A supplementary audit on the use of FSBS reosurces by Banco de Crédito has been completed (the audits on the use of FSBS resources for Banco Comercial, Banco Montevideo, and Banco Caja Obrera are still ongoing).

4. Bank resolution process. A proposal was recently presented in congress that would create a large publicly-run asset management company (AMC) to take over the resolution of the distressed assets of liquidated banks and BROU, which would deviate substantially from the bank resolution strategy in the program. Although the proposal seemed initially to gather significant support in congress, its progress has recently slowed (it remains under discussion in the Finance Commission of the Senate). The authorities are confident that the proposal will not prosper in its current form, and have explained to staff that they would veto any legislation that substantially deviates from the current asset resolution strategy (which is based on the outsourcing of asset management for the liquidated banks and an asset resolution trust for BROU).

\footnotetext{
${ }^{1}$ The call for bids was done on July 20, and the winner was selected on August 10. The contract contains strong performance incentives for the asset manager, and the authorities have committed to monitor the collection effort closely and set performance measures in the context of future program reviews.
} 


\section{IMF Completes Fifth Review of Uruguay's Stand-by Arrangement}

The Executive Board of the International Monetary Fund (IMF) completed today the fifth review under the SDR 2.13 billion (US\$3.1 billion) Stand-By Arrangement (SBA) for Uruguay. Completion of the review makes SDR 139.8 million (about US\$204 million) immediately available to Uruguay. In completing the review, the Board granted waivers of nonobservance of two structural performance criteria on banking sector reforms and waivers of applicability of end-June 2004 performance criteria, for which data was not available, on the public sector primary balance and the nonfinancial public sector gross debt.

Furthermore, upon request by Uruguay in view of the improvement in Uruguay's economic outlook and external position, the remaining access under the SBA was reduced by SDR 139.8 million. Further disbursements under the SBA will be rephased in two equal installments of SDR 139.8 million each (about US\$204 million) that will become available following the completion of Executive Board reviews expected in November 2004, and February 2005.

The SBA was approved on March 25, 2002 in an amount of SDR 594.1 million (about US\$867 million) for a 24-month period (see Press Release No. 02/14). The SBA was augmented by SDR 1.16 billion (about US\$1.7 billion) on June 25, 2002 (see News Brief. No. 2 54), and by SDR 376 million (about US\$549 million) on August 8, 2002 (see News Brief. No. 02/87). Total commited resources under the Stand-By Arrangement now amount to SDR 1.99 billion (US\$2.9 billion) taking into account the recently approved reduction in access.

In commenting on the Executive Board decision, Agustín Carstens, Deputy Managing Director and Acting Chair, said:

“Uruguay's performance under the Stand-By Arrangement continues to be strong. The ongoing economic recovery has been faster than expected, reflecting implementation of prudent policies and a favorable external environment. Unemployment is down, financial indicators continue to improve, and the economic outlook for the remainder of 2004 and 2005 is encouraging. Consolidating the stabilization gains and sustaining the recovery will require continued implementation of sound policies, especially in the fiscal and bank restructuring areas, and policy continuity during the upcoming election period. 
“The authorities' commitment to a higher primary surplus target for 2004 is welcome, and will help enhance prospects for debt sustainability. To ensure that the target for this year will be met, primary spending will need to be kept within the program limits, tax revenue maintained, and public tariffs adjusted in a timely manner in line with cost developments. To bolster fiscal prospects over the medium term, revenue administration and the institutional framework for the budget will need to be strengthened, and pending reforms of the tax system and specialized pension funds implemented. The authorities are seeking consensus in support of the adoption of these essential reforms.

"Monetary policy has been appropriately tightened in recent months to ensure that inflation returns within the target band. The authorities' intention to raise the net international reserves target for 2004 will lock in part of the overperformance on the reserves front achieved in the first half of the year.

"Good progress is being made in restructuring the public financial institutions. BROU's strategic and operational reforms are proceeding as planned, and the BHU is reforming its operations with World Bank support. The process of asset disposal of three liquidated banks is now moving forward. Additional relief to bondholders and large depositors of the liquidated banks needs to be avoided.

"The authorities are committed to maintaining the policy framework through the upcoming election period, and recognize that there is no room for slippages. Attaining the program's objectives will be critical for sustained growth, financial stability, and public debt sustainability," Mr. Carstens said. 


\section{Statement by Guillermo Le Fort, Executive Director for Uruguay and David Vogel, Senior Advisor to Executive Director \\ August 27, 2004}

\section{Key points}

- Uruguay's commitment to macroeconomic stability and sound growth, demonstrated through decisive measures, have resulted in a strong economic recovery and the upturn of financial indicators.

- Exports continue to grow vigorously, while private investment shows an impressive recovery.

- Labor market conditions have improved significantly. The unemployment rate has fallen from about 20 percent to 13 percent in a year and a half.

- The authorities' effort to ensure public debt sustainability is mirrored in the new primary surplus target established for 2004 of 3.4 percent of GDP.

- $\quad$ The restructure of the BROU and BHU presents significant progress, while sustained progress is being made for a successful completion of the process of crisis resolution by the disposition of nonperforming assets in liquidation funds.

\section{Background}

1. The Uruguayan economy continues making substantial progress in its transition from the deepest financial crisis in its history to a path of sustainable growth. The strong economic recovery and the upturn of financial indicators, including the improved indicators of financial and banking sector soundness, and the upgrade by Fitch and S\&P of Uruguay's foreign currency debt rating are clear signs of this process. The Uruguayan authorities are fully aware that much remains to be done and, in general, they share the staff's comments that progress with structural reforms is still uneven. Nonetheless, it is necessary to keep in mind that over the past two years urgent measures have taken priority over other important ones. During this process, the authorities' commitment to macroeconomic stability has been demonstrated by the significant measures taken and the rapid and effective progress obtained.

2. During the first half of this year, the Uruguayan economy has continued its strong recovery, while inflation remains subdued and the fiscal accounts show further improvements. According to the latest data, economic activity picked up about 14 percent in the first quarter of 2004, compared to the same period in the previous year. The authorities' current projections for 2004 are indicating a robust GDP growth of more than 7 percent, substantially above the projected 5 percent presented last February in the fourth program review. 
3. Exports continue to be the main engine of the recovery, growing 32 percent in dollar terms in January-July of this year, compared to the same period in 2003. Moreover, they are becoming increasingly diversified in terms of both external markets and the country's export base. Exports to the U.S. now represent the largest share of the Uruguayan total external sales, while exports to Europe are currently in line with those to Mercosur countries, whose share has halved compared to that of four years ago. The authorities have continued making substantial progress towards integrating the country in the global economy. Furthermore, significant developments in infrastructure already underway -e.g. seaports- will be critical to support external sales.

4. Recovery is becoming more broadly based. Private consumption is picking up strongly, to the extent that the negative wealth effect has been substantially alleviated and credit restrictions are receding. In contrast to prior years, private investment has been growing vigorously in 2004, underlining the higher capacity utilization brought about by the recovery, as well as the interest of foreign investors in non-traditional sectors. Imports in machinery and equipment from the private sector increased about 100 percent in dollar terms in January-July 2004 as compared to the same period last year. Meanwhile, a bilateral investment treaty with Finland was ratified in May, and another treaty with the United States will be signed in a few weeks, which will complement the general framework that protects national and foreign investment. Moreover, the free trade agreement with Mexico, that includes a chapter on bilateral foreign investment, was also ratified in May.

5. The recovery has led to substantial improvements in labor market conditions with the unemployment rate falling from a peak of almost 20 percent in a year and a half, to 13.1 percent in April-June 2004. This is the lowest point in four years, while the average period of joblessness has fallen to half of what it was one year ago. Given the increased labor force participation, unemployment reduction is the result of a significant boost in employment.

\section{Macroeconomic Policies and Structural Reforms}

6. The authorities are fully committed to ensure the sustainability of public sector debt. They have increased the primary surplus target for 2004 from 3.2 percent to 3.4 percent of GDP. Moreover, under conservative assumptions, the authorities project for 2005 a primary surplus of the order of 3.7 to 3.9 percent of GDP. This reflects expenditure restraint, state enterprise tariffs adjusted in line with cost conditions, and robust revenue performance. Meanwhile, the authorities eliminated emergency surcharges and taxes introduced during the financial crisis. Given the distortive effects that these surcharges and taxes had on the supply side of the economy, the authorities considered that this decision would reinforce the economic recovery underway, thus partly offsetting the negative effects that this reduction might have on revenue performance. As noted in the staff report, the authorities have underscored that no further tax reduction will take place during this administration, while they have established a ceiling for discretional expenditures. The Uruguayan authorities consider that their expenditure plan and the current tax structure are consistent with the envisaged primary surplus targets for 2005. Tax revenue performance has been better than expected mainly due to the economic recovery and progress in modernizing the tax administration. In that vein, the government continues working for Parliament's passage of a regulation that would allow the restructuring of the Tax Administration Department (DGI). 
7. The Central Bank has pursued a prudent monetary policy, tightening the base money target as soon as inflation expectations increased above the Central Bank's inflation target range. Furthermore, given the new scenario for international interest rates and the uncertainty that elections often generate, as well as the lower inflation target range of 6-8 percent for 12month inflation through June 2005, the Central Bank set up a more tightened base money target range for the second half of the year, compared to that established earlier under the current program. At the same time, the authorities increased the program target on net international reserve accumulation for 2004 from US\$ 100 million to US\$ 180 million.

8. Another important objective of the Central Bank is related to favoring financial intermediation in domestic currency and a gradual and voluntary de-dollarization of the financial system. To attain that objective, the Central Bank has taken some measures, including a reduction in the reserve requirements for peso deposits and the introduction of inflation-indexed notes and bonds. However, it is clear that dollarization often has significant cultural roots, which is why the de-dollarization process takes time. Confidence on monetary policy and institutional framework is critical and, among other things, the authorities are committed to continue improving the financial safety net. In this regard, the authorities are analyzing the introduction of a limited deposit insurance scheme.

9. Critical progress has taken place in the BROU's restructuring process aimed at addressing the balance sheet problems of the bank as well as reducing high operating costs. Meanwhile, interest rates on remaining reprogrammed deposits were reduced from 6 percent to 3.5 percent, thus improving BROU's net operational earnings. Consequently, profits are exceeding the business plan, and operational costs are lower than programmed. It is also important to note that cash recoveries from NPLs through June already exceeded the 2004 target. Meanwhile, the release of the second tranche of reprogrammed deposits have yield positive results, with about 95 percent of deposits remaining in BROU. Moreover, as noted in the staff report, the World Bank staff reports good progress in restructuring the State mortgage company (BHU).

10. The Uruguayan authorities are making firm decisions for a successful bank resolution process, which, as noted in the staff report, represents a break with past practices of socializing losses. In that vein, they have faced significant obstacles posed by pressure groups, including labor unions and debtors of the liquidated banks. Meanwhile, substantial efforts have been made to minimize governance risks, having taken the needed actions to address them, including those concerned with prior actions for this review, as noted in paragraph 19 of the staff report. In particular, through a transparent bidding process, the Central Bank contracted a firm to manage the assets in the liquidation funds, establishing a mechanism that allows conciliating the firm's and fund creditors' incentives.

11. Consequently, the Uruguayan economy is on the way to taking full advantage of its solid institutions and consolidated democracy. Indeed, according to Latinobarómetro's last survey, Uruguay is the country in the region with the largest share of its population supporting its democratic system. At the same time, Uruguay shows the largest share of people holding the government as the main responsible for the people's welfare, and one of the smallest proportion considering that private enterprises are critical for development. The 
authorities have taken substantial actions to respond to these beliefs. While protecting the most vulnerable groups, the authorities have focused a good part of their efforts to avoid perverse incentives, increase transparency and competition, respect property rights, and make the rules of the game more predictable, as the only way to promote private investment and entrepreneurship and, thus, development. 